\title{
WestVirginiaUniversity
}

THE RESEARCH REPOSITORY @ WVU

Graduate Theses, Dissertations, and Problem Reports

2013

\section{Hydrologic Response of Alternative Valley Fill Reclamation Designs}

\author{
Michael W. Snyder \\ West Virginia University
}

Follow this and additional works at: https://researchrepository.wvu.edu/etd

\section{Recommended Citation}

Snyder, Michael W., "Hydrologic Response of Alternative Valley Fill Reclamation Designs" (2013). Graduate Theses, Dissertations, and Problem Reports. 399.

https://researchrepository.wvu.edu/etd/399

This Thesis is protected by copyright and/or related rights. It has been brought to you by the The Research Repository @ WVU with permission from the rights-holder(s). You are free to use this Thesis in any way that is permitted by the copyright and related rights legislation that applies to your use. For other uses you must obtain permission from the rights-holder(s) directly, unless additional rights are indicated by a Creative Commons license in the record and/ or on the work itself. This Thesis has been accepted for inclusion in WVU Graduate Theses, Dissertations, and Problem Reports collection by an authorized administrator of The Research Repository @ WVU. For more information, please contact researchrepository@mail.wvu.edu. 
Hydrologic Response of Alternative Valley Fill Reclamation Designs Michael W. Snyder

Thesis submitted to the

Benjamin M. Statler College of Engineering and Mineral Resources at West Virginia University in partial fulfillment of the requirements for the degree of

\author{
Master of Science \\ In \\ Civil Engineering
}

Dr. Leslie C. Hopkinson, Ph.D., Chair

Dr. John D. Quaranta, Ph.D.

Benjamin Mack

Department of Civil and Environmental Engineering

Morgantown, West Virginia

2013

Keywords: valley fill, surface runoff, modeling, geomorphic, AOC Copyright 2013, Michael W. Snyder 


\title{
Abstract \\ Hydrologic Response of Alternative Valley Fill Reclamation Designs
}

\author{
Michael W. Snyder
}

Mountaintop mining (MTM) is a widely practiced surface mining technique in Central Appalachia. Conventional reclamation (Approximate Original Contour), involves the construction of valley fills in headwater systems. Recent research suggests that current MTM reclamation techniques increase stormflow response of the affected watersheds when compared to the original, undisturbed conditions. One method that has shown success in reclaiming surface mine sites in semi-arid regions of the western U.S. is geomorphic landform design. Geomorphic reclamation is based upon creating landforms that resemble the mature surrounding watersheds in both topography and hydrologic response. The objective of this research was to predict the hydrologic response of a mine site reclaimed using geomorphic methods for a location in southern West Virginia. Three alternative geomorphic reclamation designs were modeled using Aquaveo's Watershed Modeling System: i) a geomorphic reclamation of the valley fill; ii) a geomorphic reclamation of the valley fill with three detention ponds; and, iii) a geomorphic retrofit design. Results were compared to the response of both the original, undisturbed topography and a conventional valley fill. The peak flowrate, time to peak, and runoff volumes were evaluated at three stages of reclamation (during mining, post-mining ( $<5$ years), and post-mining ( $>5$ years)) for a range of storm events (1- through 500-year, 24-hour). The hydrologic response of the geomorphic landform design without detention ponds most closely resembled the values obtained for the original watershed. The geomorphic design with detention ponds lowered the peak flowrate, time of peak, and total runoff volume below the values generated by the original watershed. The runoff storage within the detention ponds provides the potential to allow stream flow in excess of ephemeral conditions. However, the ponds need to be properly sized to allow greater runoff storage if intermittent or perennial stream flow is desired. The effectiveness of the retrofit reclamation design was difficult to determine due to changes in watershed area and drainage pattern. These results indicate that geomorphic landform designs could be used to recreate the approximate hydrologic response of the original watershed for reclaimed mountaintop mine sites in southern West Virginia watersheds. 


\section{Acknowledgments}

The project described in this publication was supported by Grant/Cooperative Agreement Number G12AP20156 from the United States Geological Survey. Its contents are solely the responsibility of the authors and do not necessarily represent the official views of the USGS.

I would like to thank my advisor, Dr. Leslie Hopkinson, for all of her guidance and assistance in completing this research project. Her help and support were instrumental in my completion of this research and taught me innumerable lessons about research, writing, and much more. I would like to thank both Dr. John Quaranta and Benjamin Mack for giving their time to join the committee.

I would like to thank Ms. Allison Sears for the development of the geomorphic landform reclamation designs used for my hydrologic modeling.

I would like to dedicate this thesis to my family and my wife, who have supported me throughout this entire process. 


\section{Table of Contents}

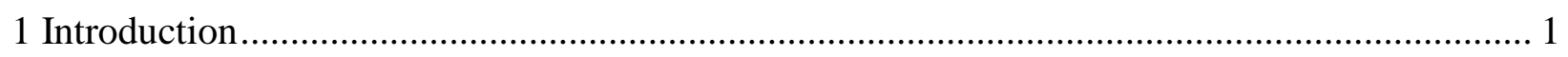

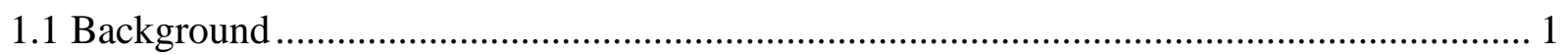

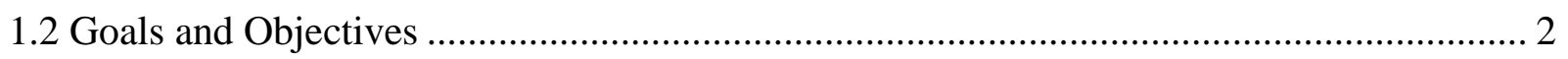

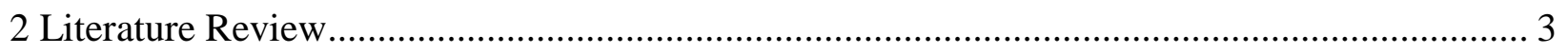

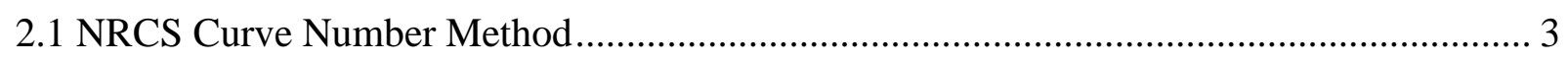

2.2 Kirpich Method for Overland Flow …………………..................................................... 5

2.3 Technical Release 20 ................................................................................................... 5

2.3.1 Muskingum-Cunge Routing Method ........................................................................ 6

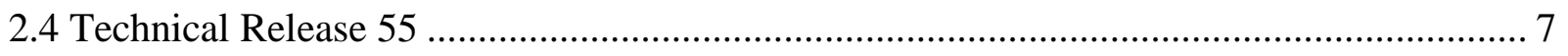

2.5 Geomorphic Landform Design ....................................................................................... 7

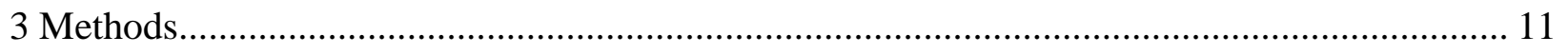

3.1 Curve Number (CN) Calculation ............................................................................ 11

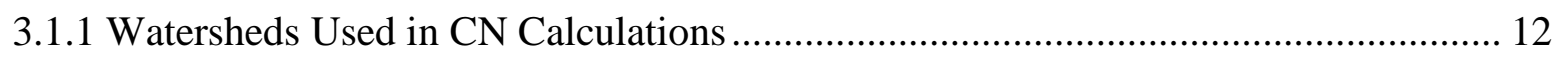

3.1.2 Percent Mining Calculations ..................................................................................... 13

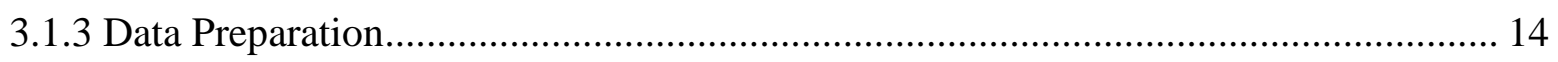

3.1.4 Curve Number Calculation ................................................................................... 16

3.2 Modeling ................................................................................................................ 17

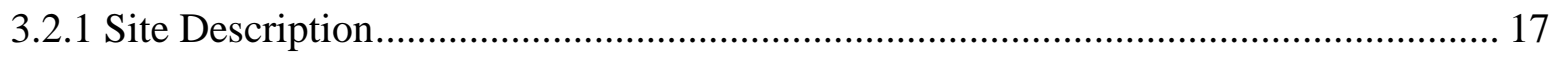

3.2.2 Hydrologic Modeling........................................................................................... 18

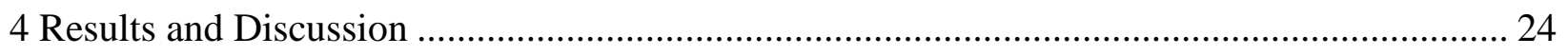

4.1 Curve Number Results.............................................................................................. 24

4.2 Hydrologic Modeling.................................................................................................. 24

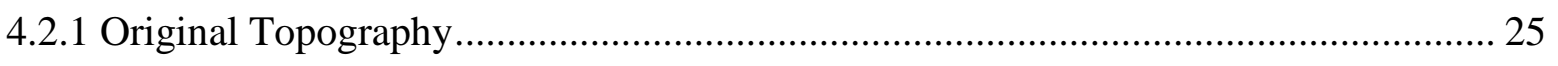

4.2.2 Approximate Original Contour Variance......................................................................... 29

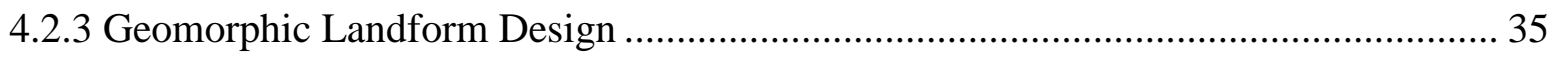

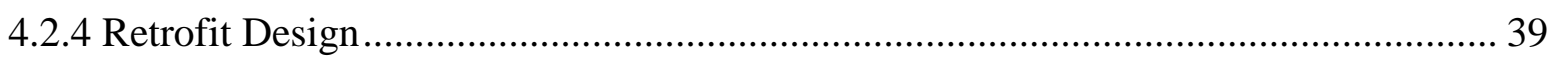

4.2.5 Detention Pond Design ............................................................................................. 45

4.3 Comparison of Reclamation Designs............................................................................. 49

4.3.1 Comparison of Reclamation Designs to the Original Topography at $\mathrm{CN}=66$........... 49

4.3.2 Comparison of the Reclamation Designs to the Original Topography at $\mathrm{CN}=84 \ldots . .59$ 
4.3.3 Comparison of GLD reclamation to conventional reclamation .................................... 68

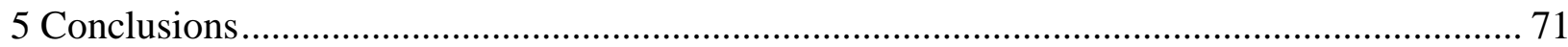

5.1 Study Limitations and Future Research ............................................................................ 72

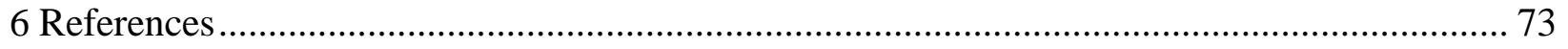

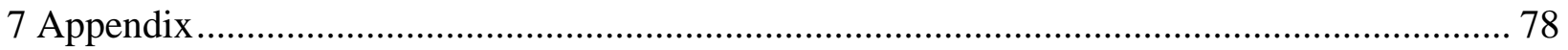

Appendix A: Storm Response Hydrographs...................................................................... 78

Appendix B: Percent Difference Between Reclamation Designs and Original Topography for

1 through 500-year Return Periods ........................................................................................ 90 


\section{Table of Figures}

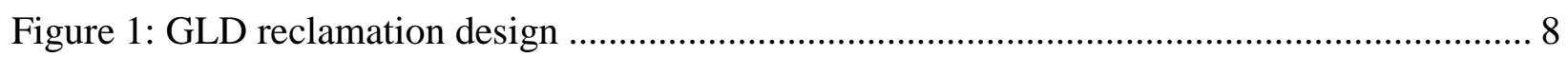

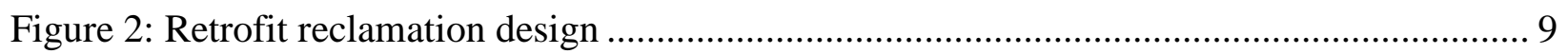

Figure 3: Detention basin reclamation design with detention basins outlined in yellow ............. 10 Figure 4: Location of watersheds used in CN calculations: Panther Creek, Clear Fork, and Laurel

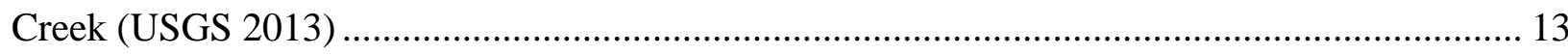

Figure 5: The Clear Fork watershed with satellite imagery used in percent mining calculation.. 14 Figure 6: Trimmed NOAA precipitation data layer over top of watershed shape......................... 15

Figure 7: Trimmed NOAA precipitation data layer with the area of effect overlay...................... 15

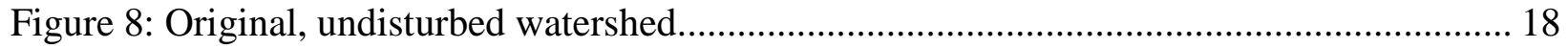

Figure 9: Original topography delineated watershed and watershed sub-basins .......................... 25

Figure 10: Storm response hydrograph for a 2-year storm at outlet 1C of original topography for varying CN................................................................................................................... 29

Figure 11: Post-mining map used in SEDCAD modeling (clipped to highlight watershed being

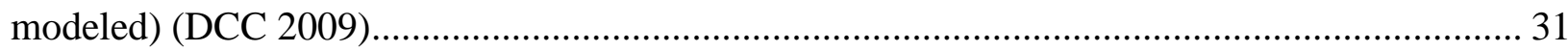

Figure 12: Revised post-mining map used in WMS modeling (clipped to highlight watershed being modeled) Note: Red line added near watershed outlet for illustrative purposes. ................ 31

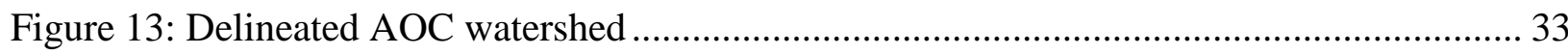

Figure 14: GLD topography delineated watershed and watershed sub-basins .............................. 36

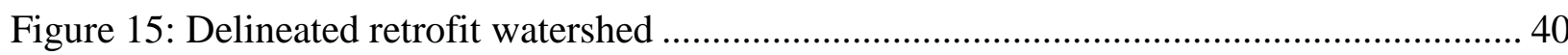

Figure 16: Designed watershed with detention pond sub-basins delineated .................................. 45 Figure 17: Storm response hydrograph for a 1-year storm at outlet 1C of original topography for

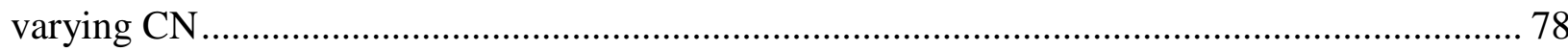

Figure 18: Storm response hydrograph for a 5-year storm at outlet 1C of original topography for

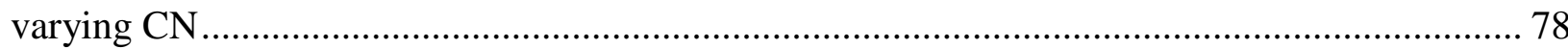

Figure 19: Storm response hydrograph for a 10-year storm at outlet 1C of original topography for

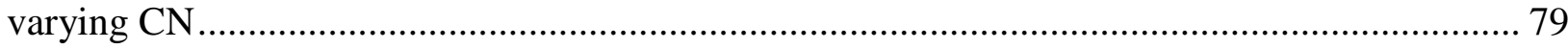

Figure 20: Storm response hydrograph for a 25-year storm at outlet 1C of original topography for

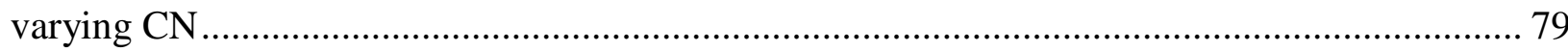

Figure 21: Storm response hydrograph for a 50-year storm at outlet $1 \mathrm{C}$ of original topography for

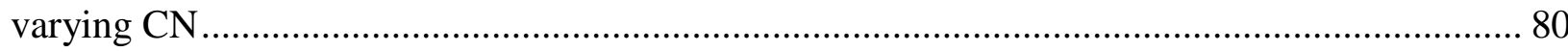

Figure 22: Storm response hydrograph for a 100 -year storm at outlet $1 \mathrm{C}$ of original topography for varying $\mathrm{CN}$................................................................................................................ 80

Figure 23: Storm response hydrograph for a 500-year storm at outlet 1C of original topography

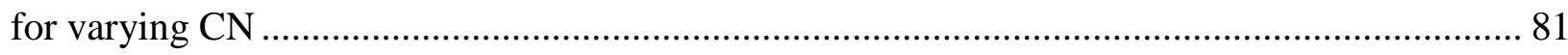

Figure 24: Storm response hydrograph for a 1-year storm at outlet 1C of detention pond design

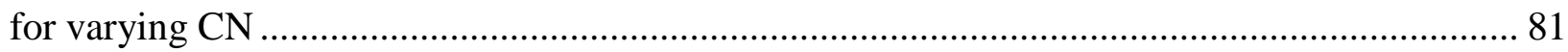
Figure 25: Storm response hydrograph for a 2-year storm at outlet 1C of detention pond design

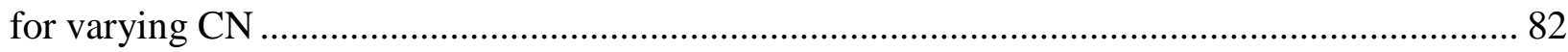


Figure 26: Storm response hydrograph for a 5-year storm at outlet 1C of detention pond design

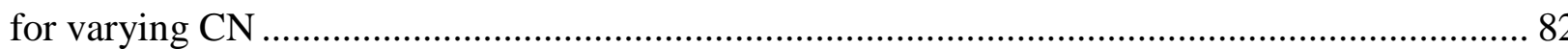

Figure 27: Storm response hydrograph for a 10-year storm at outlet 1C of detention pond design for varying $\mathrm{CN}$ 83 Figure 28: Storm response hydrograph for a 25-year storm at outlet 1C of detention pond design for varying $\mathrm{CN}$ 83 Figure 29: Storm response hydrograph for a 50-year storm at outlet 1C of detention pond design for varying $\mathrm{CN}$ 84 Figure 30: Storm response hydrograph for a 100-year storm at outlet 1C of detention pond design

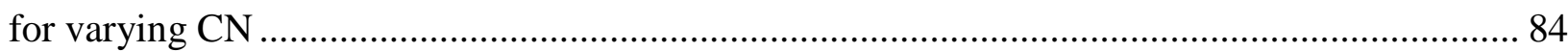
Figure 31: Storm response hydrograph for a 500-year storm at outlet $1 \mathrm{C}$ of detention pond design

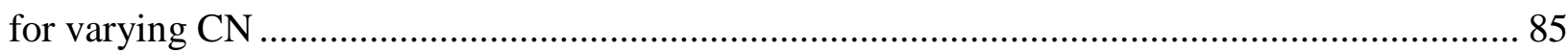
Figure 32: Storm response hydrograph for a 1-year storm at outlet 1C of retrofit design for varying CN. 85

Figure 33: Storm response hydrograph for a 2-year storm at outlet 1C of retrofit design for varying $\mathrm{CN}$ 86

Figure 34: Storm response hydrograph for a 5-year storm at outlet 1C of retrofit design for varying $\mathrm{CN}$ 86 Figure 35: Storm response hydrograph for a 10-year storm at outlet 1C of retrofit design for varying $\mathrm{CN}$. 87

Figure 36: Storm response hydrograph for a 25-year storm at outlet 1C of retrofit design for varying $\mathrm{CN}$

Figure 37: Storm response hydrograph for a 50-year storm at outlet 1C of retrofit design for varying $\mathrm{CN}$ 88

Figure 38: Storm response hydrograph for a 100-year storm at outlet 1C of retrofit design for varying $\mathrm{CN}$ 88

Figure 39: Storm response hydrograph for a 500-year storm at outlet $1 \mathrm{C}$ of retrofit design for varying $\mathrm{CN}$ 


\section{Table of Tables}

Table 1: Calculated CNs for reclaimed surface mine sites ...................................................... 5

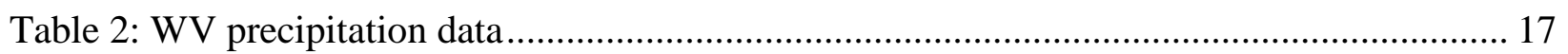

Table 3: CN values used to model hydrologic response of alternative reclamation designs under

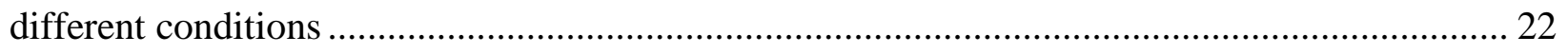

Table 4: Calculated CN values for three watersheds in southern WV .................................... 24

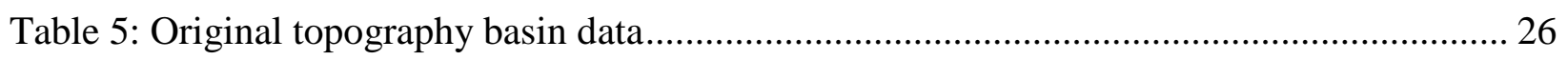

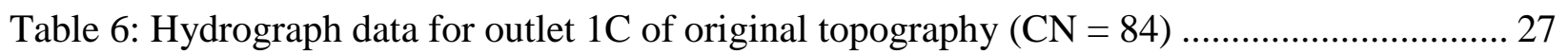

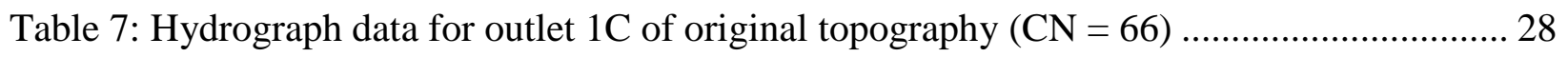

Table 8: Hydrograph data for outlet 1C of AOC variance...................................................... 30

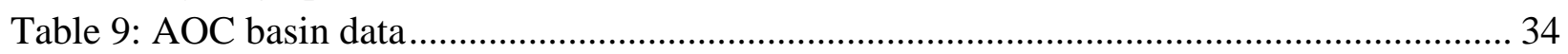

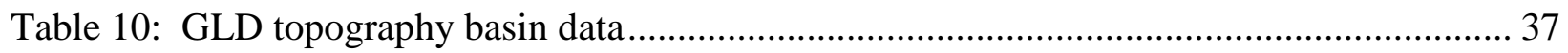

Table 11: Hydrograph data for outlet $1 \mathrm{C}$ of GLD topography during mining $(\mathrm{CN}=84)$............. 38

Table 12: Hydrograph data for outlet $1 \mathrm{C}$ of GLD topography for post-mining conditions $(\mathrm{CN}=$

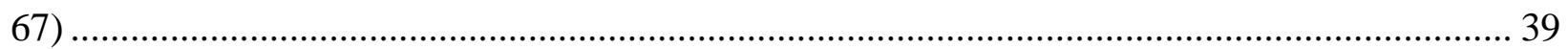

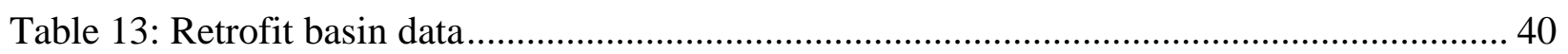

Table 14: Hydrograph Data for retrofit design for during-mining conditions $(\mathrm{CN}=84)$............. 42

Table 15: Hydrograph Data for retrofit design for short-term post-mining conditions (CN=67) 43

Table 16: Hydrograph Data for retrofit design for long-term post-mining conditions ( $\mathrm{CN}=60)$. 44

Table 17: Detention pond watershed data acquired from WMS............................................ 46

Table 18: Hydrograph data for the designed watershed during mining $(\mathrm{CN}=84)$................... 47

Table 19: Hydrograph data for the outlet of the designed watershed for short-term post-mining

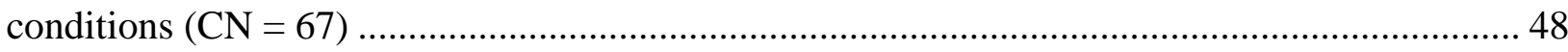

Table 20: Hydrograph data for the outlet of the designed watershed for long-term post-mining

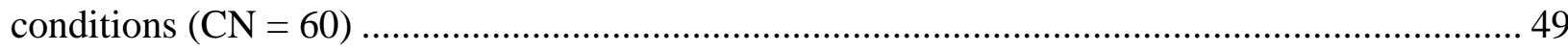

Table 21: Comparison between the hydrologic response of the GLD watershed $(\mathrm{CN}=84)$ and the original topography for during mining conditions.............................................................. 50

Table 22: Comparison between the hydrologic response of the GLD watershed $(\mathrm{CN}=67)$ and the original topography for post-mining conditions .............................................................. 51

Table 23: Comparison between the hydrologic response of the designed watershed $(\mathrm{CN}=84)$ and original topography for during mining conditions ................................................... 52 Table 24: Comparison between the hydrologic response of the designed watershed $(\mathrm{CN}=67)$ and original topography for short-term, post-mining conditions ........................................... 53 Table 25: Comparison between the hydrologic response of the designed watershed $(\mathrm{CN}=60)$ and original topography for long-term, post-mining conditions............................................ 54 Table 26: Comparison between the hydrologic response of 2B of the retrofit watershed $(\mathrm{CN}=84)$ and original topography for during mining conditions ........................................................ 55 Table 27: Comparison between the hydrologic response of 2B of the retrofit watershed $(\mathrm{CN}=67)$ and original topography for post-mining, short-term conditions 56 
Table 28: Comparison between the hydrologic response of $2 \mathrm{~B}$ of the retrofit watershed $(\mathrm{CN}=60)$ and original topography for post-mining, long-term conditions. 57

Table 29: Average percent difference between original topography at $\mathrm{CN}=66$ and various reclamation designs for peak discharge, time of peak, and total runoff averaged over all rainfall return periods . 58 Table 30: Comparison between the hydrologic response of the GLD watershed $(\mathrm{CN}=84)$ and the

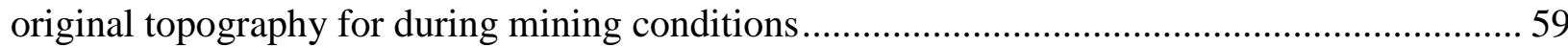
Table 31: Comparison between the hydrologic response of the GLD watershed $(\mathrm{CN}=67)$ and the original topography for post-mining conditions .... 60

Table 32: Comparison between the hydrologic response of the designed watershed $(\mathrm{CN}=84)$ and original topography for during mining conditions. 61

Table 33: Comparison between the hydrologic response of the designed watershed $(\mathrm{CN}=67)$ and original topography for short-term, post-mining conditions 62 Table 34: Comparison between the hydrologic response of the designed watershed $(\mathrm{CN}=60)$ and original topography for long-term, post-mining conditions. 63 Table 35: Comparison between the hydrologic response of $2 \mathrm{~B}$ of the retrofit watershed $(\mathrm{CN}=84)$ and original topography for during mining conditions Table 36: Comparison between the hydrologic response of $2 \mathrm{~B}$ of the retrofit watershed $(\mathrm{CN}=67)$ and original topography for post-mining, short-term conditions 65 Table 37: Comparison between the hydrologic response of 2B of the retrofit watershed $(\mathrm{CN}=60)$ and original topography for post-mining, long-term conditions. 66

Table 38: Average percent difference between original topography at $\mathrm{CN}=84$ and various reclamation designs for peak discharge, time of peak, and total runoff averaged over all rainfall return periods

Table 39: Percent difference of peak discharge in comparison with the conventional reclamation

Table 40: Percent difference of time of peak in comparison with the conventional reclamation 70 Table 41: Percent difference of peak discharge in comparison with the original topography at CN $=66$ 90

Table 42: Percent difference of time of peak in comparison with the original topography at $\mathrm{CN}=$ 66.

Table 43: Percent difference of total runoff volume in comparison with the original topography at $\mathrm{CN}=66$.

Table 44: Percent difference of peak discharge in comparison with the original topography at CN $=84$

Table 45: Percent difference of time of peak in comparison with the original topography at $\mathrm{CN}=$ 84.

Table 46: Percent difference of total runoff volume in comparison with the original topography at $\mathrm{CN}=84$ 


\section{Introduction}

\subsection{Background}

Mountaintop mining (MTM) is a surface mining technique that involves the removal of rock and soil on mountain tops to expose underlying coal seams. Once the rock and soil, or spoil, is removed the coal is then extracted (EPA 2013). Once all of the coal has been extracted, the mine site is reclaimed in accordance with Approximate Original Contour (AOC). AOC reclamation uses the spoil to reconstruct the approximate contours of the mountain (EPA 2013). Excess spoil not used in the AOC reclamation is placed into nearby valleys to create what is known as a valley fill (VF) (Fritz et al. 2010). Although AOC reclamation and VF construction are regulated by the Clean Water Act as well as the Surface Mining Control and Reclamation Act (SMCRA), concerns about the environmental impact of the reclamation technique and the longterm stability of VFs have been raised (EPA 2013; Fritz et al. 2010; McGarvey and Johnston 2012). Negley and Eshleman (2006) found that the alterations in topography caused by MTM/VF processes promoted increased runoff by overland flow, resulting in increased storm runoff volumes and increased frequency and magnitude of downstream flooding (McCormick et al. 2009; Ferrari et al. 2009).

A reclamation technique known as geomorphic landform design (GLD) has been used with success to reclaim surface mines in semi-arid regions (Martin-Duque et al. 2009; MartinMoreno et al. 2008) and may help mitigate these hydrologic impacts. GLD aims to create landforms that are in a steady-state condition of dynamic equilibrium where erosive and resistance forces are in balance (Bugosh 2009). A watershed that is in dynamic equilibrium requires less long-term maintenance, fewer man-made control structures, and supports long-term landform stability (Martin-Duque et al. 2009). Modeling results of GLD reclamation on VF sites suggest that this technique can reduce peak flow rates by more than $90 \%$, total runoff volumes by 30\%, and total sediment load by 50\% (Warner et al. 2009). This approach has been identified by the US Office of Surface Mining, Reclamation and Enforcement as having many long-term benefits and successfully resisting major erosion (OSMRE 2009). GLD reclamation practices have not yet been implemented at West Virginia mine sites. The focus of this study is to investigate the surface water hydrology of potential GLD reclamation designs for a mine site in southern West Virginia. 


\subsection{Goals and Objectives}

The goal of this research is to investigate the use of geomorphic landform design reclamation techniques within the Central Appalachian region. The specific objective of this research was to determine the hydrologic response of three alternative reclamation designs at a permitted site in southern West Virginia that were created using geomorphic landform design principles. The hydrologic responses of the re-designed conditions were compared to the response of the original topography and to the response of a conventional valley fill. Extreme hydro-meteorological events (500-year storm events) were considered. 


\section{Literature Review}

This literature review will provide a brief overview of the tools used for the hydrologic modeling. Geomorphic landform design principles will also be introduced.

\subsection{NRCS Curve Number Method}

The Natural Resources Conservation Science (NRCS) Curve Number (formerly SCS Curve Number) method is a tool used to provide a reasonable estimate on the conversion of return period rainfall into return period runoff. Originally used to estimate runoff for agricultural watersheds in the United States, it is now widely used in a wide variety of watersheds across America (Hawkins et al. 2002). The return period runoff is calculated using the following equation:

$$
Q=\frac{\left(P-I_{a}\right)^{2}}{\left(P-I_{a}\right)+S}
$$

where, $\mathrm{Q}=$ total runoff (in.); $\mathrm{P}=$ total rainfall (in.); $\mathrm{I}_{\mathrm{a}}=$ initial abstraction (in.); and $\mathrm{S}=$ potential maximum retention after runoff begins (in.) (Cronshey 1986). The variable $S$ is related to the curve number (CN) by the equation:

$$
S=\frac{1000}{C N}-10
$$

Equation 1 is valid when $P \geq I_{a}$. When $\mathrm{P} \leq \mathrm{I}_{\mathrm{a}}, \mathrm{Q}=0$. The initial abstraction variable includes all losses before runoff begins (e.g. water retention in surface depressions, water intercepted due to vegetation, evaporation, and infiltration into the soil). The value for the initial abstraction is commonly stated as $I_{a}=0.2 S$ to simplify calculations (Fennessey and Hawkins 2001). However, the simplification of the initial abstraction has recently been questioned with many stating that the value of $\lambda=0.2$ is useful only for agricultural watersheds (Maidment 1992; Woodward 2003).

The major determining factors for calculating the $\mathrm{CN}$ are the hydrologic soil group (HSG), cover type, treatment, hydrologic condition, and antecedent runoff condition (ARC) (formerly the antecedent moisture condition). HSGs are classified by four specific groups: A, B, $\mathrm{C}$, and D. The groups are ranked according to their minimum infiltration rates with A having the highest infiltration rate and D having the lowest (U.S. SCS 1985). 
Treatment is a cover type modifier and is used to describe agricultural land management techniques employed on a watershed that would affect the CN. Hydrologic condition is an indicator of the effects of cover type and treatment on the infiltration rate and runoff. Soil that has a low runoff potential has a hydrologic condition of "good." The antecedent runoff condition is an index of runoff potential and is used to account for variation in the $\mathrm{CN}$ at a particular watershed site from one storm event to another (Maidment 1992).

Due to the nature of the construction of valley-fills and the mixing of soil types that can occur, calculating the $\mathrm{CN}$ for a surface mine spoil site can be difficult. However, in a study of loose-dumped spoil in eastern Kentucky, Taylor found CNs for the Bent Mountain surface mine site in eastern Kentucky to be $60 \pm 16$ for rainfall events producing more than $25.4 \mathrm{~mm}$ of precipitation (Taylor et. al. 2009).

Since its introduction in the mid 1950's the Curve Number method has become a mainstay of hydrotechnical engineering and is considered to be a widely understood and accepted conceptual model to reflect rainfall-to-runoff conversions (Ponce and Hawkins 1996). However, the simplification of $\lambda=0.2$ is based on studies done on many small agricultural watersheds and should not be used outside of similar applications (Fennessey and Hawkins 2001). Woodward (2003) investigated the initial abstraction term of the CN method. Woodward (2003) suggested the use of $\lambda=0.05$ provided more accurate runoff estimates. For this project $\lambda=0.05$ will be used.

The use of the NRCS CN method on mining reclamation sites allows for estimates of runoff potential at the sites being studied. $\mathrm{CN}$ values have been calculated for reclaimed mine sites throughout Kentucky, Ohio, Maryland, and Pennsylvania (Bonta et al. 1997; McCormick and Eshleman 2011; Ritter and Gardner 1991; Taylor et al. 2009; Warner et al. 2010). The calculated curve numbers show much variability ranging from 60 to 97 (Table 1). 
Table 1: Calculated CNs for reclaimed surface mine sites

\begin{tabular}{ccc}
\hline Reference & Mining Location & Curve Number \\
\hline Bonta et al., 1997 & Ohio & $87-97$ \\
McCormick and Eshleman, 2011 & Maryland & $68-92$ \\
Ritter and Gardner, 1991 & Pennsylvania & $72-89$ \\
Talyor et al., 2009 & Kentucky & $60-90$ \\
Warner et al., 2010 & Kentucky & $62-94$ \\
\hline
\end{tabular}

\subsection{Kirpich Method for Overland Flow}

The time of concentration $\left(\mathrm{T}_{\mathrm{c}}\right)$ of a watershed is the time required for runoff to travel from the most hydraulically distant point to the outlet of a watershed (Kirpich 1940; NRCS 1972). The Kirpich method was first introduced by Phillip Zalman Kirpich as a viable method to calculate $T_{C}$ values for watersheds (Kirpich 1940). The equation to calculate $T_{c}$ was derived from data collected from seven agricultural watersheds in Tennessee ranging in size from 1.25 acres to 112.0 acres (Kirpich 1940). Though the method was developed using agricultural watersheds the method has proved effective at estimating $\mathrm{T}_{\mathrm{C}}$ values in both rural and urban watersheds (Fang et al. 2008).

\subsection{Technical Release 20}

Technical Release 20 (TR-20) is a program provided by the NRCS for modeling the hydrologic response of a watershed for a single rainfall event. WinTR-20 is an upgraded version of the TR-20 program from 1992 that was modified to operate with the Windows Interface and is now the hydrologic modeling program recommended for use by the NRCS and the Federal Emergency Management Agency (FEMA 2004). The WinTR-20 software includes updated computational coding and uses the Muskingum-Cunge method for reach routing in place of the Modified Attenuation-Kinematic routing model. The program is designed to provide assistance in evaluating the hydrologic impacts of flood events for water resource projects using hydrologic modeling techniques based upon the curve number method and unit hydrograph theory outlined in the National Engineering Handbook (National Engineering Handbook, Part 630, Hydrology, NEH-630.10 and 630.16). The minimum inputs required by the WinTR-20 program include unit designation, sub-basin drainage area, sub-basin CN, time of concentration, storm type and precipitation depth. WinTR-20 has the ability to model flow directed through natural or 
designed channels and flow directed through control structures such as detention basins and culverts (USDA 2004).

\subsubsection{Muskingum-Cunge Routing Method}

The Muskingum-Cunge routing method used within TR-20 is a modified version of the Muskingum routing method. The Muskingum-Cunge method is described by two equations, the first is the conservation of mass and the second is a relationship of storage, inflow, and outflow of the reach. The first equation is described below:

$$
\frac{I 1+I 2}{2} \Delta t-\frac{01+02}{2} \Delta t=S 2-S 1
$$

where, I1 and I2 = inflow discharges at time 1 and time $2\left(\mathrm{ft}^{3} / \mathrm{sec}\right), \mathrm{O} 1$ and $\mathrm{O} 2=$ outflow discharges at time 1 and time $2\left(\mathrm{ft}^{3} / \mathrm{sec}\right), \Delta \mathrm{t}=$ time difference between time 1 and time 2 (sec), and S1 and S2 = values of reach storage at time 1 and time $2\left(\mathrm{ft}^{3}\right)$. The second equation is described by:

$$
S=K(X I+(1-X) O)
$$

where, $\mathrm{S}=$ reach storage $\left(\mathrm{ft}^{3}\right), \mathrm{I}=$ inflow discharge $\left(\mathrm{ft}^{3} / \mathrm{sec}\right), \mathrm{O}=$ outflow discharge $\left(\mathrm{ft}^{3} / \mathrm{sec}\right), \mathrm{K}=$ storage constant (sec) and $\mathrm{X}=$ weighting factor (dimensionless). The Muskingum-Cunge method goes on to describe equations for $\mathrm{K}$ and $\mathrm{X}$ that are developed from the hydraulic properties of the reach. The equation for the weighting factor $\mathrm{X}$ is:

$$
X=\frac{1}{2}\left(1-\left(\frac{Q}{B S_{o} c \Delta x}\right)\right)
$$

where, $\mathrm{c}=$ flood wave celerity $(\mathrm{ft} / \mathrm{sec}), \Delta \mathrm{x}=$ distance increment $(\mathrm{ft}), \mathrm{B}=$ bottom width $(\mathrm{ft}), \mathrm{S}_{\mathrm{o}}=$ channel slope $(\mathrm{ft} / \mathrm{ft})$ and $\mathrm{Q}=$ flow rate $\left(\mathrm{ft}^{3} / \mathrm{sec}\right)$. $\mathrm{K}$ is calculated using the equation:

$$
K=\frac{\Delta x}{c}
$$

where, $\mathrm{c}=$ flood wave celerity (ft/sec) and $\Delta \mathrm{x}=$ distance increment (ft) (Merkel 2002). 


\subsection{Technical Release 55}

Technical Release 55 (TR-55) is a simplified version of TR-20 and is used to create a hydrologic model of single-event rainfall-runoff relationships in small watersheds. First issued by the Soil Conservation Service (SCS) in 1975 TR-55 was updated in 1986 and in 1998 the program was modernized to WinTR-55. WinTR-55 uses the WinTR-20 computational routine for creating, routing, and adding hydrographs and also uses the Muskingum-Cunge method for reach routing. While WinTR-20 has the capacity to handle very complex models WinTR-55 can model a maximum of 10 subwatersheds with no more than 10 reaches with an area of no more than 25 square miles. WinTR-55 control structure modeling is limited to pipe or weir structures (USDA 2009).

\subsection{Geomorphic Landform Design}

Geomorphic landform design is a surface mining reclamation technique that incorporates hydrologically mature landform shapes into the design to reduce post-reclamation erosion or sedimentation processes. This approach focuses upon the construction of landform shapes that are both in dynamic equilibrium and hydrologically similar to surrounding natural watersheds. Watersheds in dynamic equilibrium experience a balance between erosive and resistance forces that promotes low erosion rates, minimizes long-term maintenance and supports long-term stability of the constructed landforms (Martin-Duque et al. 2009).

Surface mine sites in semi-arid regions of the U.S. have been successfully reclaimed using geomorphic landform design principles (Measles and Bugosh 2007; Robson et al. 2009). Currently no surface mining sites in West Virginia have been reclaimed using geomorphic landform design concepts. A number of challenges are associated with the implementation of this reclamation approach in Central Appalachian mine sites including higher initial construction costs, reclamation regulations that are not "explicitly supportive" of geomorphic reclamation principles, and the issue of constructing mature and stable landforms in an environment that is naturally erosional (Michael et al. 2010).

This work builds upon previous work by Sears (2012), Sears et al. (2013) and Sears et al. (unpublished data) that developed three alternative designs for a permitted valley fill in southern West Virginia. The three designs evaluated in this study are described in the following paragraphs. 


\section{$\underline{\text { Geometric Landform Design }}$}

The first geomorphic reclamation design incorporated geomorphic landform design techniques to reclaim the mine site. Instead of control structures and drainage ditches the design created sub-basins that directed flow to pre-established stream beds. These stream beds carry runoff to the original stream. The sub-basins were designed in such a way as to capture and channel enough precipitation to prevent sedimentation processes, but not so much precipitation that the runoff erodes the designed stream beds (Figure 1).

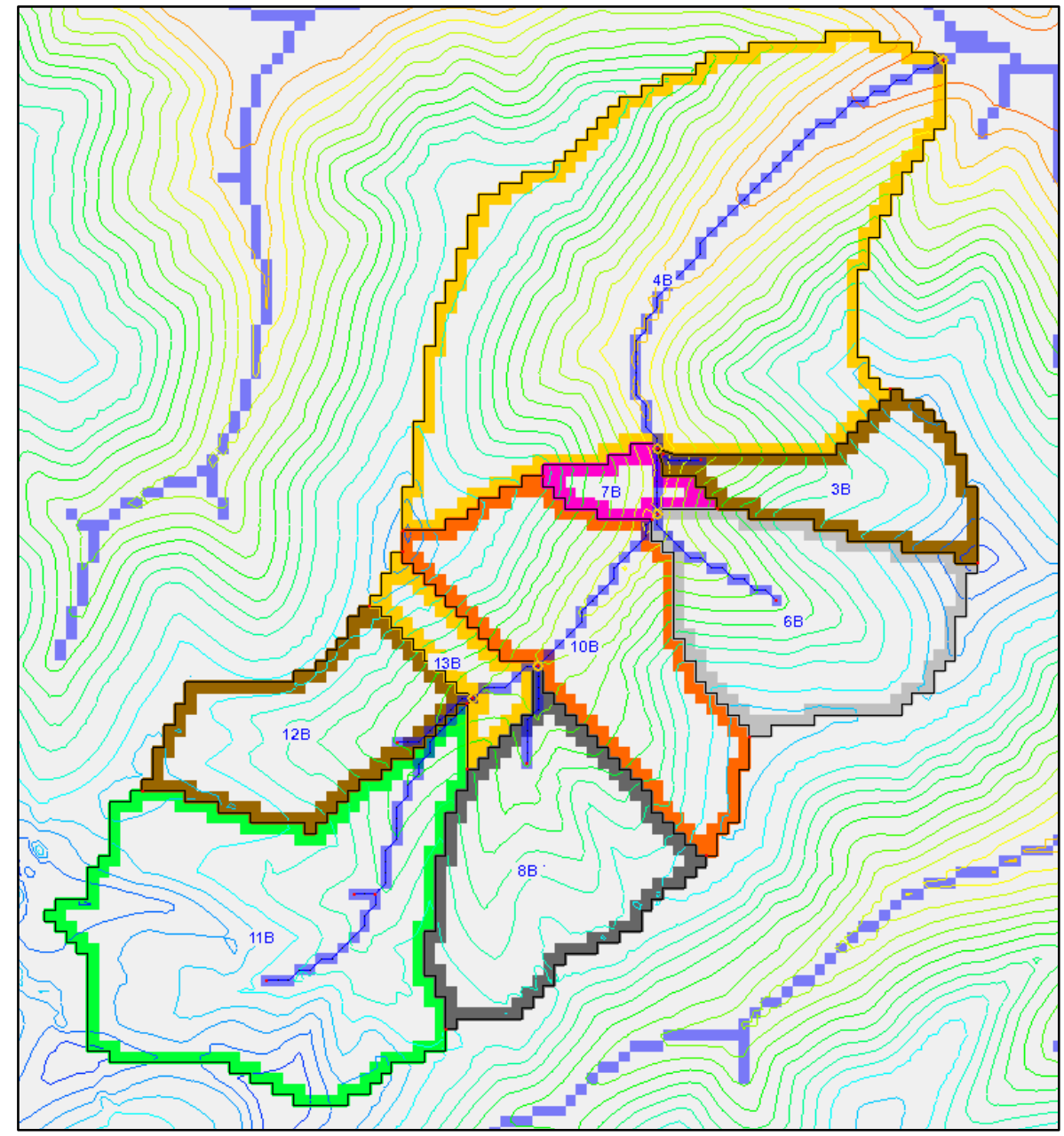

Figure 1: GLD reclamation design 


\section{$\underline{\text { Retrofit }}$}

The second design is a retrofit reclamation based upon geomorphic landform design principles. The design is positioned on top of the AOC variance reclamation design after the variance reclamation has been completed. Four new sub-basins were created that will direct flow to four separate tributaries (Figure 2). The design is assumed to be constructed using loosely dumped spoil and be formed into the sub-basins as depicted in Figure 2.

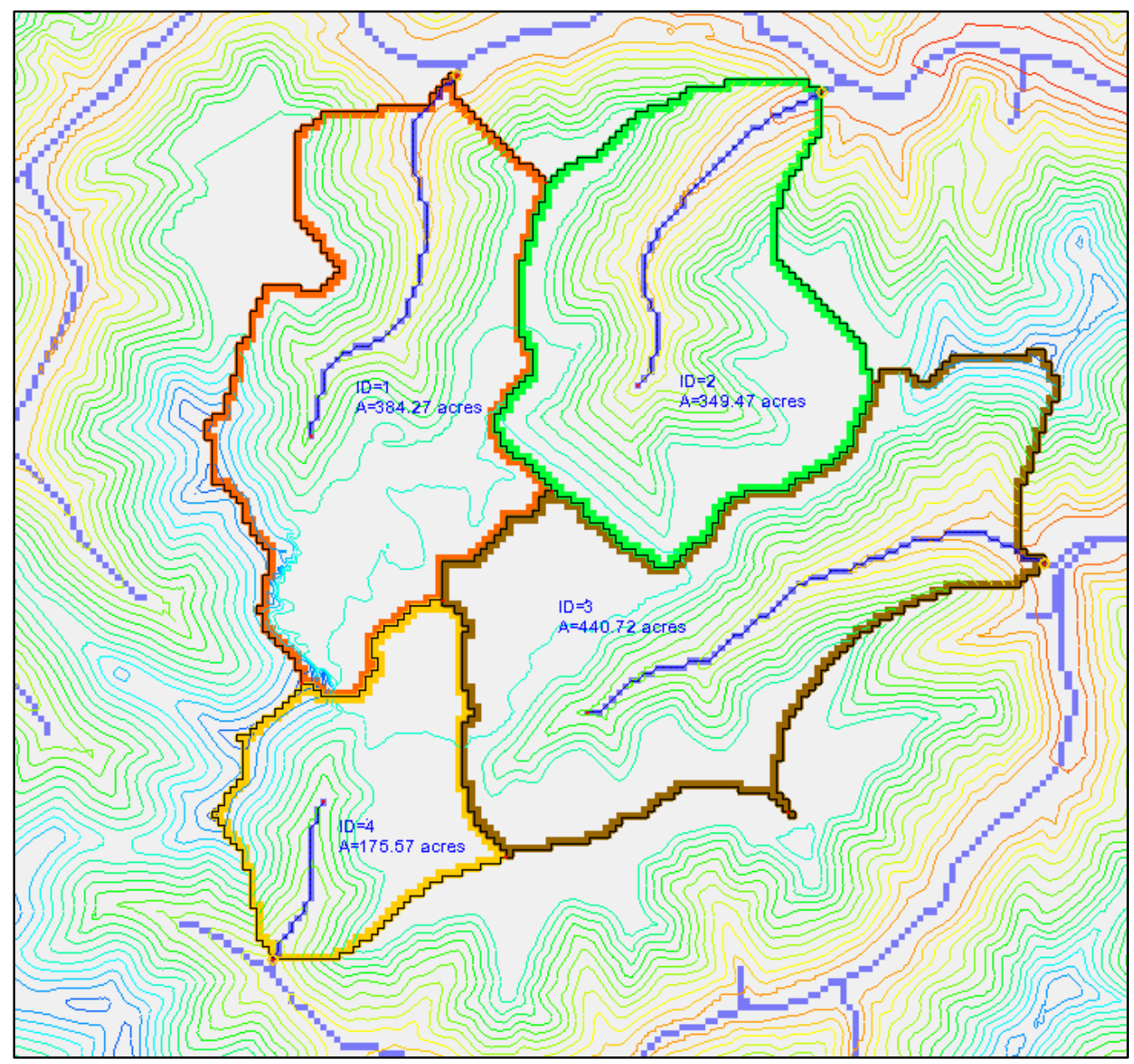

\section{Detention Pond Design}

Figure 2: Retrofit reclamation design

The third reclamation design includes detention basins within the geomorphic landforms to reduce peak discharge and total runoff volumes. The detention ponds were designed so that they could provide yearlong streamflow to the constructed streams as opposed to the intermittent flow generated directly after storm events. This design was intended to increase the perennial 
stream length, increase ephemeral stream length, and increase wetland area through wetland creation within the detention ponds (Figure 3).

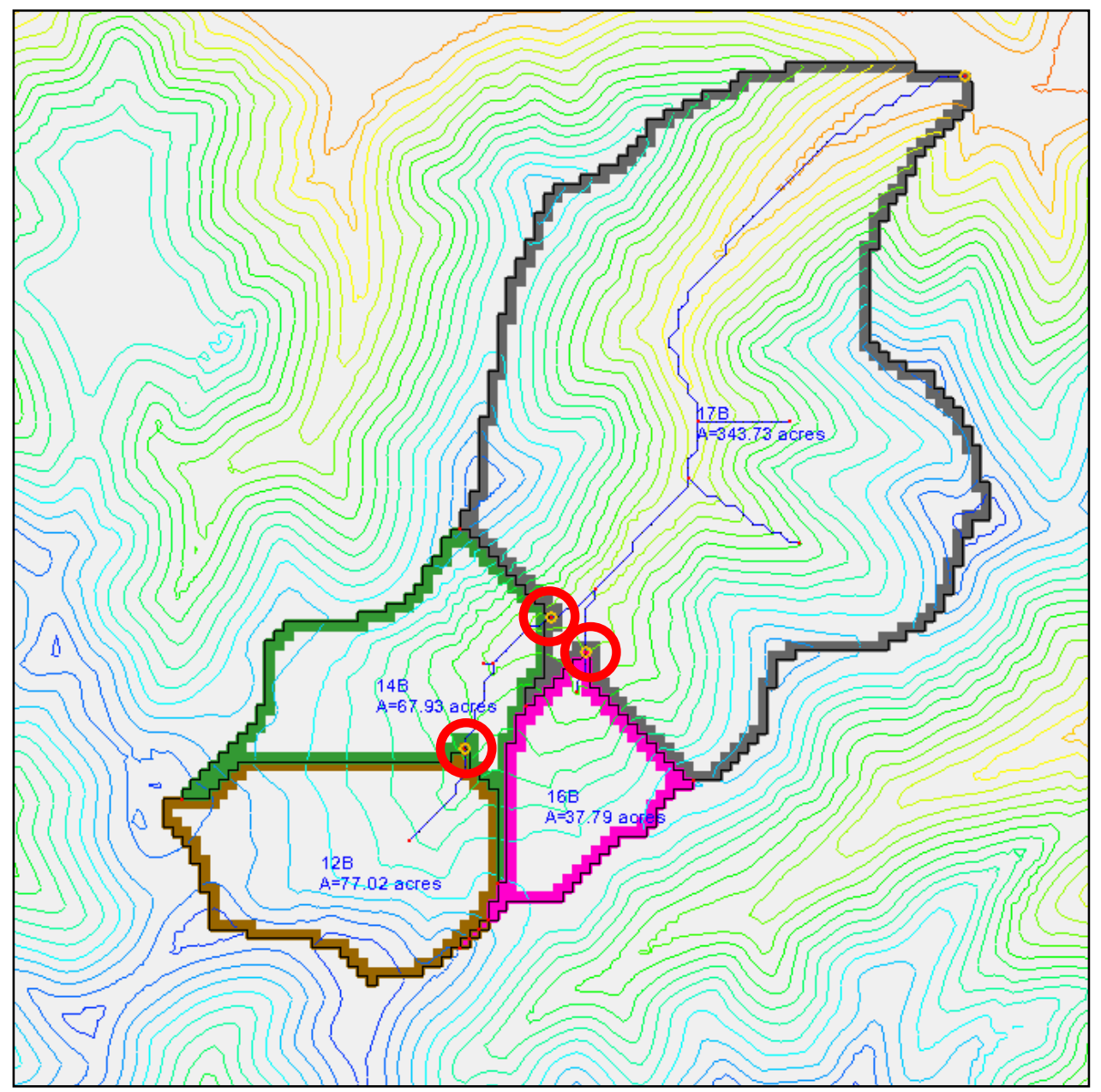

Figure 3: Detention basin reclamation design with detention basins highlighted in red 


\section{Methods}

First, curve numbers were evaluated for southern West Virginia. Then, the hydrologic response of three mountaintop removal mine (MTM) site reclamation designs were modeled and compared to the response of the original watershed using Aquaveo’s Watershed Modeling System (WMS). The hydrologic model of each watershed required delineating the watershed under investigation, assigning curve number values to drainage basins, calculating time of concentration values for each drainage basin, and specifying rainfall distribution types and depths. Both Technical Release 55 (TR-55) and the Computer Program for Project Formulation Hydrology (WinTR-20) were used to perform the hydrologic modeling.

\subsection{Curve Number (CN) Calculation}

Though reclaimed surface mine site curve number $(\mathrm{CN})$ values have been calculated in Pennsylvania (Taylor et al. 2009), Kentucky (Warner et al. 2010; Taylor et al. 2009), Maryland (McCormick and Eshleman 2011), and Ohio (Bonta et al. 1997) curve number values for sites in West Virginia have not yet been calculated. By utilizing United States Geological Survey (USGS) stream data in conjunction with National Oceanic and Atmospheric Administration's (NOAA), precipitation data curve number values were calculated for three watersheds within West Virginia.

The USGS system of stream gaging stations was used to obtain stream hydrograph data from three watersheds in southern West Virginia (WV) (USGS 2013). These data were used to select rainfall events for curve number calculations. Precipitation data used in the curve number calculations were acquired from the National Oceanic and Atmospheric Administration’s (NOAA) National Weather Service (NOAA 2013). The precipitation data provided by the NOAA are generated from radar and rain gauge estimates obtained from the National Weather Service River Forecast Centers and presented in a regularly gridded format where individual points represent calculated rainfall depths. The Department of Environmental Protection (DEP) utilizes these same data in numerous GIS applications relating to mining and natural gas drilling (Shank 2010-11). The three gaging stations used were USGS 03213500 which records the flow out of the Panther Creek watershed located near Panther, WV, USGS 03188900 which records flow out of the Laurel Creek watershed near Fenwick, WV, and USGS 03198350 which records the Clear Fork watershed near Whitesville, WV ( Figure 4). These gaging station sites were 
chosen due to the size of the watersheds being monitored, the range of the available data, and the amount of MTM or development within the watersheds.

To minimize the influence of impervious surfaces such as roads, parking lots, and buildings gaging stations monitoring smaller watersheds $\left(<50 \mathrm{mi}^{2}\right)$ were given preferential consideration over those monitoring larger watersheds. Older gaging stations with longer recording periods (> 5 years) were preferred to maximize the amount of available hydrograph data available for curve number calculations. Recorded data were only included since 2011 for the Laurel Creek watershed, but this site was included due to the small number of usable monitoring stations. USGS stream gaging stations monitoring watersheds associated with towns or cities were rejected due to the impact these developed areas have upon watershed responses to storm events.

\subsubsection{Watersheds Used in CN Calculations}

Panther Creek Watershed

The Panther Creek watershed is $31 \mathrm{mi}^{2}$ in size, has an average basin slope of $0.388 \mathrm{ft} / \mathrm{ft}$, and is an undisturbed forested watershed. Two rainfall events were found that provided a clear storm-response hydrograph where the stream flow was able to return to base flow. These storms occurred on May 5, 2010 and on May 15, 2012.

\section{Laurel Creek Watershed}

The Laurel Creek watershed is $33 \mathrm{mi}^{2}$ in size, has an average basin slope of $0.196 \mathrm{ft} / \mathrm{ft}$, and has approximately 9\% of the total watershed area disturbed by surface mining as of 2011. Only one rainfall event occurring on May 14, 2010 could be found that permitted CN calculations for the Laurel Creek watershed.

\section{Clear Fork Watershed}

The Clear Fork watershed is $63 \mathrm{mi}^{2}$ in size, has an average basin slope of $0.445 \mathrm{ft} / \mathrm{ft}$, and has approximately 7\% of the total watershed area disturbed by surface mining as of 2011. Two rainfall events were found that permitted CN calculations for the Clear Fork Watershed. These storms occurred on May 3, 2010 and July 30, 2010. 


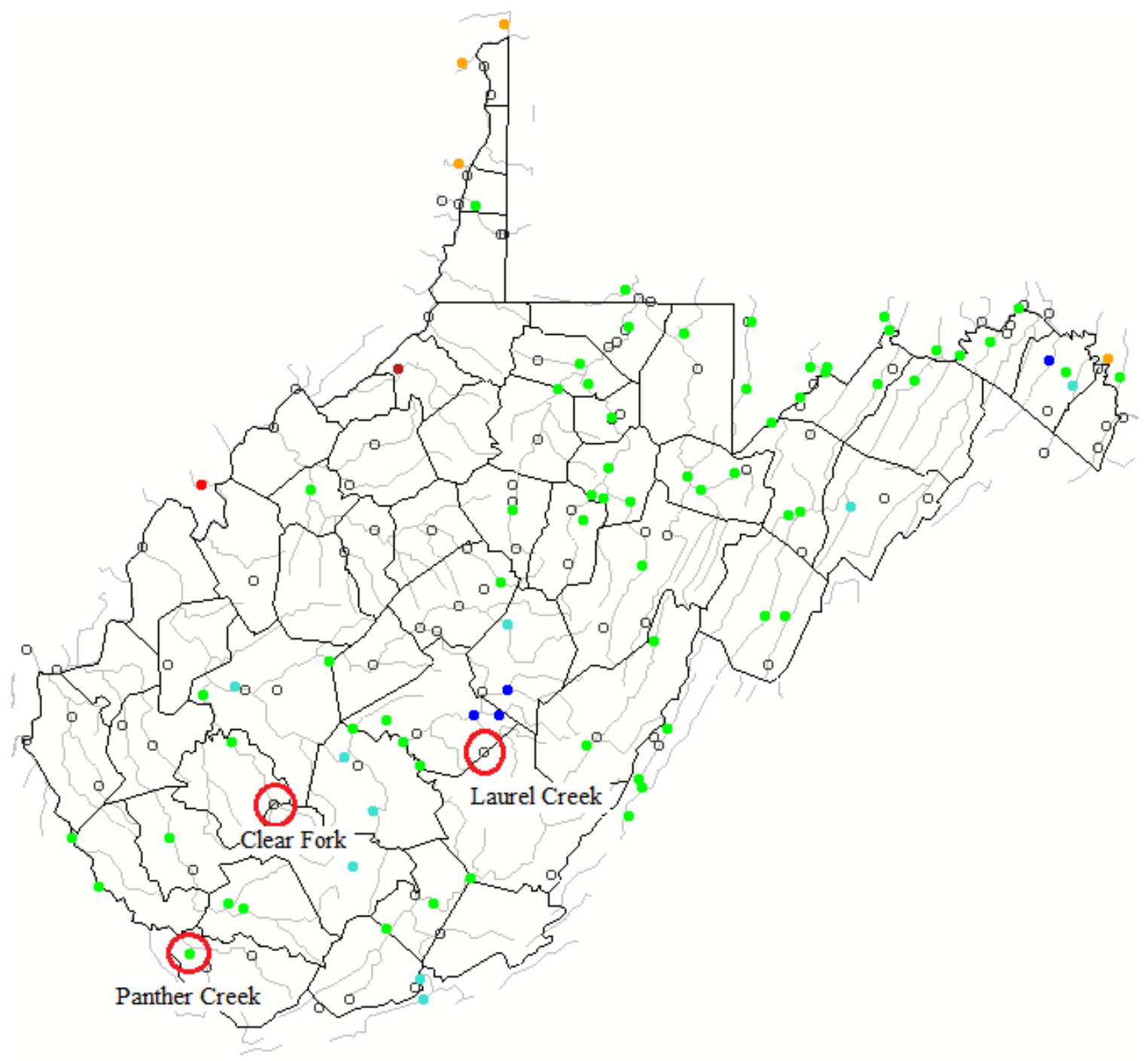

Figure 4: Location of watersheds used in CN calculations: Panther Creek, Clear Fork, and Laurel Creek (USGS 2013)

\subsubsection{Percent Mining Calculations}

The Laurel Creek and Clear Fork watersheds were both affected by surface mining, with both active and reclaimed sites existing within the two watersheds, though the extent to which each watershed was changed by mining was unclear. Satellite images acquired through Aquaveo’s Watershed Management System (WMS) were used to calculate the extent of surface mining in the two watersheds (Figure 5). Polygons were laid over visible mining and reclamation sites and the areas of these polygons were summed together and divided by the total area of the watershed to acquire "percent mined" data for the Laurel Creek and Clear Fork watershed. 


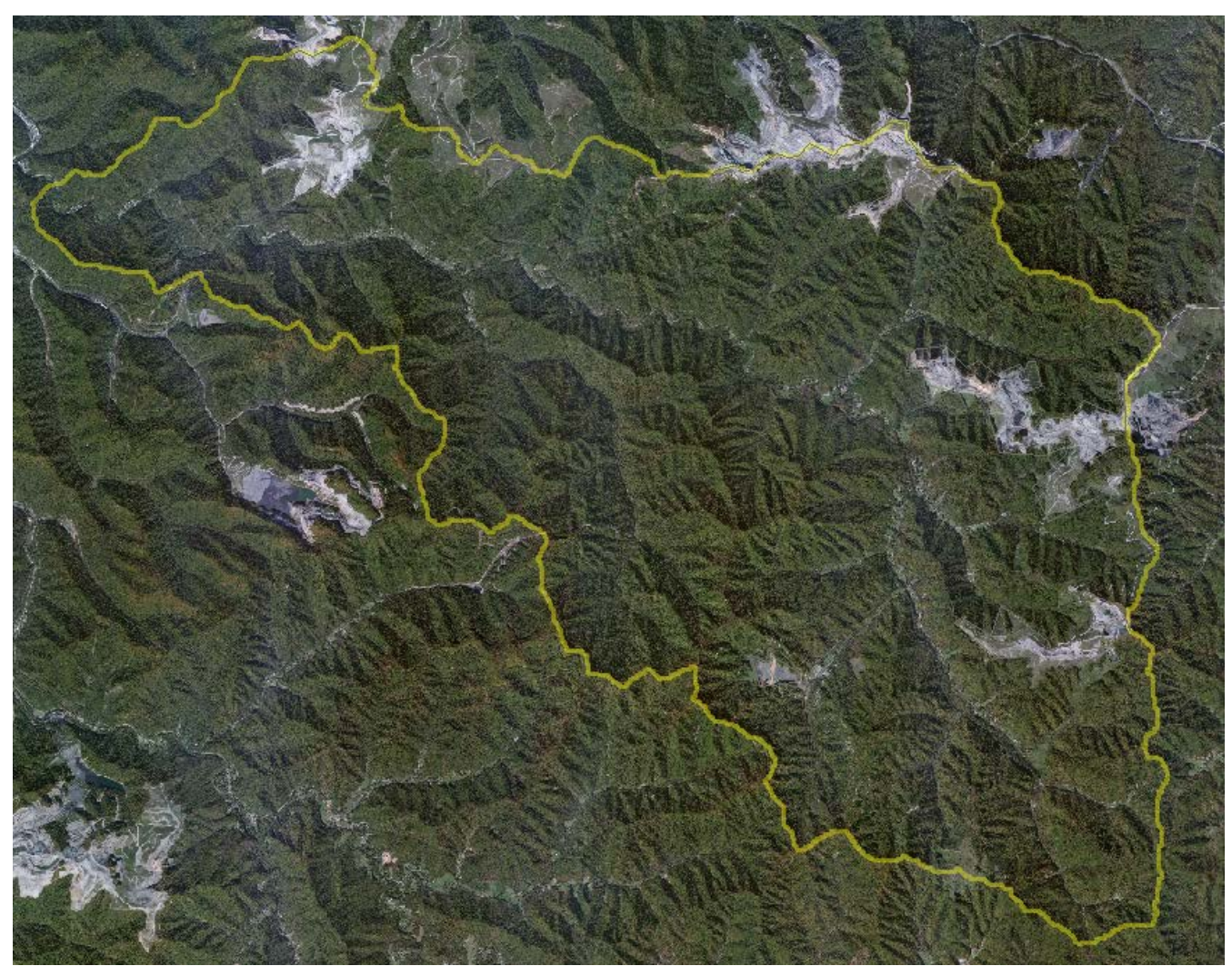

Figure 5: The Clear Fork watershed with satellite imagery used in percent mining calculation

\subsubsection{Data Preparation}

The watersheds were delineated using WMS and the basin shapes were imported into ArcMap 10. With the watershed basin shape in ArcMap 10, the rainfall depth data acquired from the NOAA was placed over top of the basin and trimmed down to cover only the watershed to simplify the rainfall depth calculation (Figure 6). 


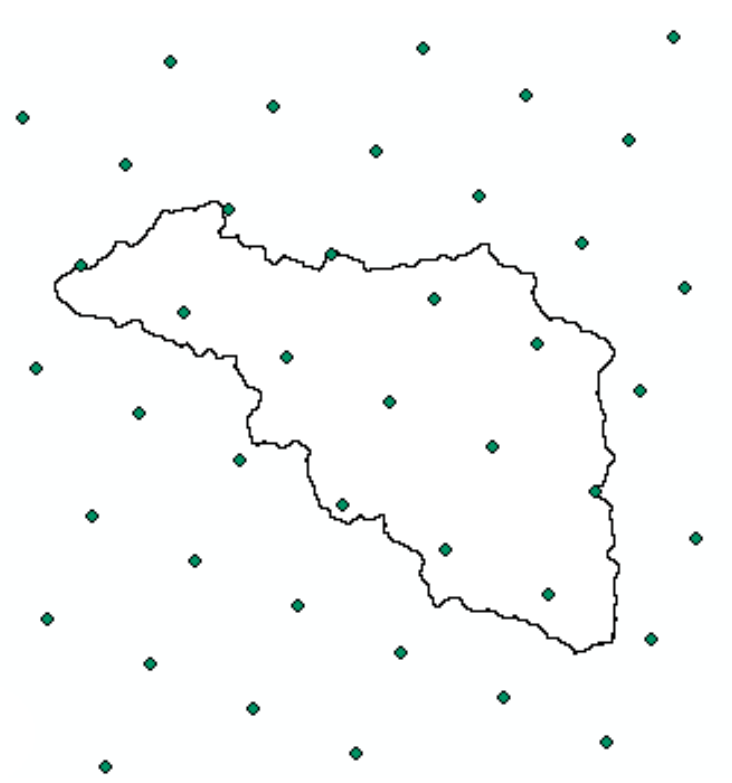

Figure 6: Trimmed NOAA precipitation data layer over top of watershed shape

The Thiessen polygon technique (Bedient et al. 2013) was used to calculate the total precipitation generated over a watershed from a single storm event using the NOAA precipitation data (Figure 7). Due to the regularly gridded nature of the NOAA data the area of effect of each point was square.

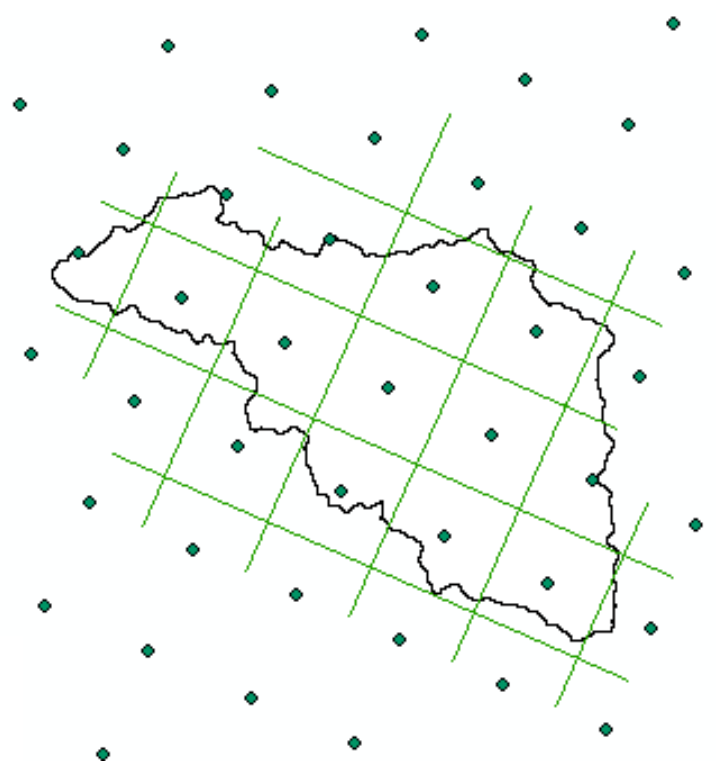

Figure 7: Trimmed NOAA precipitation data layer with the area of effect overlay

The hydrograph data acquired from the USGS stream monitoring system was presented in a tabular format with discharge values at intervals of $15 \mathrm{~min}, 30 \mathrm{~min}$, or $60 \mathrm{~min}$. To calculate the amount of runoff generated between discharge readings each reading was averaged with the 
succeeding recorded value and converted to a volume by multiplying by the time interval between the two values. To calculate the total runoff generated by a given rainfall event, discharge readings that recorded the beginning of the rising limb of the hydrograph until the stream returned to base flow were used. Summing these calculated volumes yielded the total runoff generated from a given rainfall event. This volume was divided by the area of the watershed being studied to provide a runoff depth and allow for $\mathrm{CN}$ calculations.

\subsubsection{Curve Number Calculation}

Using the calculated values for total runoff depth and precipitation depth, a curve number could be calculated for a single rainfall event. Before a $\mathrm{CN}$ can be calculated a value for the storage index of the watershed needed to be calculated. The National Engineering Handbook, NEH-4 Part 630 (SCS 1985) provides the equation below for the calculation of storage:

$$
S=5\left(P+2 Q-\sqrt{4 Q^{2}+5 P Q}\right) \text { for } \lambda=0.20
$$

where, $\mathrm{S}=$ potential maximum retention (in.); $\mathrm{P}=$ rainfall (in.); $\mathrm{Q}=$ runoff (in.) and $\lambda=$ initial abstraction ration (dimensionless).

The storage index can then be used to calculate the $\mathrm{CN}$ of the watershed as follows:

$$
\begin{gathered}
S=\frac{1000}{C N}-10 \\
C N=\frac{1000}{S+10}
\end{gathered}
$$

However, research has indicated that the use of an Initial Abstraction ratio $(\lambda)$ value of 0.05 proved more accurate when performing runoff calculations (Hawkins et al. 2002). Using $\lambda=0.05$ requires altering the storage equation to the one below (Hoomehr et al. 2012):

$$
S=20\left[P+9.5 Q-\left(90.25 P^{2}+20 Q P\right)^{0.5}\right]
$$

After the storage was calculated using this equation the $\mathrm{CN}$ was calculated using equation (3). It is worth noting that the effect of using $\lambda=0.05$ has a greater effect in calculations involving either lower rainfall depths or lower CN values (Hawkins et al. 2002). 


\subsection{Modeling}

Runoff data were generated using 1-, 2-, 5-, 10-, 25-, 50-, 100-, and 500-year, 24 - hour precipitation events. Table 2 below lists the 24 hour rainfall depths for West Virginia as gathered from the NRCS database within TR-55 for a Type II distribution.

Table 2: WV precipitation data

\begin{tabular}{cc}
$\begin{array}{c}\text { Rainfall Return } \\
\text { Period (yr) }\end{array}$ & $\begin{array}{c}\text { 24 - Hr Rainfall } \\
\text { Amount (in) }\end{array}$ \\
\hline 1 & 2.3 \\
2 & 2.66 \\
5 & 3.37 \\
10 & 4 \\
25 & 4.65 \\
50 & 4.97 \\
100 & 5.5 \\
500 & 6.65 \\
\hline
\end{tabular}

\subsubsection{Site Description}

The mine site being studied is located in Logan County, WV within the Island Creek watershed (USGS 2013). Only a portion of the mine site is being studied for alternative reclamation designs. The watershed under investigation flows into Pine Creek from an unnamed tributary (Tributary S) (D.C.C. 2009) through outlet 1C (Figure 8). The watershed is predominately forested with negligible development at the mouth of the watershed ( $<1$ acre). The soil is categorized within the hydrologic soil group (HSG) B (USDA 2013). 


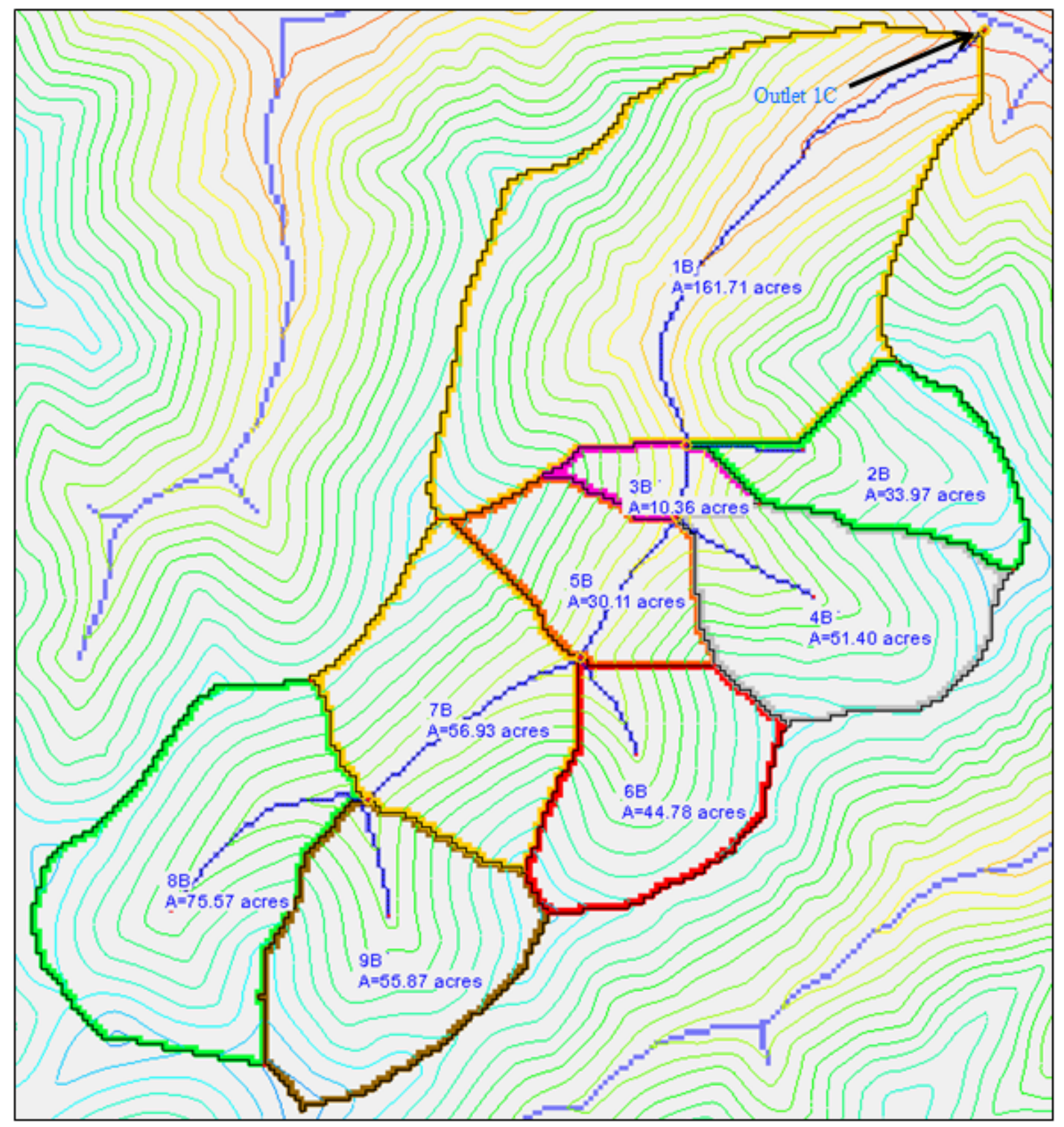

Figure 8: Original, undisturbed watershed

\subsubsection{Hydrologic Modeling}

The following sections describe the hydrologic modeling methods applied to the original topography, the conventional valley fill design, and the three alternative geomorphic landform design alternatives. Percent difference values were calculated using the equation: 


$$
\text { Percent Change }(\%)=\frac{\text { Reclamation Design Value-Original Watershed Value }}{\text { Original Watershed Value }} \times 100
$$

\subsubsection{Undisturbed topography}

The hydrologic model of the original topography was created using Aquaveo’s WMS and the hydrologic response of the watershed was modeled using TR-55. Curve number values were then selected for the watershed.

Curve number $(\mathrm{CN})$ values are used in hydrologic modeling to estimate the conversion of rainfall to surface water runoff. Watersheds with higher CN values will generate more runoff than watersheds with lower $\mathrm{CN}$ values (e.g., compacted soil at a construction site would have a higher CN than a freshly tilled field). The NRCS Technical Release 55 Urban Hydrology for Small Watersheds (USDA 1986) provides a CN value of 66 for soil of HSG B in "poor" condition that represents a "worst-case" scenario where a given storm-event is most likely to produce the largest amount of surface runoff in a forested watershed. A surface water runoff analysis of the mine site prepared by the Decota Consulting Company also used a CN value of 66, and their results were used to compare the runoff volume and peak discharge data generated by the models generated in WMS.

Hawkins et al. (1993) studied the accuracy of soil-defined CNs and found that soildefined CNs for forested watersheds did not accurately represent CN values calculated from rainfall and runoff data. Tedela et al. (2012) calculated CNs for two forested watersheds within West Virginia using 53 years of rainfall and runoff data and found that a CN value of 84 most accurately described the hydrologic response of the watershed.

Results of the hydrologic modeling of the alternative reclamation designs were compared against the data generated for the original watershed at both a $\mathrm{CN}$ of 66 and a $\mathrm{CN}$ of 84 . Because the $\mathrm{CN}$ value of 84 was calculated using only two undisturbed watersheds in central West Virginia more emphasis was placed upon the comparisons between the hydrologic response of the undisturbed topography at a CN of 66 and the alternative reclamation designs. 
The time of concentration for each sub-basin within the original, undisturbed watershed was calculated using the Kirpich Method for overland flow on grassy earth (Mountains):

$$
T_{c}=m \times 0.00013 \times\left(\frac{L^{0.77}}{S^{0.385}}\right) \times C_{t}
$$

Where, $\mathrm{m}$ = Earth type coefficient (2.000 for grassy earth equation), $\mathrm{L}=$ Length of overland flow $(\mathrm{ft}), \mathrm{S}=$ average overland slope $(\mathrm{ft} / \mathrm{ft})$ and $\mathrm{C}_{\mathrm{t}}=$ time of concentration coefficient

The Kirpich Method determines the time of concentration using a concentration coefficient calculated from the following equation:

$$
C_{t}=1.0+((80-C N) \times 0.04)
$$

\subsubsection{Approximate Original Contour}

The conventional reclamation of the study site being investigated is a variation of the AOC reclamation design. Instead of returning the mountain to its approximate contour the design consists of a flat mountain top with a valley fill at the headwaters of the watershed. The reclamation design will be referred to as the AOC design throughout this study. Sedimentation ditches are used to redirect flow to National Pollutant Discharge Elimination System (NPDES) permit points. The valley fill is outfitted with groin ditches on either side of the fill meant to redirect flow away from the valley fill face and $20 \mathrm{ft}$ horizontal benches every 50 vertical feet to slow runoff that did flow down the face. Sediment ditches are located along the edges of the mined areas to direct runoff to designated NPDES permit points which then drained into established drainage basins. The AOC watershed was delineated using WMS and the hydrologic response was calculated using WinTR-20. The presence of sediment control structures within the design required the use of WinTR-20 over TR-55 which does not have the ability to model such control structures. The hydrologic response of the AOC watershed was calculated and compared to the SEDCAD model results found in the permit file as a validation of the accuracy of the hydrologic modeling of the alternative reclamation designs. The selected $\mathrm{CN}$ values for individual drainage basins were based off of the CNs used in the permit. CNs ranged from 82 for mined land to 66 for undisturbed forested land in poor hydrologic condition. The time of concentration for each sub-basin within the AOC watershed was calculated using the Kirpich Method for overland flow on grassy earth (Mountains) (Equation 12). The Kirpich Method for 
overland flow on bare earth (Mountains) was also used to calculate time of concentration values for sub-basins that would be disturbed by the mining. This calculation uses the same equation as for overland flow on grass earth, but has an earth type coefficient of 1.000 instead of 2.000 .

\subsubsection{Geomorphic Landform Design}

The geomorphic landform design (GLD) has no drainage ditches or detention ponds; instead it consists of man-made sub-basins that direct flow to constructed channels. The GLD was delineated with WMS and TR-55 was used in the hydrologic modeling of the watershed. TR-55 was used for the GLD watershed due to the lack of ditches or detention ponds that made WinTR-20 necessary for the AOC design. The GLD watershed was modeled using the CN values of 84 and 67 . There is currently no official range of CNs that can be applied to watersheds that have been impacted by mountaintop removal mining (MTM) reclamation, but a number of authors have researched the issue and published CNs found in a number of MTM sites (Taylor et al. 2009 (60-90); Warner et al. 2010 (62-94); Bonta et al. 1997 (87-97); Ritter and Garnder, 1991 (72-89)). The CN of 84 was selected by averaging the average CN values found by all of the authors and the $\mathrm{CN}$ of 67 was selected so that the results of the modeling could be compared to those found within the mine site permit file for the reclaimed watershed 5 years after reclamation had been completed. This CN is provided by the NRCS and is used to describe a Brush/Weed/Grass mixture of HSG B in poor hydrologic condition. This CN was also used to represent the long-term hydrologic response of the watershed after reclamation has been completed (Table 3). 
Table 3: CN values used to model hydrologic response of alternative reclamation designs under different conditions

\begin{tabular}{ccc}
\hline Alternative Reclamation Design & CN Value & Representative Condition \\
\hline GLD & 84 & During-mining \\
Detention Pond & & \\
Retrofit & 67 & Post-mining, short-term ( $<5$ years $)$ \\
GLD & & \\
Detention Pond & & \\
Retrofit & 60 & Post-mining, long-term ( $>5$ years $)$ \\
Detention Pond & & \\
\hline Retrofit & & \\
\hline
\end{tabular}

Note: GLD design long-term reclamation was modeled at $\mathrm{CN}=67$

The time of concentration for each sub-basin within the GLD watershed was calculated using the Kirpich Method for overland flow on grassy earth (Mountains) (Equation 12). The Kirpich Method for overland flow on bare earth (Mountains) was also used to calculate time of concentration values for sub-basins that would be disturbed by mining.

\subsubsection{Detention Pond Design}

The second reclamation design utilizes GLD principles, but includes three detention ponds within the watershed in an effort to reduce peak flows. The watershed was delineated with WMS and the hydrologic response was calculated with TR-20 due to inclusion of detention ponds in the design. Curve number values of 84,67 , and 60 were used to model the hydrologic response of the watershed (Table 3). The curve number value of 84 was used to describe the hydrologic response of the watershed during mining. The $\mathrm{CN}$ value of 67 was used to represent short-term ( $<5$ years) post-mining conditions. The $\mathrm{CN}$ value of 60 was used to describe the long-term ( $>5$ years) post-mining hydrologic response of the watershed. The inclusion of detention basins in the reclamation design required the use of WinTR-20 in place of TR-55. Runoff data was generated using 1-year, 2-year, 5-year, 10-year, 25-year, 50-year, 100-year, and 500-year 24 - hour precipitation depths with Type II rainfall distribution. 
The time of concentration for each sub-basin within the detention pond watershed was calculated using the Kirpich Method for overland flow on grassy earth (Mountains) (Equation 12). The Kirpich Method for overland flow on bare earth (Mountains) was also used to calculate time of concentration values for sub-basins that would be disturbed by mining.

\subsubsection{Retrofit Design}

The third reclamation design is a retrofit of the AOC reclamation design. The design utilizes GLD principles, but unlike the previous designs is not a stand-alone reclamation design; instead it requires placing of loose spoil on top of the AOC reclamation design to create four GLD watersheds that direct flow into four separate tributaries. TR-55 was used to model the retrofit design because of the lack of detention basins that made the use of WinTR-20 necessary. $\mathrm{CN}$ values of 60,67 , and 84 were used (Table 3). When examining the hydrologic responses of reclaimed surface mines in eastern Kentucky, Taylor et al. (2009) found that mine sites reclaimed using loose-dumped sandstone spoil in accordance with the Forestry Reclamation Approach (FRA) had a mean CN of 67 when calculated using $\lambda=0.05$ (Taylor et al. 2009). This $\mathrm{CN}$ was used to model the short term ( $<5$ years) hydrologic response of the reclaimed mine site. Another study looking at steep-sloped surface mine sites in east Tennessee reclaimed using lowcompaction principles in accordance with the FRA by Hoomehr et al. (2012) found CN values between 58.5 and 60 (Hoomehr et al. 2012). This CN was used to model the long term (> 5 years) hydrologic response of the retrofit design. Runoff data was generated using 1-year, 2year, 5-year, 10-year, 25-year, 50-year, 100- year, and 500-year 24 hour precipitation depths with Type II rainfall distribution.

The time of concentration for each sub-basin within the AOC watershed was calculated using the Kirpich Method for overland flow on grassy earth (Mountains) (Equation 12). The Kirpich Method for overland flow on bare earth (Mountains) was also used to calculate time of concentration values for sub-basins that would be disturbed by mining. 


\section{Results and Discussion}

\subsection{Curve Number Results}

The results of the curve number (CN) calculations are displayed in Table 4. The CNs calculated for the Panther Creek watershed were greater than CN values stated by the NRCS for forested watersheds of the same soil type with calculated values of 85 and 91. However, these values are within the range of CNs calculated for other forested watersheds in West Virginia (62.5 - 99.2, Tedela et al. 2012). The CN calculated for the Laurel Creek watershed was within values found for watersheds that had been impacted by MTM with a calculated CN of 91 (68 92, McCormick and Eshleman 2011). The Clear Fork watershed had a calculated CN of 76 and 77 and was within values found for watersheds that had been affected by MTM (72 - 89: Ritter and Gardner 1991).

Table 4: Calculated CN values for three watersheds in southern WV

\begin{tabular}{|c|c|c|c|c|}
\hline Watershed & $\begin{array}{l}\text { Watershed } \\
\text { Area }\left(\mathrm{mi}^{2}\right)\end{array}$ & $\begin{array}{l}\text { Amount of } \\
\text { Mining (\%) }\end{array}$ & $\begin{array}{c}\text { Storm Event } \\
\text { Date }\end{array}$ & $\mathrm{CN}(\lambda=\mathbf{0 . 0 5})$ \\
\hline \multirow[b]{2}{*}{ Panther Creek } & \multirow[b]{2}{*}{31} & \multirow[b]{2}{*}{0} & May 2, 2010 & 91 \\
\hline & & & $\begin{array}{c}\text { May 15, } \\
2012\end{array}$ & 85 \\
\hline \multirow{2}{*}{ Clear Fork } & \multirow{2}{*}{63} & \multirow{2}{*}{7} & May 3, 2010 & 76 \\
\hline & & & July 30, 2010 & 77 \\
\hline Laurel Creek & 33 & 9 & $\begin{array}{c}\text { May 14, } \\
2010\end{array}$ & 91 \\
\hline
\end{tabular}

\subsection{Hydrologic Modeling}

The results of the hydrologic modeling of the reclamation designs are presented in the following sections. The delineated basin is presented followed by the basin data for each subbasin. The hydrologic response of the watershed is displayed and for the GLD, retrofit, and detention pond designs. The hydrologic responses are then compared with the original topography and conventional valley fill results. 


\subsubsection{Original Topography}

The results for the original pre-mining watershed are displayed in Tables $5-7$. The watershed is composed of nine sub-basins ranging in size from 162 acres to 10.4 acres with an average size of 57.9 acres (Figure 9).

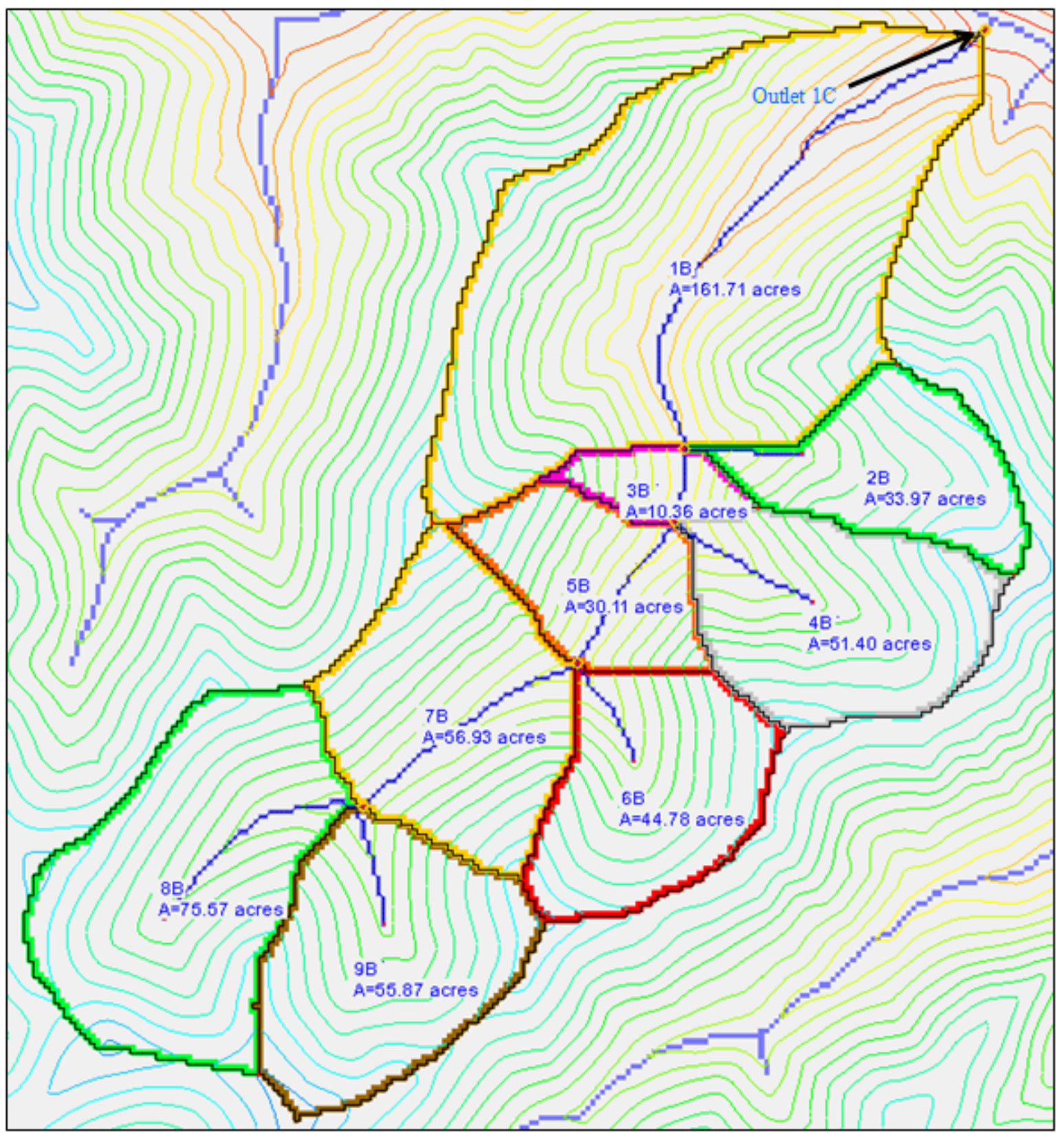

Figure 9: Original topography delineated watershed and watershed sub-basins

Table 5 displays the area, basin slope, average overland flow (AOFD), basin length, maximum flow distance (MFD), maximum flow slope (MFS), maximum stream length (MSL), and maximum stream slope (MSS) of the nine sub-basins within the original topography 
watershed. These data will be compared to basin data gathered from the AOC variance topography and the geomorphic landform designs.

Table 5: Original topography basin data

\begin{tabular}{|c|c|c|c|c|c|c|c|c|c|}
\hline & 1B & 2B & 3B & $4 B$ & 5B & 6B & 7B & 8B & 9B \\
\hline Area (ac) & 162.0 & 34.0 & 10.4 & 51.4 & 30.1 & 44.8 & 56.9 & 75.6 & 55.9 \\
\hline \multicolumn{10}{|l|}{ Basin } \\
\hline $\begin{array}{l}\text { Slope } \\
(\mathbf{f t} / \mathbf{f t})\end{array}$ & 0.56 & 0.44 & 0.56 & 0.49 & 0.56 & 0.50 & 0.53 & 0.47 & 0.48 \\
\hline $\begin{array}{c}\text { AOFD } \\
\text { (ft) }\end{array}$ & 624 & 820 & 296 & 595 & 409 & 592 & 462 & 509 & 629 \\
\hline$L$ (ft) & 4793 & 2317 & 949 & 2218 & 1459 & 1672 & 1761 & 2387 & 2071 \\
\hline $\operatorname{MFD}(\mathbf{f t})$ & 5321 & 2601 & 1127 & 2587 & 2316 & 2044 & 2374 & 2907 & 2341 \\
\hline $\begin{array}{l}\text { MFS } \\
(\mathbf{f t} / \mathbf{f t})\end{array}$ & 0.16 & 0.32 & 0.47 & 0.32 & 0.31 & 0.34 & 0.28 & 0.22 & 0.29 \\
\hline MSL (ft) & 3888 & 776 & 459 & 1115 & 1157 & 782 & 1731 & 1662 & 846 \\
\hline $\begin{array}{l}\text { MSS } \\
(\mathbf{f t} / \mathbf{f t})\end{array}$ & 0.06 & 0.35 & 0.03 & 0.24 & 0.06 & 0.18 & 0.07 & 0.11 & 0.11 \\
\hline
\end{tabular}

Note: AOFD is average overland flow, $\mathrm{L}$ is basin length, MFD is maximum flow distance, MFS is maximum flow slope, MSL is maximum stream length and MSS is maximum stream slope.

The maximum peak discharge and maximum discharge volume were seen at the 500-year return period storm event at 3,209 $\mathrm{ft}^{3} / \mathrm{sec}$ and $8.98 \times 10^{6} \mathrm{ft}^{3}$ respectively (Table 6).

At a $\mathrm{CN}$ equal to 66 the peak discharge and discharge volume experienced at the watershed outlet decreased by an average of $74 \%$ and $55 \%$ respectively when compared to the discharges at a CN equal to 84 (Table 7). The maximum decrease occurred at the 1-year storm event which saw a decrease in peak discharge of $91 \%$ from 588 cfs to 54.0 cfs (Table 7). The 
discharge volume fell by $74 \%$ from $1.82 \times 10^{6} \mathrm{ft}^{3}$ to $4.69 \times 10^{5} \mathrm{ft}^{3}$ (Table 7). The time of peak was increased by $2 \%$ from 726 minutes to 738 minutes (Table 7).

Table 6: Hydrograph data for outlet $1 \mathrm{C}$ of original topography $(\mathrm{CN}=84)$

\begin{tabular}{|c|c|c|c|}
\hline $\begin{array}{c}\text { Rainfall } \\
\text { Return Period } \\
\text { (yr) }\end{array}$ & $\begin{array}{c}\text { Peak Discharge } \\
\text { (cfs) }\end{array}$ & $\begin{array}{c}\text { Time of Peak } \\
\text { (min) }\end{array}$ & $\begin{array}{c}\text { Discharge } \\
\text { Volume }\left(\mathbf{f t}^{3}\right)\end{array}$ \\
\hline 1 & 588 & 726 & $1.82 \times 10^{6}$ \\
\hline 2 & 772 & 726 & $2.34 \times 10^{6}$ \\
\hline 5 & 1,165 & 726 & $3.43 \times 10^{6}$ \\
\hline 10 & 1,535 & 726 & $4.45 \times 10^{6}$ \\
\hline 25 & 1,932 & 726 & $5.53 \times 10^{6}$ \\
\hline 50 & 2,131 & 726 & $6.07 \times 10^{6}$ \\
\hline 100 & 2,466 & 726 & $6.98 \times 10^{6}$ \\
\hline 500 & 3,209 & 726 & $8.98 \times 10^{6}$ \\
\hline
\end{tabular}

The storm response hydrograph (Figure 10) illustrates the watershed response for a 2year storm at $\mathrm{CN}$ values of 84 and 66. (Additional calculated hydrographs are available in Appendix A). With the Type II rainfall distribution selected within TR-55 for every test the hydrographs would be expected to have the same shape. Both hydrographs have the same shape and follow the same pattern; no runoff for a long duration followed by a sudden increase in runoff which is in turn followed by a sudden decrease in runoff that ends with a long duration of comparatively low volume runoff. 
Table 7: Hydrograph data for outlet $1 \mathrm{C}$ of original topography $(\mathrm{CN}=66)$

\begin{tabular}{|c|c|c|c|}
\hline $\begin{array}{c}\text { Rainfall } \\
\text { Return Period } \\
\text { (yr) }\end{array}$ & $\begin{array}{c}\text { Peak Discharge } \\
\text { (cfs) }\end{array}$ & $\begin{array}{c}\text { Time of Peak } \\
\text { (min) }\end{array}$ & $\begin{array}{r}\text { Discharge } \\
\text { Volume }\left(\mathrm{ft}^{\mathbf{3}}\right)\end{array}$ \\
\hline 1 & 54 & 738 & $4.69 \times 10^{5}$ \\
\hline 2 & 104 & 738 & $7.34 \times 10^{5}$ \\
\hline 5 & 246 & 738 & $1.38 \times 10^{6}$ \\
\hline 10 & 398 & 738 & $2.04 \times 10^{6}$ \\
\hline 25 & 580 & 738 & $2.79 \times 10^{6}$ \\
\hline 50 & 678 & 738 & $3.19 \times 10^{6}$ \\
\hline 100 & 849 & 738 & $3.87 \times 10^{6}$ \\
\hline 500 & 1,256 & 738 & $5.45 \times 10^{6}$ \\
\hline
\end{tabular}




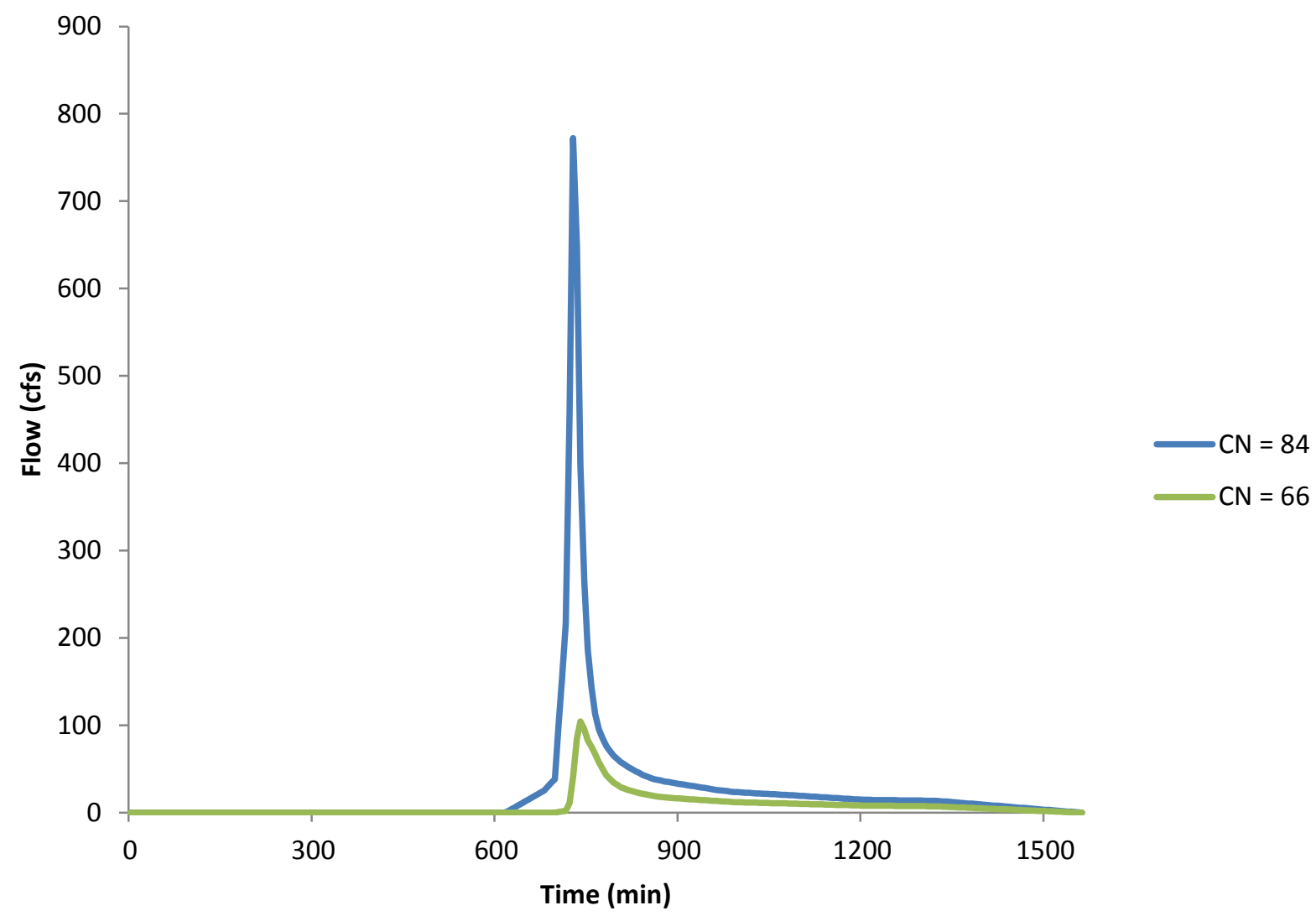

Figure 10: Storm response hydrograph for a 2-year storm at outlet $1 \mathrm{C}$ of original topography for varying $\mathrm{CN}$

\subsubsection{Approximate Original Contour Variance}

The approximate original contour (AOC) variance reclamation design found in permit S5008-09 was imported into WMS. The hydrologic response of the delineated watershed was calculated and compared to the response calculated in permit S-5008-09 (DCC 2009) to check the accuracy of the hydrograph data acquired from WMS. The hydrologic response of the AOC watershed was modeled in the permit using Sediment, Erosion, Discharge by Computer Aided Design (SEDCAD) for a 25-year storm event. The calculated peak discharge $\left(\mathrm{Q}_{\mathrm{p}}\right)$ of the watershed was $622.14 \mathrm{ft}^{3} / \mathrm{sec}$. The hydrologic response of the AOC watershed for a 25-year rainfall event calculated in this study calculated a $Q_{p}$ value of $788.1 \mathrm{ft}^{3} / \mathrm{sec}, 27 \%$ higher than the value found in the permit (Table 8). Time of peak and total discharge volume data were not provided within the permit. 
Table 8: Hydrograph data for outlet 1C of AOC variance

\begin{tabular}{ccc}
\hline $\begin{array}{c}\text { Rainfall Return } \\
\text { Period (yr) }\end{array}$ & $\begin{array}{r}\text { Peak Discharge } \\
\left(\mathbf{f t}^{\mathbf{3}} / \mathbf{s e c}\right)\end{array}$ & Time of Peak (min) \\
\hline 1 & 15.6 & 758 \\
2 & 28.9 & 755 \\
5 & 114 & 733 \\
10 & 428 & 727 \\
25 & 788 & 726 \\
50 & 940 & 724 \\
100 & 1,168 & 722 \\
\hline 500 & 1,628 & \\
\hline
\end{tabular}

The difference in $\mathrm{Q}_{\mathrm{p}}$ values could be due to a number of factors. The post-mining map used in the SEDCAD modeling has a smaller valley fill, two detention basins located at the top of the valley fill not found in the AutoCAD file, and different locations for the two detention basins at the base of the valley fill (Figure 11). The resized valley fill and relocated detention basins can be found in the AutoCAD post-mining map used in the WMS modeling (Figure 12). The larger valley fill, relocated detention basins at the bottom of the valley fill and removal of the detention basins at the top of the valley fill could contribute to higher peak discharge values and explain the $27 \%$ difference between the previously reported results and the results found in this study. 


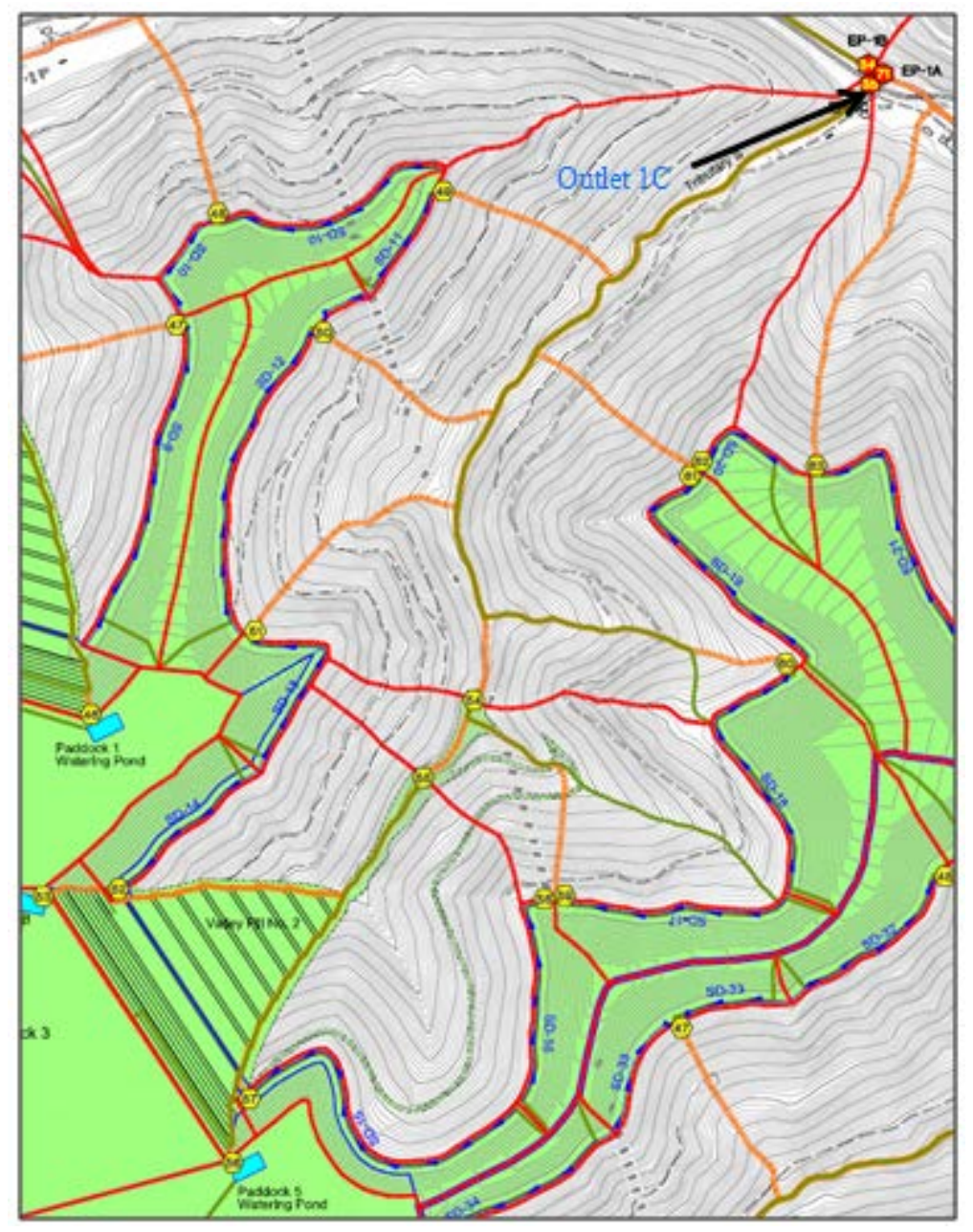

Figure 11: Post-mining map used in SEDCAD modeling (clipped to highlight watershed being modeled) (DCC 2009)

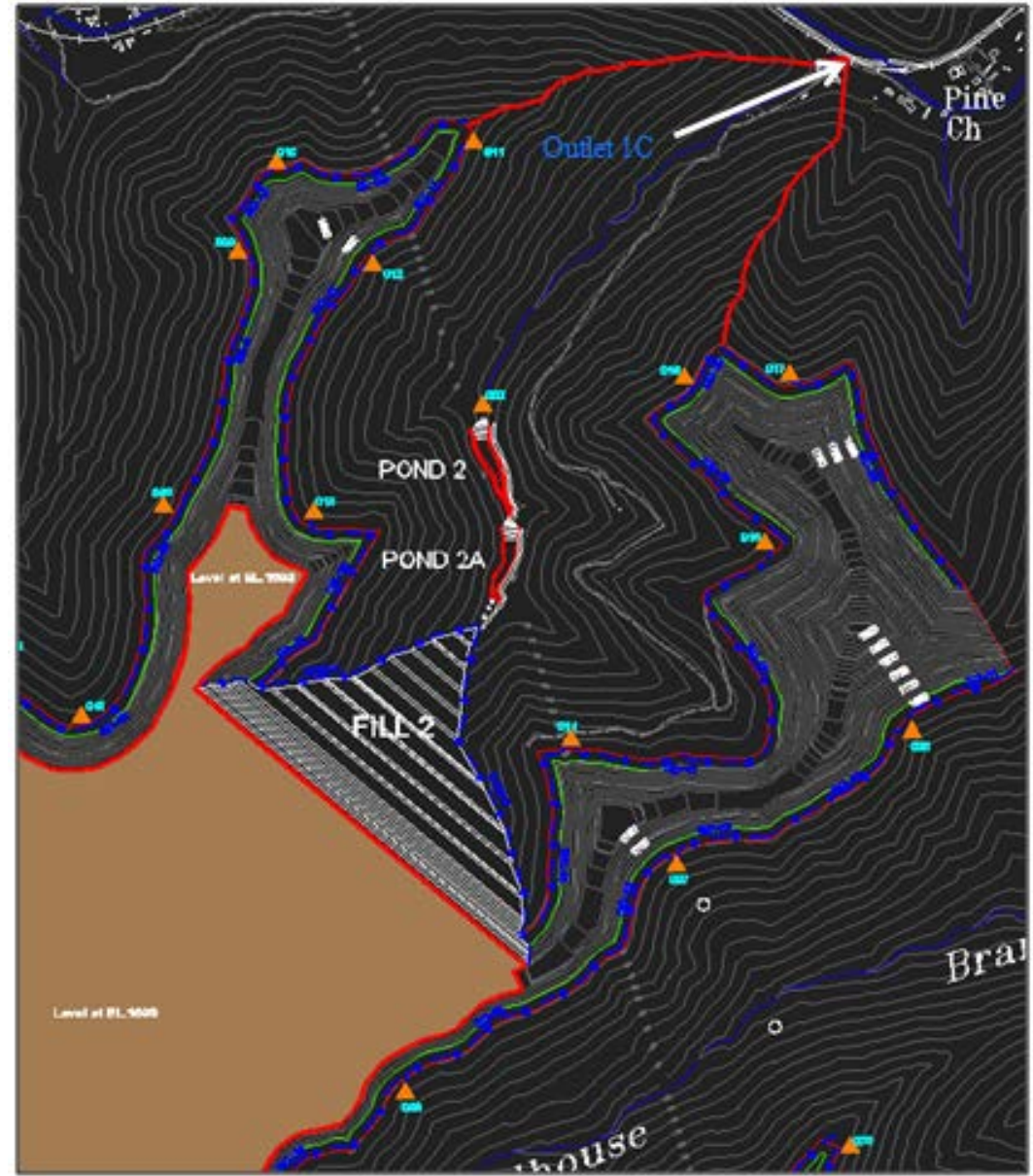

Figure 12: Revised post-mining map used in WMS modeling (clipped to highlight watershed being modeled) Note: Red line added near watershed outlet for illustrative purposes. 
WMS was used to delineate the AOC watershed, compute basin data, and compute time of concentration data for each basin (Table 9). These data were used to evaluate the hydrologic response of the watershed. Curve number data for each basin were acquired from the original permit file for the mine site (DCC 2009). The AOC watershed consists of fifteen drainage basins ranging in size from 126 acres to 1.71 acres with an average basin size of 30.1 acres, $48 \%$ smaller than the average basin size of the original topography (57.9 acres) (Table 9). The smaller drainage basins on the perimeter of the watershed are formed as a result of drainage and storage ditches that redirect runoff through National Pollutant Discharge Elimination System (NPDES) permit points. The average basin slope of the AOC watershed was reduced by $35 \%$ from $0.51 \mathrm{ft} / \mathrm{ft}$ in the original topography to $0.33 \mathrm{ft} / \mathrm{ft}$ (Table 9). The average basin AOFD was reduced by $77 \%$ from $548 \mathrm{ft}$ in the original topography to $124 \mathrm{ft}$ in the AOC watershed (Table 9). The average basin length and MFD were both reduced by $76 \%$ to $526 \mathrm{ft}$ and $635 \mathrm{ft}$, respectively (Table 9). The MFS was reduced by $56 \%$ from $0.30 \mathrm{ft} / \mathrm{ft}$ to $0.13 \mathrm{ft} / \mathrm{ft}$ (Table 9). The MSL was reduced by $72 \%$ from 1,380 ft to $381 \mathrm{ft}$ (Table 9). The MSS for the AOC watershed was 44\% lower than the original topography at $0.07 \mathrm{ft} / \mathrm{ft}$ (Table 9). 


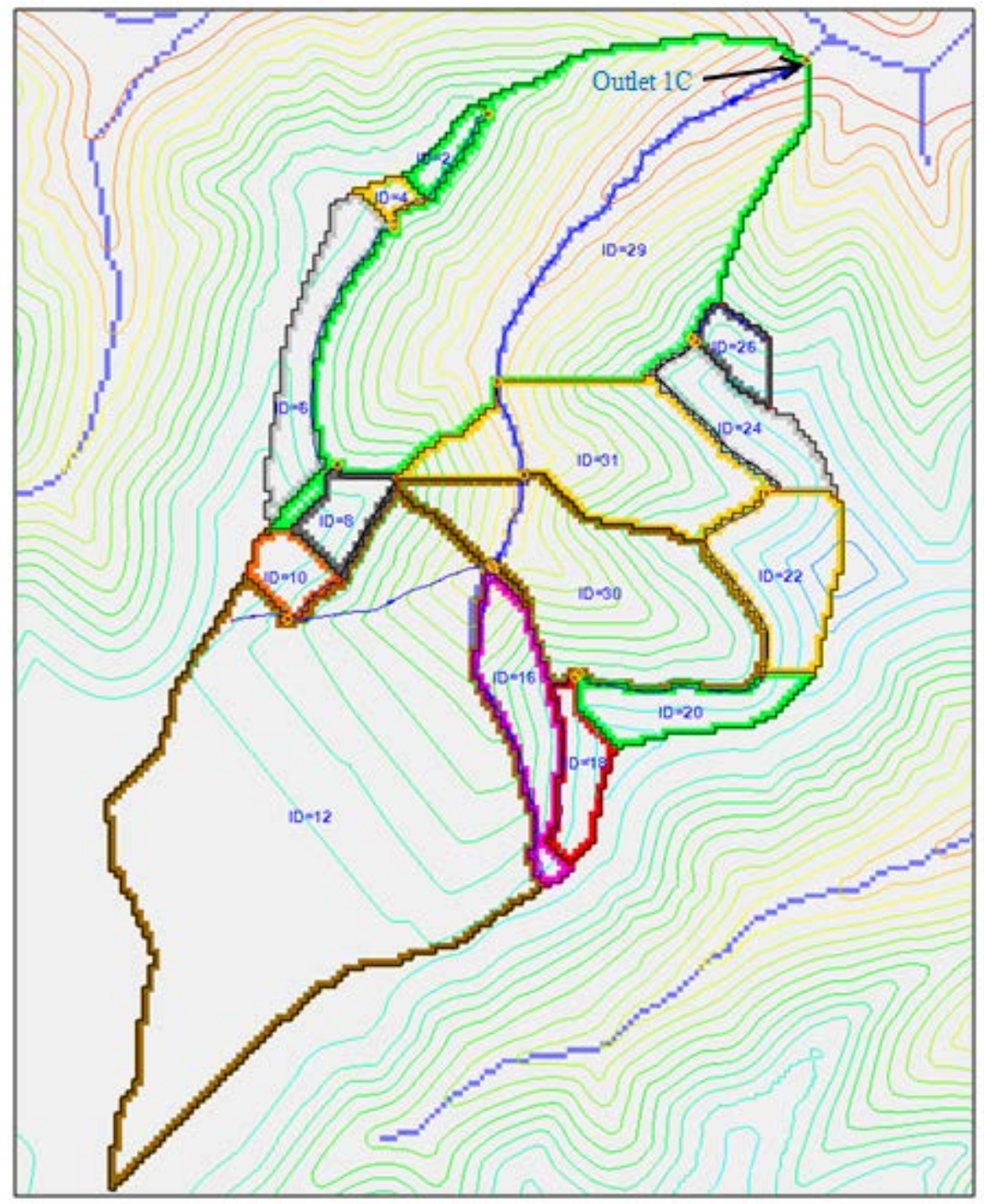

Figure 13: Delineated AOC watershed 
Table 9: AOC basin data

\begin{tabular}{|c|c|c|c|c|c|c|c|c|c|c|c|c|c|c|c|}
\hline & 31B & 30B & 29B & 26B & 24B & 22B & 20B & 18B & $16 B$ & 12B & 10B & 8B & $6 B$ & 4B & 2B \\
\hline Area (ac) & 33.4 & 42.4 & 126 & 4.61 & 10.9 & 16.8 & 10.0 & 7.0 & 13.2 & 159 & 5.1 & 5.9 & 13.4 & 1.7 & 2.8 \\
\hline Basin Slope (ft/ft) & 0.54 & 0.53 & 0.55 & 0.31 & 0.35 & 0.38 & 0.29 & 0.30 & 0.52 & 0.16 & 0.18 & 0.23 & 0.24 & 0.26 & 0.16 \\
\hline AOFD (ft) & 221 & 284 & 165 & 48.4 & 47.0 & 75.6 & 41.9 & 35.8 & 48.6 & 678 & 68.3 & 41.7 & 44.8 & 33.6 & 20.0 \\
\hline$L(f t)$ & 589 & 609 & 1,440 & 195 & 421 & 363 & 462 & 374 & 648 & 1,460 & 179 & 220 & 631 & 101 & 205 \\
\hline MFD (ft) & 703 & 744 & 1,510 & 342 & 567 & 568 & 492 & 440 & 680 & 1,620 & 285 & 463 & 697 & 145 & 276 \\
\hline $\operatorname{MFS}(\mathbf{f t} / \mathbf{f t})$ & 0.26 & 0.23 & 0.16 & 0.14 & 0.10 & 0.08 & 0.10 & 0.07 & 0.26 & 0.11 & 0.10 & 0.09 & 0.07 & 0.13 & 0.09 \\
\hline MSL (ft) & 193 & 185 & 934 & 206 & 451 & 461 & 391 & 372 & 660 & 540 & 134 & 354 & 544 & 84.0 & 212 \\
\hline MSS (ft/ft) & 0.09 & 0.06 & 0.05 & 0.01 & 0.02 & 0.02 & 0.04 & 0.03 & 0.27 & 0.33 & 0.01 & 0.04 & 0.03 & 0.08 & 0.06 \\
\hline $\mathbf{C N}$ & 67 & 68 & 66 & 82 & 82 & 82 & 82 & 82 & 82 & 82 & 69 & 69 & 69 & 69 & 69 \\
\hline Time of Concentration (hr) & 0.13 & 0.14 & 0.57 & 0.09 & 0.10 & 0.10 & 0.09 & 0.09 & 0.09 & 0.21 & 0.09 & 0.26 & 0.40 & 0.09 & 0.18 \\
\hline
\end{tabular}


The hydrologic response of the AOC watershed is displayed in Table 8. The peak discharge $\left(\mathrm{Q}_{\mathrm{p}}\right)$ values were less than the peak discharges for the undisturbed original topography at a CN value of 66 for the 1-, 2-, and 5-year rainfall events and higher for the 10- through 500year rainfall events. The $\mathrm{Q}_{\mathrm{p}}$ values generated by 1-, 2-, and 5-year rainfall events were 71\%, $72 \%$, and $53 \%$ lower than $\mathrm{Q}_{\mathrm{p}}$ values generated by the same storms in the original topography (Table 8). Storm events of after the 5-year storm all yielded higher $\mathrm{Q}_{\mathrm{p}}$ values. $\mathrm{Q}_{\mathrm{p}}$ values increased by $8 \%$ for the 10 -year storm, $36 \%$ for the 25 -year storm, $39 \%$ for the 50 -year storm, $38 \%$ for the 100 -year storm and $30 \%$ for the 500 -year storm (Table 8 ). Time of peak $\left(\mathrm{T}_{\mathrm{p}}\right)$ values were within $\pm 3 \%$ for all storm events (Table 8).

\subsubsection{Geomorphic Landform Design}

The delineated geomorphic landform design (GLD) watershed displayed in Figure 14 shows a similar overall watershed size and shape to the original topography with a total area of 524 acres, three acres larger than the original watershed. The watershed is composed of nine sub-basins that range in size from 170 acres to 7.8 acres with an average sub-basin area of 58 acres. Table 10 lists the sub-basin characteristics for the GLD watershed. The average BS of the GLD watershed, at 0.43 , is $16 \%$ lower than the original topography. AOFD values for the GLD watershed are, on average, 30\% higher than AOFD values within the original topography. Basin lengths and MFDs for the GLD watershed are on average 9\% and 6\% larger than the original topography. Average MFS and MSL both decreased by $13 \%$ and $12 \%$ respectively with the average MSS increasing by $7 \%$ when compared to the original topography. 


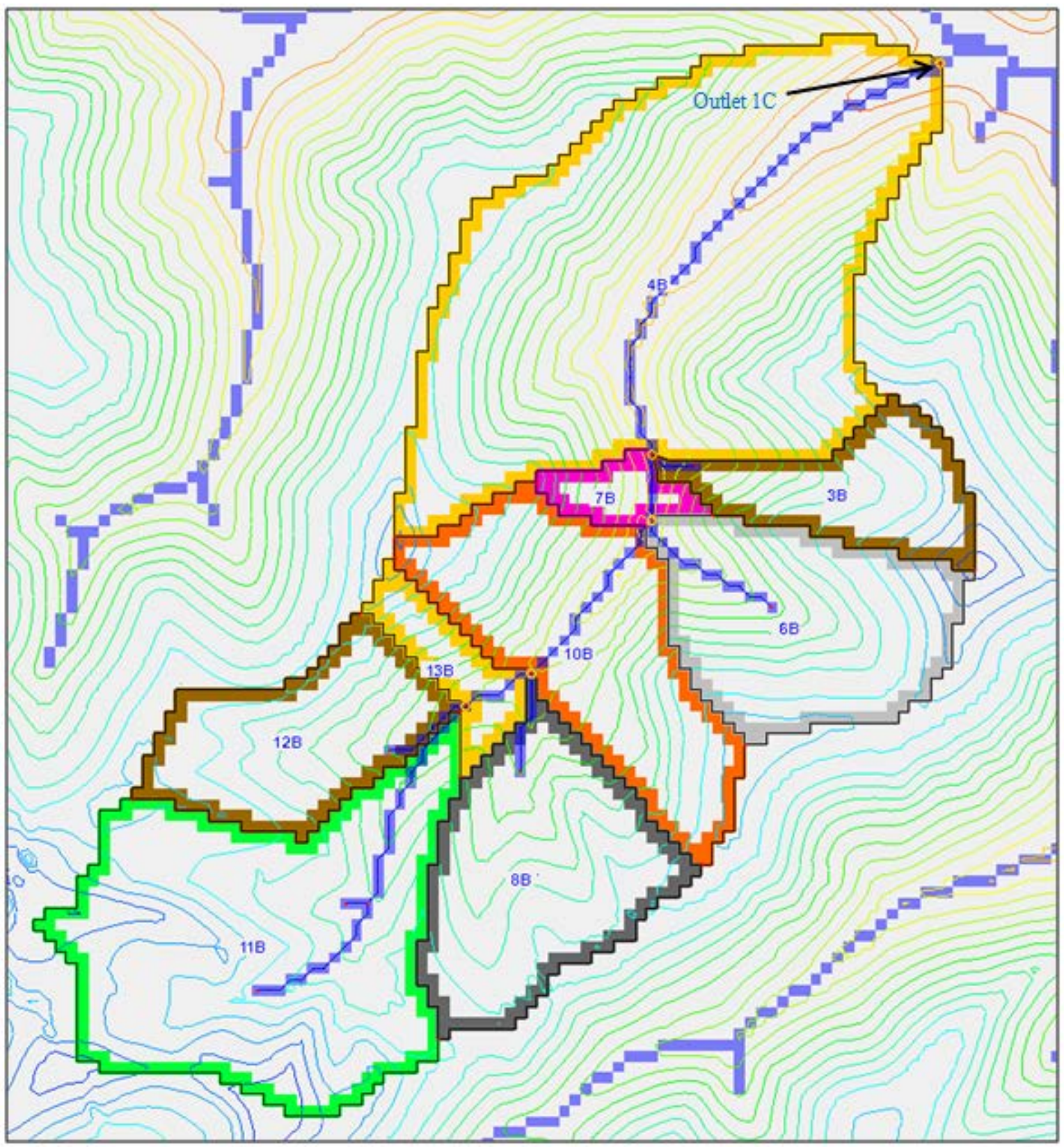

Figure 14: GLD topography delineated watershed and watershed sub-basins 
Table 10: GLD topography basin data

\begin{tabular}{|c|c|c|c|c|c|c|c|c|c|}
\hline & 4B & 3B & 7B & 6B & 10B & 13B & 8B & 11B & 12B \\
\hline Area (ac) & 170 & 27.3 & 7.77 & 52.3 & 59.1 & 12.6 & 54.1 & 102 & 38.9 \\
\hline Basin & & & & & & & & & \\
\hline $\begin{array}{l}\text { Slope } \\
\text { (ft/ft) }\end{array}$ & 0.51 & 0.42 & 0.59 & 0.45 & 0.48 & 0.43 & 0.32 & 0.31 & 0.34 \\
\hline $\begin{array}{c}\text { AOFD } \\
\text { (ft) }\end{array}$ & 665 & 1170 & 280 & 628 & 690 & 457 & 984 & 717 & 804 \\
\hline$L(f t)$ & 4700 & 2210 & 754 & 2163 & 2270 & 1180 & 2450 & 3420 & 2240 \\
\hline MFD (ft) & 5350 & 2390 & 938 & 2584 & 3040 & 1380 & 2680 & 4300 & 2400 \\
\hline $\begin{array}{l}\text { MFS } \\
\text { (ft/ft) }\end{array}$ & 0.16 & 0.35 & 0.51 & 0.30 & 0.20 & 0.37 & 0.16 & 0.14 & 0.19 \\
\hline MSL (ft) & 3650 & 319 & 361 & 1075 & 1240 & 421 & 680 & 2610 & 625 \\
\hline $\begin{array}{l}\text { MSS } \\
(\mathbf{f t} / \mathbf{f t})\end{array}$ & 0.07 & 0.22 & 0.03 & 0.23 & 0.07 & 0.12 & 0.15 & 0.14 & 0.15 \\
\hline
\end{tabular}

Note: AOFD is average overland flow, $\mathrm{L}$ is basin length, MFD is maximum flow distance, MFS is maximum flow slope, MSL is maximum stream length and MSS is maximum stream slope.

Runoff results for the GLD during mining indicate that the GLD watershed will experience smaller peak discharge values than the original undisturbed watershed with little to no difference in total runoff volume (Table 11). Precipitation values were entered into TR-55 in accordance with the values from the NRCS (Table 2). 
Table 11: Hydrograph data for outlet 1C of GLD topography during mining $(\mathrm{CN}=84)$

\begin{tabular}{cccc}
\hline $\begin{array}{c}\text { Rainfall } \\
\text { Return Period } \\
(\mathbf{y r})\end{array}$ & $\begin{array}{c}\text { Peak Discharge } \\
\text { (cfs) }\end{array}$ & $\begin{array}{c}\text { Time of Peak } \\
(\mathbf{m i n})\end{array}$ & $\begin{array}{c}\text { Discharge } \\
\text { Volume (ft' }\end{array}$ \\
\hline 1 & 521 & 732 & $1.82 \times 10^{6}$ \\
2 & 686 & 732 & $2.34 \times 10^{6}$ \\
5 & 1037 & 732 & $3.43 \times 10^{6}$ \\
10 & 1369 & 732 & $4.45 \times 10^{6}$ \\
25 & 1725 & 732 & $5.53 \times 10^{6}$ \\
50 & 1904 & 732 & $6.08 \times 10^{6}$ \\
100 & 2205 & 732 & $6.98 \times 10^{6}$ \\
500 & 3,225 & 726 & $9.07 \times 10^{6}$ \\
\hline
\end{tabular}

The results of modeling the GLD topography at a CN value of 67 are displayed below (Table 12). These values represent the short-term ( $<5$ years) post-mining hydrologic response of the watershed. When modeled for post-mining peak discharge values generated by the GLD watershed decreased by an average of $75 \%$ with the maximum difference occurring at the 1-year return period storm which saw an $89 \%$ decrease in flow rate (Table 12). Total discharge volume decreased by an average of $54 \%$ with the maximum difference occurring at the 1-year return period which saw a $71 \%$ decrease in total discharge volume (Table 12). 
Table 12: Hydrograph data for outlet 1C of GLD topography for post-mining conditions $(\mathrm{CN}=67)$

\begin{tabular}{|c|c|c|c|}
\hline $\begin{array}{c}\text { Rainfall } \\
\text { Return Period } \\
\text { (yr) }\end{array}$ & $\begin{array}{c}\text { Peak Discharge } \\
\text { (cfs) }\end{array}$ & $\begin{array}{c}\text { Time of Peak } \\
\text { (min) }\end{array}$ & $\begin{array}{c}\text { Discharge Volume } \\
\left(\mathbf{f t}^{3}\right)\end{array}$ \\
\hline 1 & 56.7 & 750 & $5.20 \times 10^{5}$ \\
\hline 2 & 105 & 744 & $8.02 \times 10^{5}$ \\
\hline 5 & 238 & 744 & $1.47 \times 10^{6}$ \\
\hline 10 & 372 & 744 & $2.16 \times 10^{6}$ \\
\hline 25 & 542 & 738 & $2.94 \times 10^{6}$ \\
\hline 50 & 634 & 738 & $3.35 \times 10^{6}$ \\
\hline 100 & 795 & 738 & $4.05 \times 10^{6}$ \\
\hline 500 & 1,383 & 732 & $5.71 \times 10^{6}$ \\
\hline
\end{tabular}

\subsubsection{Retrofit Design}

The delineated retrofit watershed was comprised of four drainage basins ranging in size from 176 acres to 441 acres with an average size of 336 acres (Table 13). The basin slopes ranged from $0.31 \mathrm{ft} / \mathrm{ft}$ to $0.40 \mathrm{ft} / \mathrm{ft}$ with an average slope of 0.36 (Table 13). The AOFD for the basins ranged from $990 \mathrm{ft}$ to $1153 \mathrm{ft}$ with an average length of $1076 \mathrm{ft}$ (Table 13). The basin lengths for the retrofit watershed ranged in value from $4391 \mathrm{ft}$ to $7093 \mathrm{ft}$ with an average basin length of $6032 \mathrm{ft}$ (Table 13). The MFD values were between $5475 \mathrm{ft}$ and $8882 \mathrm{ft}$ with an average length of $7473 \mathrm{ft}$ (Table 13). The retrofit watershed had MFS values between 0.08 and 0.11 with an average slope of $0.10 \mathrm{ft} / \mathrm{ft}$ (Table 13). MSL values ranged from $1995 \mathrm{ft}$ for basin 4B to 6122 $\mathrm{ft}$ for basin 3B with an average length of $4415 \mathrm{ft}$ (Table 13). MSS values ranged from $0.06 \mathrm{ft} / \mathrm{ft}$ for basin $2 \mathrm{~B}$ to $0.11 \mathrm{ft} / \mathrm{ft}$ for basin 4B with an average slope of $0.08 \mathrm{ft} / \mathrm{ft}$ (Table 13). 
Table 13: Retrofit basin data

\begin{tabular}{ccccccccc}
\hline & $\begin{array}{c}\text { Area } \\
(\mathbf{a c})\end{array}$ & $\begin{array}{c}\text { Basin } \\
\text { Slope } \\
\text { (ft/ft) }\end{array}$ & $\begin{array}{c}\text { AOFD } \\
(\mathbf{f t})\end{array}$ & L (ft) & $\begin{array}{c}\text { MFD } \\
(\mathbf{f t})\end{array}$ & $\begin{array}{c}\text { MFS } \\
(\mathbf{f t} / \mathbf{f t})\end{array}$ & $\begin{array}{c}\text { MSL } \\
(\mathbf{f t})\end{array}$ & $\begin{array}{c}\text { MSS } \\
(\mathbf{f t} / \mathbf{f t})\end{array}$ \\
\hline 1B & 384 & 0.36 & 1153 & 7093 & 8882 & 0.08 & 5066 & 0.08 \\
2B & 349 & 0.40 & 1038 & 5661 & 6996 & 0.11 & 4477 & 0.06 \\
3B & 441 & 0.37 & 990 & 6985 & 8537 & 0.09 & 6122 & 0.07 \\
4B & 176 & 0.31 & 1122 & 4391 & 5475 & 0.10 & 1995 & 0.11
\end{tabular}

Note: AOFD is average overland flow, $\mathrm{L}$ is basin length, MFD is maximum flow distance, MFS is maximum flow slope, MSL is maximum stream length and MSS is maximum stream slope.



Figure 15: Delineated retrofit watershed 
The peak discharge, time of peak, and discharge volume for all four basins modeled for during-mining, post-mining short term ( $<5$ years), and post-mining long term ( $>5$ years) are modeled in Table 16, Table 18, and Table 20 respectively. Basin 2B of the retrofit design drains to the same outlet as the previous designs. However, basin $2 \mathrm{~B}$ is significantly smaller than the previous watersheds (33\% smaller than the original and GLD watersheds, 34\% smaller than the AOC watershed, and 28\% smaller than the detention pond watershed). This reduction in basin size correlates with a reduction in peak discharge values and runoff volume values 
Table 14: Hydrograph Data for retrofit design for during-mining conditions (CN=84)

\begin{tabular}{|c|c|c|c|c|c|c|c|c|c|c|c|c|}
\hline \multirow[b]{2}{*}{$\begin{array}{c}\text { Rainfall } \\
\text { Return } \\
\text { Period } \\
\text { (yr) }\end{array}$} & \multicolumn{3}{|c|}{ Basin 1B* } & \multicolumn{3}{|c|}{ Basin 2B* } & \multicolumn{3}{|c|}{ Basin 3B* } & \multicolumn{3}{|c|}{ Basin 4B* } \\
\hline & $\begin{array}{c}\text { Peak } \\
\text { Discharge } \\
\left(\mathbf{f t}^{3} / \mathbf{s e c}\right)\end{array}$ & $\begin{array}{l}\text { Time } \\
\text { of } \\
\text { Peak } \\
\text { (min) }\end{array}$ & $\begin{array}{c}\text { Discharge } \\
\text { Volume } \\
\left(\mathbf{f t}^{3}\right)\end{array}$ & $\begin{array}{c}\text { Peak } \\
\text { Discharge } \\
\left(\mathbf{f t}^{3} / \mathbf{s e c}\right)\end{array}$ & $\begin{array}{c}\text { Time } \\
\text { of } \\
\text { Peak } \\
\text { (min) }\end{array}$ & $\begin{array}{c}\text { Discharge } \\
\text { Volume } \\
\left(\mathbf{f t}^{3}\right)\end{array}$ & $\begin{array}{c}\text { Peak } \\
\text { Discharge } \\
\left(\mathbf{f t}^{3} / \mathbf{s e c}\right)\end{array}$ & $\begin{array}{c}\text { Time } \\
\text { of } \\
\text { Peak } \\
\text { (min) }\end{array}$ & $\begin{array}{c}\text { Discharge } \\
\text { Volume } \\
\left(\mathbf{f t}^{3}\right)\end{array}$ & $\begin{array}{c}\text { Peak } \\
\text { Discharge } \\
\left(\mathbf{f t}^{3} / \mathbf{s e c}\right)\end{array}$ & $\begin{array}{c}\text { Time } \\
\text { of } \\
\text { Peak } \\
\text { (min) }\end{array}$ & $\begin{array}{c}\text { Discharge } \\
\text { Volume } \\
\left(\mathbf{f t}^{3}\right)\end{array}$ \\
\hline 1 & 264 & 750 & $1.32 \times 10^{6}$ & 262 & 744 & $1.20 \times 10^{6}$ & 303 & 750 & $1.51 \times 10^{6}$ & 147 & 738 & $6.03 \times 10^{5}$ \\
\hline 2 & 352 & 750 & $1.70 \times 10^{6}$ & 345 & 744 & $1.55 \times 10^{6}$ & 403 & 750 & $1.95 \times 10^{6}$ & 193 & 738 & $7.75 \times 10^{5}$ \\
\hline 5 & 538 & 750 & $2.49 \times 10^{6}$ & 521 & 744 & $2.27 \times 10^{6}$ & 617 & 750 & $2.86 \times 10^{6}$ & 293 & 738 & $1.14 \times 10^{6}$ \\
\hline 10 & 715 & 750 & $3.23 \times 10^{6}$ & 688 & 744 & $2.94 \times 10^{6}$ & 820 & 750 & $3.70 \times 10^{6}$ & 387 & 738 & $1.47 \times 10^{6}$ \\
\hline 25 & 905 & 750 & $4.01 \times 10^{6}$ & 867 & 744 & $3.66 \times 10^{6}$ & 1,038 & 750 & $4.60 \times 10^{6}$ & 488 & 738 & $1.83 \times 10^{6}$ \\
\hline 50 & 1,001 & 750 & $4.41 \times 10^{6}$ & 957 & 744 & $4.02 \times 10^{6}$ & 1,147 & 750 & $5.06 \times 10^{6}$ & 538 & 738 & $2.01 \times 10^{6}$ \\
\hline 100 & 1,165 & 744 & $5.07 \times 10^{6}$ & 1,108 & 744 & $4.62 \times 10^{6}$ & 1,337 & 744 & $5.81 \times 10^{6}$ & 624 & 738 & $2.31 \times 10^{6}$ \\
\hline 500 & 1,533 & 744 & $6.49 \times 10^{6}$ & 1,434 & 744 & $5.91 \times 10^{6}$ & 1,758 & 744 & $7.44 \times 10^{6}$ & 807 & 738 & $2.96 \times 10^{6}$ \\
\hline
\end{tabular}

*Basins defined in Figure 
Table 15: Hydrograph Data for retrofit design for short-term post-mining conditions (CN=67)

\begin{tabular}{|c|c|c|c|c|c|c|c|c|c|c|c|c|}
\hline & \multicolumn{3}{|c|}{ Basin 1B* } & \multicolumn{3}{|c|}{ Basin 2B* } & \multicolumn{3}{|c|}{ Basin 3B* } & \multicolumn{3}{|c|}{ Basin 4B* } \\
\hline $\begin{array}{c}\text { Rainfall } \\
\text { Return } \\
\text { Period } \\
\text { (yr) }\end{array}$ & $\begin{array}{c}\text { Peak } \\
\text { Discharge } \\
\left(\mathbf{f t}^{3} / \mathbf{s e c}\right)\end{array}$ & $\begin{array}{c}\text { Time } \\
\text { of } \\
\text { Peak } \\
\text { (min) }\end{array}$ & $\begin{array}{c}\text { Discharge } \\
\text { Volume } \\
\left(\mathbf{f t}^{3}\right)\end{array}$ & $\begin{array}{c}\text { Peak } \\
\text { Discharge } \\
\left(\mathbf{f t}^{3} / \mathbf{s e c}\right)\end{array}$ & $\begin{array}{c}\text { Time } \\
\text { of } \\
\text { Peak } \\
\text { (min) }\end{array}$ & $\begin{array}{c}\text { Discharge } \\
\text { Volume } \\
\left(\mathbf{f t}^{3}\right)\end{array}$ & $\begin{array}{c}\text { Peak } \\
\text { Discharge } \\
\left(\mathbf{f t}^{3} / \mathbf{s e c}\right)\end{array}$ & $\begin{array}{c}\text { Time } \\
\text { of } \\
\text { Peak } \\
\text { (min) }\end{array}$ & $\begin{array}{c}\text { Discharge } \\
\text { Volume } \\
\left(\mathbf{f t}^{3}\right)\end{array}$ & $\begin{array}{c}\text { Peak } \\
\text { Discharge } \\
\left(\mathbf{f t}^{3} / \mathbf{s e c}\right)\end{array}$ & $\begin{array}{c}\text { Time } \\
\text { of } \\
\text { Peak } \\
\text { (min) }\end{array}$ & $\begin{array}{c}\text { Discharge } \\
\text { Volume } \\
\left(\mathbf{f t}^{3}\right)\end{array}$ \\
\hline 1 & 32.2 & 792 & $3.73 \times 10^{5}$ & 33.9 & 780 & $3.40 \times 10^{5}$ & 36.9 & 792 & $4.27 \times 10^{5}$ & 18.0 & 768 & $1.73 \times 10^{5}$ \\
\hline 2 & 58.2 & 780 & $5.76 \times 10^{5}$ & 61.7 & 768 & $5.25 \times 10^{5}$ & 66.7 & 780 & $6.61 \times 10^{5}$ & 33.1 & 762 & $2.66 \times 10^{5}$ \\
\hline 5 & 131 & 780 & $1.06 \times 10^{6}$ & 141 & 768 & $9.69 \times 10^{5}$ & 151 & 780 & $1.22 \times 10^{6}$ & 74.8 & 762 & $4.90 \times 10^{5}$ \\
\hline 10 & 203 & 780 & $1.56 \times 10^{6}$ & 214 & 768 & $1.42 \times 10^{6}$ & 233 & 780 & $1.79 \times 10^{6}$ & 115 & 762 & $7.19 \times 10^{5}$ \\
\hline 25 & 287 & 780 & $2.13 \times 10^{6}$ & 300 & 768 & $1.94 \times 10^{6}$ & 329 & 780 & $2.45 \times 10^{6}$ & 161 & 762 & $9.80 \times 10^{5}$ \\
\hline 50 & 332 & 780 & $2.43 \times 10^{6}$ & 346 & 768 & $2.22 \times 10^{6}$ & 381 & 780 & $2.79 \times 10^{6}$ & 186 & 762 & $1.12 \times 10^{6}$ \\
\hline 100 & 410 & 780 & $2.94 \times 10^{6}$ & 425 & 768 & $2.68 \times 10^{6}$ & 470 & 780 & $3.37 \times 10^{6}$ & 228 & 762 & $1.35 \times 10^{6}$ \\
\hline 500 & 587 & 780 & $4.09 \times 10^{6}$ & 620 & 762 & $3.74 \times 10^{6}$ & 673 & 780 & $4.69 \times 10^{6}$ & 330 & 756 & $1.88 \times 10^{6}$ \\
\hline
\end{tabular}


Table 16: Hydrograph Data for retrofit design for long-term post-mining conditions $(\mathrm{CN}=60)$

\begin{tabular}{|c|c|c|c|c|c|c|c|c|c|c|c|c|}
\hline & \multicolumn{3}{|c|}{ Basin 1B } & \multicolumn{3}{|c|}{ Basin 2B } & \multicolumn{3}{|c|}{ Basin 3B } & \multicolumn{3}{|c|}{ Basin 4B } \\
\hline $\begin{array}{c}\text { Rainfall } \\
\text { Return } \\
\text { Period } \\
\text { (yr) }\end{array}$ & $\begin{array}{c}\text { Peak } \\
\text { Discharge } \\
\left(\mathbf{f t}^{3} / \mathbf{s e c}\right)\end{array}$ & $\begin{array}{c}\text { Time } \\
\text { of } \\
\text { Peak } \\
\text { (min) }\end{array}$ & $\begin{array}{c}\text { Discharge } \\
\text { Volume } \\
\left(\mathbf{f t}^{3}\right)\end{array}$ & $\begin{array}{c}\text { Peak } \\
\text { Discharge } \\
\left(\mathbf{f t}^{3} / \mathbf{s e c}\right)\end{array}$ & $\begin{array}{c}\text { Time } \\
\text { of } \\
\text { Peak } \\
\text { (min) }\end{array}$ & $\begin{array}{c}\text { Discharge } \\
\text { Volume } \\
\left(\mathbf{f t}^{3}\right)\end{array}$ & $\begin{array}{c}\text { Peak } \\
\text { Discharge } \\
\left(\mathbf{f t}^{3} / \mathbf{s e c}\right)\end{array}$ & $\begin{array}{c}\text { Time } \\
\text { of } \\
\text { Peak } \\
\text { (min) }\end{array}$ & $\begin{array}{c}\text { Discharge } \\
\text { Volume } \\
\left(\mathbf{f t}^{3}\right)\end{array}$ & $\begin{array}{c}\text { Peak } \\
\text { Discharge } \\
\left.\text { (ft }{ }^{3} / \mathbf{s e c}\right)\end{array}$ & $\begin{array}{c}\text { Time } \\
\text { of } \\
\text { Peak } \\
\text { (min) }\end{array}$ & $\begin{array}{c}\text { Discharge } \\
\text { Volume } \\
\left(\mathbf{f t}^{3}\right)\end{array}$ \\
\hline 1 & 8.39 & 816 & $1.62 \times 10^{5}$ & 8.35 & 792 & $1.48 \times 10^{5}$ & 9.99 & 804 & $1.85 \times 10^{5}$ & 4.60 & 792 & $7.47 \times 10^{4}$ \\
\hline 2 & 18.44 & 804 & $2.94 \times 10^{5}$ & 19.1 & 780 & $2.69 \times 10^{5}$ & 21.5 & 804 & $3.36 \times 10^{5}$ & 10.8 & 780 & $1.35 \times 10^{5}$ \\
\hline 5 & 54.5 & 792 & $6.43 \times 10^{5}$ & 59.6 & 780 & $5.90 \times 10^{5}$ & 62.9 & 780 & $7.38 \times 10^{5}$ & 31.9 & 780 & $2.95 \times 10^{5}$ \\
\hline 10 & 104 & 792 & $1.04 \times 10^{6}$ & 112 & 780 & $9.50 \times 10^{5}$ & 122 & 780 & $1.19 \times 10^{6}$ & 62.5 & 768 & $4.75 \times 10^{5}$ \\
\hline 25 & 165 & 792 & $1.50 \times 10^{6}$ & 177 & 780 & $1.38 \times 10^{6}$ & 195 & 780 & $1.73 \times 10^{6}$ & 100 & 768 & $6.89 \times 10^{5}$ \\
\hline 50 & 194 & 792 & $1.75 \times 10^{6}$ & 207 & 780 & $1.60 \times 10^{6}$ & 232 & 780 & $2.01 \times 10^{6}$ & 119 & 768 & $8.03 \times 10^{5}$ \\
\hline 100 & 245 & 792 & $2.18 \times 10^{6}$ & 261 & 780 & $2.00 \times 10^{6}$ & 298 & 780 & $2.51 \times 10^{6}$ & 151 & 768 & $1.00 \times 10^{6}$ \\
\hline 500 & 369 & 792 & $3.21 \times 10^{6}$ & 404 & 768 & $2.93 \times 10^{6}$ & 458 & 780 & $3.70 \times 10^{6}$ & 230 & 768 & $1.47 \times 10^{6}$ \\
\hline
\end{tabular}




\subsubsection{Detention Pond Design}

The designed watershed has an area of 531 acres and is comprised of four separate subbasins. The largest basin, basin 17B, is 344 acres and is largely unaffected by the mining and subsequent reclamation. Basin 12B has an area of 77 acres and feeds into the first drainage basin at 1425 feet which is designed to have a capacity of 1.19 ac- $\mathrm{ft}$ when full. Basin 16B has an area of 38 acres and feeds into the second drainage basin which is located at 1260 feet and has a capacity of 0.19 ac-ft when full. Basin 14B has an area of 68 acres and feeds into the third drainage basin which is located at 1245 feet and has a capacity of 2.09 ac-ft when full (Figure 16).

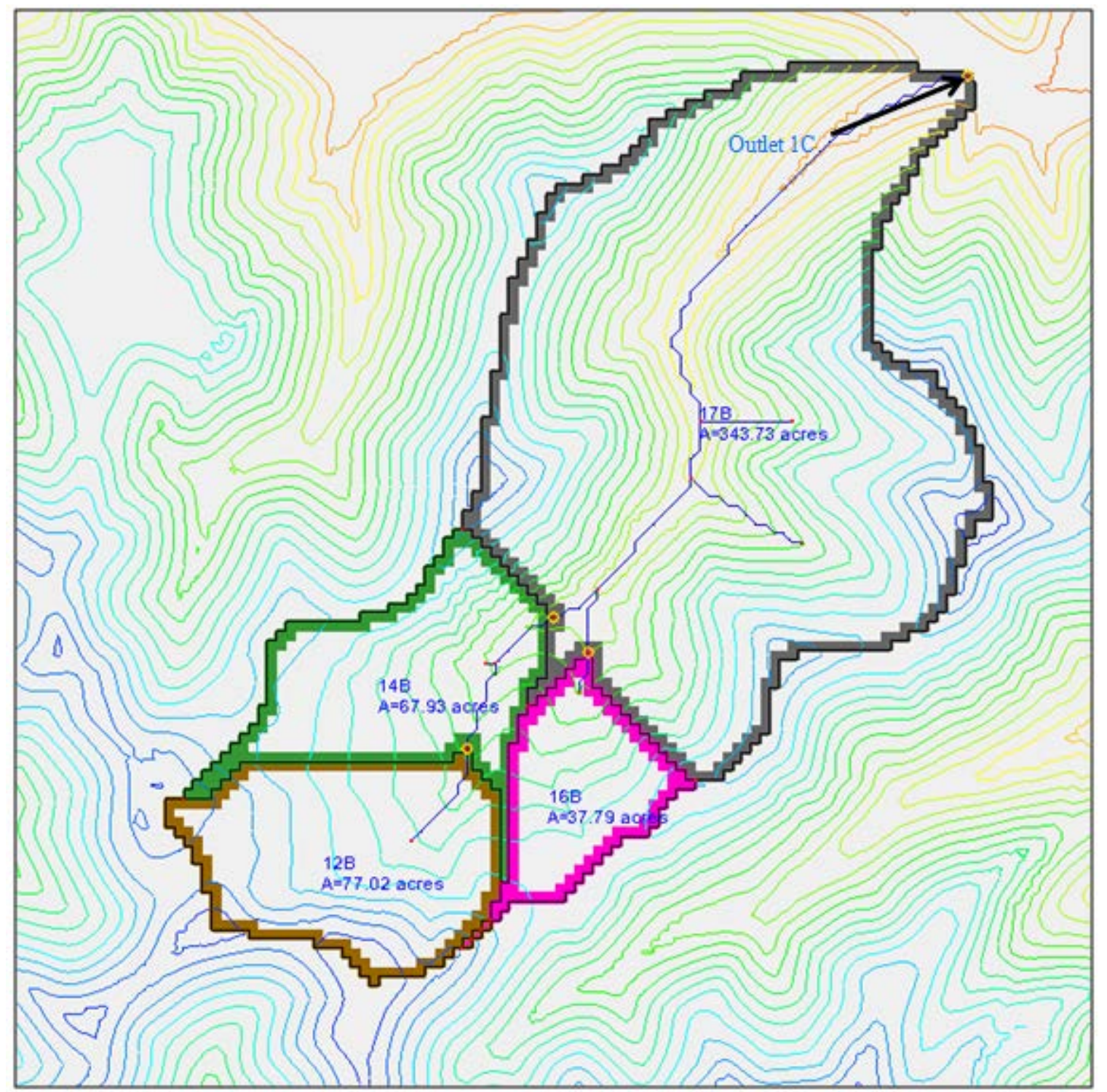

Figure 16: Designed watershed with detention pond sub-basins delineated 
Additional basin data including average overland flow (AOFD), basin length (L), maximum flow distance (MFD), maximum flow slope (MFS), maximum stream length (MSL), and maximum stream slope (MSS) can be found in Table 17 below.

Table 17: Detention pond watershed data acquired from WMS

\begin{tabular}{ccccc}
\hline & 17B* & 14B* & 16B* & 12B* \\
\hline $\begin{array}{c}\text { Area (ac) } \\
\text { Basin } \\
\text { Slope } \\
\text { (ft/ft) }\end{array}$ & 344 & 68 & 38 & 77 \\
$\begin{array}{c}\text { AOFD } \\
\text { (ft) }\end{array}$ & 666 & 846 & 942 & 1026 \\
$\begin{array}{c}\text { L (ft) } \\
\text { MFD (ft) }\end{array}$ & 7607 & 2529 & 2648 & 2848 \\
$\begin{array}{c}\text { MFS } \\
\text { (ft/ft) }\end{array}$ & 0.11 & 0.18 & 0.21 & 0.17 \\
\hline $\begin{array}{l}\text { MSL (ft) } \\
\text { MSS }\end{array}$ & 6136 & 1288 & 341 & 894 \\
(ft/ft) & 0.06 & 0.13 & 0.14 & 0.17 \\
\hline
\end{tabular}

*Basins defined in Figure 16. Note: AOFD is average overland flow, L is basin length, MFD is maximum flow distance, MFS is maximum flow slope, MSL is maximum stream length and MSS is maximum stream slope.

The maximum peak discharge and maximum discharge volume at a $\mathrm{CN}$ of 84 were seen at the 500-year return period storm event with values of 2,188 $\mathrm{ft}^{3} / \mathrm{sec}$ and $9.21 \times 106 \mathrm{ft}^{3}$ respectively (Table 18). 
Table 18: Hydrograph data for the designed watershed during mining $(\mathrm{CN}=84)$

\begin{tabular}{cccc}
\hline $\begin{array}{c}\text { Rainfall Return } \\
\text { Period (yr) }\end{array}$ & $\begin{array}{c}\text { Peak Discharge } \\
(\mathbf{c f s})\end{array}$ & $\begin{array}{c}\text { Time of Peak } \\
(\mathbf{m i n})\end{array}$ & $\begin{array}{c}\text { Discharge Volume } \\
\left(\boldsymbol{f t}^{\mathbf{3}} \mathbf{)}\right.\end{array}$ \\
\hline 1 & 440 & 726 & $1.85 \times 10^{6}$ \\
2 & 572 & 726 & $2.39 \times 10^{6}$ \\
5 & 850 & 726 & $3.52 \times 10^{6}$ \\
10 & 1,104 & 726 & $4.58 \times 10^{6}$ \\
25 & 1,370 & 726 & $5.69 \times 10^{6}$ \\
50 & 1,498 & 726 & $6.25 \times 10^{6}$ \\
100 & 1,725 & 726 & $7.19 \times 10^{6}$ \\
500 & 2,188 & 720 & $9.21 \times 10^{6}$ \\
\hline
\end{tabular}

The hydrologic response of the designed watershed at a CN value of 67 is shown in Table 19 below. 
Table 19: Hydrograph data for the outlet of the designed watershed for short-term postmining conditions $(\mathrm{CN}=67)$

\begin{tabular}{cccc}
\hline $\begin{array}{c}\text { Rainfall Return } \\
\text { Period (yr) }\end{array}$ & $\begin{array}{c}\text { Peak Discharge } \\
\text { (cfs) }\end{array}$ & $\begin{array}{c}\text { Time of Peak } \\
(\mathbf{m i n})\end{array}$ & $\begin{array}{c}\text { Discharge Volume } \\
\left(\boldsymbol{f t}^{\mathbf{3}}\right)\end{array}$ \\
\hline 1 & 36 & 756 & $4.54 \times 10^{5}$ \\
2 & 63 & 750 & $6.72 \times 10^{5}$ \\
5 & 136 & 747 & $1.17 \times 10^{6}$ \\
10 & 216 & 747 & $1.70 \times 10^{6}$ \\
25 & 308 & 747 & $2.29 \times 10^{6}$ \\
50 & 356 & 747 & $2.60 \times 10^{6}$ \\
100 & 439 & 747 & $3.13 \times 10^{6}$ \\
500 & 625 & 744 & $4.32 \times 10^{6}$ \\
& & & \\
\hline
\end{tabular}

The results generated for the designed watershed for long-term post-mining conditions are displayed in Table 27. 
Table 20: Hydrograph data for the outlet of the designed watershed for long-term postmining conditions $(\mathrm{CN}=60)$

\begin{tabular}{cccc}
\hline $\begin{array}{c}\text { Rainfall Return } \\
\text { Period (yr) }\end{array}$ & $\begin{array}{c}\text { Peak Discharge } \\
(\mathbf{c f s})\end{array}$ & $\begin{array}{c}\text { Time of Peak } \\
(\mathbf{m i n})\end{array}$ & $\begin{array}{c}\text { Discharge Volume } \\
\left(\boldsymbol{f t}^{\mathbf{3}}\right)\end{array}$ \\
\hline 1 & 9 & 777 & $2.35 \times 10^{5}$ \\
2 & 20 & 762 & $3.77 \times 10^{5}$ \\
5 & 59 & 759 & $7.43 \times 10^{5}$ \\
10 & 109 & 756 & $1.15 \times 10^{6}$ \\
25 & 173 & 756 & $1.63 \times 10^{6}$ \\
50 & 207 & 756 & $1.88 \times 10^{6}$ \\
100 & 269 & 753 & $2.33 \times 10^{6}$ \\
500 & 412 & 753 & $3.37 \times 10^{6}$ \\
& & &
\end{tabular}

\subsection{Comparison of Reclamation Designs}

Results of the hydrologic modeling of the alternative reclamation designs were compared against the data generated for the original watershed at both a CN of 66 and a CN of 84 . Because the $\mathrm{CN}$ value of 84 was calculated using only two undisturbed watersheds in central West Virginia more emphasis was placed upon the comparisons between the hydrologic response of the undisturbed topography at a CN of 66 and the alternative reclamation designs.

\subsubsection{Comparison of Reclamation Designs to the Original Topography at $\mathbf{C N}=\mathbf{6 6}$}

The GLD for during mining conditions generated higher peak discharge and runoff volume values and lower time of peak values when compared to the original topography (Table 21). During mining conditions resulted in peak discharge values on average $340 \%$ higher, average time of peak values $1 \%$ lower, and average runoff volume values $140 \%$ higher than the original topography (Table 29). 
Table 21: Comparison between the hydrologic response of the GLD watershed (CN=84) and the original topography for during mining conditions

\begin{tabular}{ccccccc}
\hline $\begin{array}{c}\text { Storm } \\
\text { Event }\end{array}$ & \multicolumn{2}{c}{$\begin{array}{c}\text { Peak Discharge } \\
\text { (cfs) }\end{array}$} & Time of Peak (min) & \multicolumn{2}{c}{ Volume $\mathbf{( f t}^{3}$ ) } \\
Return & GLD & Original & GLD & Original & GLD & Original \\
Period & & & & & & \\
\hline 1-year & 521 & 54 & 732 & 738 & $1.82 \times 10^{6}$ & $4.69 \times 10^{5}$ \\
2-year & 686 & 104 & 732 & 738 & $2.34 \times 10^{6}$ & $7.34 \times 10^{5}$ \\
5-year & 1037 & 246 & 732 & 738 & $3.43 \times 10^{6}$ & $1.38 \times 10^{6}$ \\
10-year & 1369 & 398 & 732 & 738 & $4.45 \times 10^{6}$ & $2.04 \times 10^{6}$ \\
25-year & 1725 & 580 & 732 & 738 & $5.53 \times 10^{6}$ & $2.79 \times 10^{6}$ \\
50-year & 1904 & 678 & 732 & 738 & $6.08 \times 10^{6}$ & $3.19 \times 10^{6}$ \\
100-year & 2205 & 849 & 732 & 738 & $6.98 \times 10^{6}$ & $3.87 \times 10^{6}$ \\
500-year & 3,225 & 1,256 & 726 & 738 & $9.07 \times 10^{6}$ & $5.45 \times 10^{6}$ \\
\hline
\end{tabular}

The GLD for post-mining conditions generated peak discharge and runoff volume values that closely resembled the values generated by the original watershed (Table 22). When compared to the original, undisturbed watershed modeled at a CN value of 66, the GLD postmining values most closely matched the peak discharge values of the original topography with an average peak discharge 2\% lower and runoff volume 7\% higher than those produced by the original topography (Table 29). Average time of peak values were no different than the values for the original watershed (Table 29). 
Table 22: Comparison between the hydrologic response of the GLD watershed (CN=67) and the original topography for post-mining conditions

\begin{tabular}{ccccccc}
\hline $\begin{array}{c}\text { Storm } \\
\text { Event }\end{array}$ & $\begin{array}{c}\text { Peak Discharge } \\
\text { (cfs) }\end{array}$ & \multicolumn{2}{c}{ Time of Peak (min) } & \multicolumn{2}{c}{ Volume $\left(\mathbf{f t}^{3}\right)$} \\
$\begin{array}{c}\text { Return } \\
\text { Period }\end{array}$ & GLD & Original & GLD & Original & GLD & Original \\
\hline 1-year & 56.7 & 54 & 750 & 738 & $5.20 \times 10^{5}$ & $4.69 \times 10^{5}$ \\
2-year & 105 & 104 & 744 & 738 & $8.02 \times 10^{5}$ & $7.34 \times 10^{5}$ \\
5-year & 238 & 246 & 744 & 738 & $1.47 \times 10^{6}$ & $1.38 \times 10^{6}$ \\
10-year & 372 & 398 & 744 & 738 & $2.16 \times 10^{6}$ & $2.04 \times 10^{6}$ \\
25-year & 542 & 580 & 738 & 738 & $2.94 \times 10^{6}$ & $2.79 \times 10^{6}$ \\
50-year & 634 & 678 & 738 & 738 & $3.35 \times 10^{6}$ & $3.19 \times 10^{6}$ \\
100-year & 795 & 849 & 738 & 738 & $4.05 \times 10^{6}$ & $3.87 \times 10^{6}$ \\
500-year & 1,383 & 1,256 & 732 & 738 & $5.71 \times 10^{6}$ & $5.45 \times 10^{6}$ \\
\hline
\end{tabular}

The detention pond reclamation design generated peak discharge values that more closely resembled the original watershed values than the GLD for during mining conditions (Table 23). Average peak discharge values were 250\% higher than the peak discharge values generated by the original watershed for all rainfall return periods (Table 29). The GLD and detention pond design produced similar average runoff values. Both reclamation designs generated 140\% more runoff volume than the original topography (Table 29). Average time of peak values were 2\% lower for the detention pond design than the original topography (Table 29). 
Table 23: Comparison between the hydrologic response of the designed watershed (CN = 84) and original topography for during mining conditions

\begin{tabular}{ccccccc}
\hline $\begin{array}{c}\text { Storm } \\
\text { Event }\end{array}$ & $\begin{array}{c}\text { Peak Discharge } \\
\text { (cfs) }\end{array}$ & \multicolumn{2}{c}{$\begin{array}{c}\text { Time of Peak } \\
\text { (min) }\end{array}$} & \multicolumn{2}{c}{ Volume } \\
Return & Detention \\
Period & Pond & Original & $\begin{array}{c}\text { Detention } \\
\text { Pond }\end{array}$ & Original & $\begin{array}{c}\text { Detention } \\
\text { Pond }\end{array}$ & Original \\
\hline 1-year & 440 & 54 & 726 & 738 & $1.85 \times 10^{6}$ & $4.69 \times 10^{5}$ \\
2-year & 572 & 104 & 726 & 738 & $2.39 \times 10^{6}$ & $7.34 \times 10^{5}$ \\
5-year & 850 & 246 & 726 & 738 & $3.52 \times 10^{6}$ & $1.38 \times 10^{6}$ \\
10-year & 1,104 & 398 & 726 & 738 & $4.58 \times 10^{6}$ & $2.04 \times 10^{6}$ \\
25-year & 1,370 & 580 & 726 & 738 & $5.69 \times 10^{6}$ & $2.79 \times 10^{6}$ \\
50-year & 1,498 & 678 & 726 & 738 & $6.25 \times 10^{6}$ & $3.19 \times 10^{6}$ \\
100-year & 1,725 & 849 & 726 & 738 & $7.19 \times 10^{6}$ & $3.87 \times 10^{6}$ \\
500-year & 2,188 & 1,256 & 720 & 738 & $9.21 \times 10^{6}$ & $5.45 \times 10^{6}$ \\
\hline
\end{tabular}

The detention pond design produced lower peak discharge and total runoff volume and higher time of peak values than the original watershed for short-term ( $<5$ years) post-mining conditions (Table 24). Peak discharge values were, on average, $45 \%$ lower than values generated by the original watershed (Table 29). Average time of peak values were $1 \%$ higher and total runoff volume was 15\% lower than the original watershed (Table 29). 
Table 24: Comparison between the hydrologic response of the designed watershed (CN = 67) and original topography for short-term, post-mining conditions

\begin{tabular}{ccccccc}
\hline $\begin{array}{c}\text { Storm } \\
\text { Event }\end{array}$ & \multicolumn{2}{c}{$\begin{array}{c}\text { Peak Discharge } \\
\text { (cfs) }\end{array}$} & \multicolumn{2}{c}{$\begin{array}{c}\text { Time of Peak } \\
\text { (min) }\end{array}$} & \multicolumn{2}{c}{ Volume } \\
Return & $\begin{array}{c}\mathbf{f t}^{3} \text { ) } \\
\text { Detention }\end{array}$ & Original & $\begin{array}{c}\text { Detention } \\
\text { Pond }\end{array}$ & Original & $\begin{array}{c}\text { Detention } \\
\text { Pond }\end{array}$ & Original \\
\hline 1-year & 36 & 54 & 756 & 738 & $4.54 \times 10^{5}$ & $4.69 \times 10^{5}$ \\
2-year & 63 & 104 & 750 & 738 & $6.72 \times 10^{5}$ & $7.34 \times 10^{5}$ \\
5-year & 136 & 246 & 747 & 738 & $1.17 \times 10^{6}$ & $1.38 \times 10^{6}$ \\
10-year & 216 & 398 & 747 & 738 & $1.70 \times 10^{6}$ & $2.04 \times 10^{6}$ \\
25-year & 308 & 580 & 747 & 738 & $2.29 \times 10^{6}$ & $2.79 \times 10^{6}$ \\
50-year & 356 & 678 & 747 & 738 & $2.60 \times 10^{6}$ & $3.19 \times 10^{6}$ \\
100-year & 439 & 849 & 747 & 738 & $3.13 \times 10^{6}$ & $3.87 \times 10^{6}$ \\
500-year & 625 & 1,256 & 744 & 738 & $4.32 \times 10^{6}$ & $5.45 \times 10^{6}$ \\
\hline
\end{tabular}

The detention pond design generated even lower peak discharge and total runoff volume values than those generated by the original watershed for long-term ( $>5$ years), post-mining conditions (Table 25). Average peak discharge and total runoff volume values were $73 \%$ and $44 \%$ lower respectively (Table 29). Average time of peak values were 3\% greater than time of peak values generated by the original topography (Table 29). 
Table 25: Comparison between the hydrologic response of the designed watershed ( $\mathrm{CN}=$ 60) and original topography for long-term, post-mining conditions

\begin{tabular}{|c|c|c|c|c|c|c|}
\hline \multirow{2}{*}{$\begin{array}{l}\text { Storm } \\
\text { Event } \\
\text { Return } \\
\text { Period }\end{array}$} & \multicolumn{2}{|c|}{$\begin{array}{c}\text { Peak Discharge } \\
\text { (cfs) }\end{array}$} & \multicolumn{2}{|c|}{$\begin{array}{c}\text { Time of Peak } \\
\text { (min) }\end{array}$} & \multicolumn{2}{|c|}{ Volume $\left(\mathbf{f t}^{3}\right)$} \\
\hline & $\begin{array}{c}\text { Detention } \\
\text { Pond }\end{array}$ & Original & $\begin{array}{c}\text { Detention } \\
\text { Pond }\end{array}$ & Original & $\begin{array}{c}\text { Detention } \\
\text { Pond }\end{array}$ & Original \\
\hline 1-year & 9 & 54 & 777 & 738 & $2.35 \times 10^{5}$ & $4.69 \times 10^{5}$ \\
\hline 2-year & 20 & 104 & 762 & 738 & $3.77 \times 10^{5}$ & $7.34 \times 10^{5}$ \\
\hline 5-year & 59 & 246 & 759 & 738 & $7.43 \times 10^{5}$ & $1.38 \times 10^{6}$ \\
\hline 10-year & 109 & 398 & 756 & 738 & $1.15 \times 10^{6}$ & $2.04 \times 10^{6}$ \\
\hline 25-year & 173 & 580 & 756 & 738 & $1.63 \times 10^{6}$ & $2.79 \times 10^{6}$ \\
\hline 50-year & 207 & 678 & 756 & 738 & $1.88 \times 10^{6}$ & $3.19 \times 10^{6}$ \\
\hline 100-year & 269 & 849 & 753 & 738 & $2.33 \times 10^{6}$ & $3.87 \times 10^{6}$ \\
\hline 500-year & 412 & 1,256 & 753 & 738 & $3.37 \times 10^{6}$ & $5.45 \times 10^{6}$ \\
\hline
\end{tabular}

For during mining conditions the retrofit reclamation design generated peak discharge, time of peak, and total runoff volume values lower than those generated by the GLD or detention pond design at during mining conditions, but greater than those generated by the original watershed (Table 26). Average peak discharge and total runoff volume values were $117 \%$ and $58 \%$ greater respectively (Table 29). Average time of peak values were $1 \%$ higher than those generated by the original topography. 
Table 26: Comparison between the hydrologic response of $2 B$ of the retrofit watershed $(\mathrm{CN}=84)$ and original topography for during mining conditions

\begin{tabular}{|c|c|c|c|c|c|c|}
\hline \multirow{2}{*}{$\begin{array}{l}\text { Storm } \\
\text { Event } \\
\text { Return } \\
\text { Period }\end{array}$} & \multicolumn{2}{|c|}{$\begin{array}{c}\text { Peak Discharge } \\
\text { (cfs) }\end{array}$} & \multicolumn{2}{|c|}{$\begin{array}{c}\text { Time of Peak } \\
\text { (min) }\end{array}$} & \multicolumn{2}{|c|}{ Volume $\left(\mathrm{ft}^{3}\right)$} \\
\hline & Retrofit & Original & Retrofit & Original & Retrofit & Original \\
\hline 1-year & 262 & 54 & 744 & 738 & $1.20 \times 10^{6}$ & $4.69 \times 10^{5}$ \\
\hline 2-year & 345 & 104 & 744 & 738 & $1.55 \times 10^{6}$ & $7.34 \times 10^{5}$ \\
\hline 5-year & 521 & 246 & 744 & 738 & $2.27 \times 10^{6}$ & $1.38 \times 10^{6}$ \\
\hline 10-year & 688 & 398 & 744 & 738 & $2.94 \times 10^{6}$ & $2.04 \times 10^{6}$ \\
\hline 25-year & 867 & 580 & 744 & 738 & $3.66 \times 10^{6}$ & $2.79 \times 10^{6}$ \\
\hline 50-year & 957 & 678 & 744 & 738 & $4.02 \times 10^{6}$ & $3.19 \times 10^{6}$ \\
\hline 100-year & 1,108 & 849 & 744 & 738 & $4.62 \times 10^{6}$ & $3.87 \times 10^{6}$ \\
\hline 500-year & 1,434 & 1,256 & 744 & 738 & $5.91 \times 10^{6}$ & $5.45 \times 10^{6}$ \\
\hline
\end{tabular}

The short-term ( $<5$ years), post-mining conditions of the retrofit design produced peak discharge and runoff volume values lower and time of peak values higher than those generated by the original watershed (Table 27). Average peak discharge and total runoff volumes were $46 \%$ and $30 \%$ lower respectively while average time of peak values were $4 \%$ higher than those generated by the original watershed (Table 29). 
Table 27: Comparison between the hydrologic response of $2 \mathrm{~B}$ of the retrofit watershed $(\mathrm{CN}=67)$ and original topography for post-mining, short-term conditions

\begin{tabular}{lcccccc}
\hline $\begin{array}{l}\text { Storm } \\
\text { Event }\end{array}$ & \multicolumn{2}{c}{$\begin{array}{c}\text { Peak Discharge } \\
\text { (cfs) }\end{array}$} & \multicolumn{2}{c}{ Time of Peak } \\
(min) & \multicolumn{2}{c}{ Volume $\mathbf{( f t}^{3}$ ) } \\
$\begin{array}{c}\text { Return } \\
\text { Period }\end{array}$ & Retrofit & Original & Retrofit & Original & Retrofit & Original \\
\hline 1-year & 33.9 & 54 & 780 & 738 & $3.40 \times 10^{5}$ & $4.69 \times 10^{5}$ \\
2-year & 61.7 & 104 & 768 & 738 & $5.25 \times 10^{5}$ & $7.34 \times 10^{5}$ \\
5-year & 141 & 246 & 768 & 738 & $9.69 \times 10^{5}$ & $1.38 \times 10^{6}$ \\
10-year & 214 & 398 & 768 & 738 & $1.42 \times 10^{6}$ & $2.04 \times 10^{6}$ \\
25-year & 300 & 580 & 768 & 738 & $1.94 \times 10^{6}$ & $2.79 \times 10^{6}$ \\
50-year & 346 & 678 & 768 & 738 & $2.22 \times 10^{6}$ & $3.19 \times 10^{6}$ \\
100-year & 425 & 849 & 768 & 738 & $2.68 \times 10^{6}$ & $3.87 \times 10^{6}$ \\
500-year & 620 & 1,256 & 762 & 738 & $3.74 \times 10^{6}$ & $5.45 \times 10^{6}$ \\
\hline
\end{tabular}

Under long-term (> 5 years), post-mining conditions the retrofit design generated peak discharge and runoff volume values lower than the both the short-term conditions and the original watershed (Table 28). Time of peak values increased with respect to the short-term conditions (Table 28). Average peak discharge and total runoff volume values were $74 \%$ and 55\% lower respectively and average time of peak values were $4 \%$ higher (Table 29). 
Table 28: Comparison between the hydrologic response of $2 B$ of the retrofit watershed $(\mathrm{CN}=60)$ and original topography for post-mining, long-term conditions

\begin{tabular}{ccccccc}
\hline $\begin{array}{c}\text { Storm } \\
\text { Event }\end{array}$ & \multicolumn{2}{c}{$\begin{array}{c}\text { Peak Discharge } \\
\text { (cfs) }\end{array}$} & \multicolumn{2}{c}{$\begin{array}{c}\text { Time of Peak } \\
\text { (min) }\end{array}$} & Volume (ft ${ }^{3}$ ) \\
Return & Retrofit & Original & Retrofit & Original & Retrofit & Original \\
Period & & & & & & \\
\hline 1-year & 8.35 & 54 & 792 & 738 & $1.48 \times 10^{5}$ & $4.69 \times 10^{5}$ \\
2-year & 19.1 & 104 & 780 & 738 & $2.69 \times 10^{5}$ & $7.34 \times 10^{5}$ \\
5-year & 59.6 & 246 & 780 & 738 & $5.90 \times 10^{5}$ & $1.38 \times 10^{6}$ \\
10-year & 112 & 398 & 780 & 738 & $9.50 \times 10^{5}$ & $2.04 \times 10^{6}$ \\
25-year & 177 & 580 & 780 & 738 & $1.38 \times 10^{6}$ & $2.79 \times 10^{6}$ \\
50-year & 207 & 678 & 780 & 738 & $1.60 \times 10^{6}$ & $3.19 \times 10^{6}$ \\
100-year & 261 & 849 & 780 & 738 & $2.00 \times 10^{6}$ & $3.87 \times 10^{6}$ \\
500-year & 404 & 1,256 & 768 & 738 & $2.93 \times 10^{6}$ & $5.45 \times 10^{6}$ \\
\hline
\end{tabular}

Exact percent difference values between each reclamation design and the original watershed at $\mathrm{CN}=66$ for individual storm event return periods can be found in Appendix B. 
Table 29: Average percent difference between original topography at $\mathrm{CN}=66$ and various reclamation designs for peak discharge, time of peak, and total runoff averaged over all rainfall return periods

\begin{tabular}{|c|c|c|c|c|}
\hline & Condition & GLD & Detention Pond & Retrofit* \\
\hline \multirow{2}{*}{\multicolumn{5}{|c|}{ Average Peak }} \\
\hline & & & & \\
\hline \multirow{4}{*}{$\begin{array}{l}\text { Discharge } \\
\text { Difference }\end{array}$} & SR & $-2 \%$ & $-45 \%$ & $-46 \%$ \\
\hline & & & & \\
\hline & LR & $-2 \%$ & $-73 \%$ & $-74 \%$ \\
\hline & $\mathrm{DM}$ & $-1 \%$ & $-2 \%$ & $1 \%$ \\
\hline \multirow{3}{*}{$\begin{array}{l}\text { Average Time of } \\
\text { Peak Difference }\end{array}$} & SR & $0 \%$ & $1 \%$ & $4 \%$ \\
\hline & LR & $0 \%$ & $3 \%$ & $6 \%$ \\
\hline & $\mathrm{DM}$ & $140 \%$ & $140 \%$ & $58 \%$ \\
\hline \multirow{2}{*}{$\begin{array}{c}\text { Average Total } \\
\text { Runoff Difference }\end{array}$} & SR & $7 \%$ & $-15 \%$ & $-30 \%$ \\
\hline & $\mathrm{LR}$ & $7 \%$ & $-44 \%$ & $-55 \%$ \\
\hline
\end{tabular}

Note: DM=during mining; SR = short-term reclaimed $(<5$ years $) ; \mathrm{LR}=$ long-term reclaimed $(>5$ years). The retrofit reclamation design has a smaller drainage basin discharging to outlet $1 \mathrm{C}$ than the other two reclamation designs.

These results indicate that the GLD may be the most suitable design for the reclamation of the mountaintop removal mine site being investigated. Higher peak discharge values will likely produce adverse erosion at the outlet, but higher total runoff volumes will produce similar adverse erosion occurrences. The detention pond and retrofit design appear to perform better than the GLD for during-mining conditions in regards to peak discharge, however for postmining conditions the two designs generate both peak discharge and total runoff volumes considerably lower than the original topography. This decrease would likely cause sedimentation that could alter the hydrologic response of the watersheds in unpredictable ways. 


\subsubsection{Comparison of the Reclamation Designs to the Original Topography at $\mathrm{CN}=84$}

Under during mining conditions the GLD generated peak discharge, time of peak, and total runoff volume values similar to the original watershed for all rainfall return periods (Table 30). Average peak discharge values were $10 \%$ lower than those produced by the original watershed (Table 38). Average time of peak values were $1 \%$ higher and average total runoff volume values differed by less than $1 \%$ (Table 38 ).

Table 30: Comparison between the hydrologic response of the GLD watershed $(\mathrm{CN}=84)$ and the original topography for during mining conditions

\begin{tabular}{ccccccc}
\hline $\begin{array}{c}\text { Storm } \\
\text { Event }\end{array}$ & \multicolumn{2}{c}{$\begin{array}{c}\text { Peak Discharge } \\
\text { (cfs) }\end{array}$} & \multicolumn{2}{c}{ Time of Peak } & \multicolumn{2}{c}{ Volume $\left(\mathbf{f t}^{3}\right)$} \\
Return & GLD & Original & GLD & Original & GLD & Original \\
Period & & & & & & \\
\hline 1-year & 521 & 588 & 732 & 726 & $1.82 \times 10^{6}$ & $1.82 \times 10^{6}$ \\
2-year & 686 & 772 & 732 & 726 & $2.34 \times 10^{6}$ & $2.34 \times 10^{6}$ \\
5-year & 1037 & 1,165 & 732 & 726 & $3.43 \times 10^{6}$ & $3.43 \times 10^{6}$ \\
10-year & 1369 & 1,535 & 732 & 726 & $4.45 \times 10^{6}$ & $4.45 \times 10^{6}$ \\
25-year & 1725 & 1,932 & 732 & 726 & $5.53 \times 10^{6}$ & $5.53 \times 10^{6}$ \\
50-year & 1904 & 2,131 & 732 & 726 & $6.08 \times 10^{6}$ & $6.07 \times 10^{6}$ \\
100-year & 2205 & 2,466 & 732 & 726 & $6.98 \times 10^{6}$ & $6.98 \times 10^{6}$ \\
500-year & 3,225 & 3,209 & 726 & 726 & $9.07 \times 10^{6}$ & $8.98 \times 10^{6}$ \\
\hline
\end{tabular}

The GLD generated peak discharge and total runoff volume values lower than the values generated by the original, undisturbed watershed for post-mining conditions (Table 31). Time of peak values were increased in comparison to during mining conditions (Table 31). Average peak discharge values and total runoff volume values were $75 \%$ and 52\% lower respectively than values generated by the original watershed (Table 38). Time of peak values were $2 \%$ higher on average than time of peak values for the original watershed (Table 38). 
Table 31: Comparison between the hydrologic response of the GLD watershed (CN=67) and the original topography for post-mining conditions

\begin{tabular}{ccccccc}
\hline $\begin{array}{c}\text { Storm } \\
\text { Event }\end{array}$ & \multicolumn{2}{c}{$\begin{array}{c}\text { Peak Discharge } \\
\text { (cfs) }\end{array}$} & \multicolumn{2}{c}{ Time of Peak (min) } & \multicolumn{2}{c}{ Volume $\left(\mathbf{f t}^{3}\right.$ ) } \\
$\begin{array}{c}\text { Return } \\
\text { Period }\end{array}$ & GLD & Original & GLD & Original & GLD & Original \\
\hline 1-year & 56.7 & 588 & 750 & 726 & $5.20 \times 10^{5}$ & $1.82 \times 10^{6}$ \\
2-year & 105 & 772 & 744 & 726 & $8.02 \times 10^{5}$ & $2.34 \times 10^{6}$ \\
5-year & 238 & 1,165 & 744 & 726 & $1.47 \times 10^{6}$ & $3.43 \times 10^{6}$ \\
10-year & 372 & 1,535 & 744 & 726 & $2.16 \times 10^{6}$ & $4.45 \times 10^{6}$ \\
25-year & 542 & 1,932 & 738 & 726 & $2.94 \times 10^{6}$ & $5.53 \times 10^{6}$ \\
50-year & 634 & 2,131 & 738 & 726 & $3.35 \times 10^{6}$ & $6.07 \times 10^{6}$ \\
100-year & 795 & 2,466 & 738 & 726 & $4.05 \times 10^{6}$ & $6.98 \times 10^{6}$ \\
500-year & 1,383 & 3,209 & 732 & 726 & $5.71 \times 10^{6}$ & $8.98 \times 10^{6}$ \\
\hline
\end{tabular}

Under during mining conditions the detention pond design produced lower peak discharge and total runoff volumes than those of the original watershed (Table 32). Time of peak values were the same for all return periods except the 500-year return period where the time of peak for the detention pond was 6 minutes earlier than that of the original watershed (Table 32). Average peak discharge values were $28 \%$ lower than peak discharge values generated by the original watershed (Table 38). Average time of peak values differed by less than $1 \%$ and average total runoff volume values were $3 \%$ higher than those generated by the original watershed (Table 38). 
Table 32: Comparison between the hydrologic response of the designed watershed ( $\mathrm{CN}=$ 84) and original topography for during mining conditions

\begin{tabular}{|c|c|c|c|c|c|c|}
\hline \multirow{2}{*}{$\begin{array}{l}\text { Storm } \\
\text { Event } \\
\text { Return } \\
\text { Period }\end{array}$} & \multicolumn{2}{|c|}{$\begin{array}{c}\text { Peak Discharge } \\
\text { (cfs) }\end{array}$} & \multicolumn{2}{|c|}{$\begin{array}{c}\text { Time of Peak } \\
\text { (min) }\end{array}$} & \multicolumn{2}{|c|}{ Volume $\left(\mathrm{ft}^{3}\right)$} \\
\hline & $\begin{array}{c}\text { Detention } \\
\text { Pond }\end{array}$ & Original & $\begin{array}{c}\text { Detention } \\
\text { Pond }\end{array}$ & Original & $\begin{array}{c}\text { Detention } \\
\text { Pond }\end{array}$ & Original \\
\hline 1-year & 440 & 588 & 726 & 726 & $1.85 \times 10^{6}$ & $1.82 \times 10^{6}$ \\
\hline 2-year & 572 & 772 & 726 & 726 & $2.39 \times 10^{6}$ & $2.34 \times 10^{6}$ \\
\hline 5-year & 850 & 1,165 & 726 & 726 & $3.52 \times 10^{6}$ & $3.43 \times 10^{6}$ \\
\hline 10-year & 1,104 & 1,535 & 726 & 726 & $4.58 \times 10^{6}$ & $4.45 \times 10^{6}$ \\
\hline 25-year & 1,370 & 1,932 & 726 & 726 & $5.69 \times 10^{6}$ & $5.53 \times 10^{6}$ \\
\hline 50-year & 1,498 & 2,131 & 726 & 726 & $6.25 \times 10^{6}$ & $6.07 \times 10^{6}$ \\
\hline 100-year & 1,725 & 2,466 & 726 & 726 & $7.19 \times 10^{6}$ & $6.98 \times 10^{6}$ \\
\hline 500-year & 2,188 & 3,209 & 720 & 726 & $9.21 \times 10^{6}$ & $8.98 \times 10^{6}$ \\
\hline
\end{tabular}

Under short-term ( $<5$ years), post-mining conditions the detention pond design produced lower peak discharges, lower total runoff volumes, and increased time of peak values when compared to the original watershed (Table 33). Peak discharge values were on average $86 \%$ lower than values generated by the original watershed (Table 38). Time of peak values were on average 3\% higher than time of peak values generated by the original watershed (Table 38). Total runoff volumes were on average $62 \%$ lower than runoff volumes generated by the original watershed (Table 38). 
Table 33: Comparison between the hydrologic response of the designed watershed ( $\mathrm{CN}=$ 67) and original topography for short-term, post-mining conditions

\begin{tabular}{ccccccc}
\hline $\begin{array}{c}\text { Storm } \\
\text { Event }\end{array}$ & $\begin{array}{c}\text { Peak Discharge } \\
\mathbf{( c f s )}\end{array}$ & $\begin{array}{c}\text { Time of Peak } \\
(\mathbf{m i n})\end{array}$ \\
$\begin{array}{c}\text { Return } \\
\text { Period }\end{array}$ & $\begin{array}{c}\text { Detention } \\
\text { Pond }\end{array}$ & Original & $\begin{array}{c}\text { Detention } \\
\text { Pond }\end{array}$ & Original & $\begin{array}{c}\text { Dolume } \\
\left(\mathbf{f t}^{3}\right) \\
\text { Pontion }\end{array}$ & Original \\
\hline 1-year & 36 & 588 & 756 & 726 & $4.54 \times 10^{5}$ & $1.82 \times 10^{6}$ \\
2-year & 63 & 772 & 750 & 726 & $6.72 \times 10^{5}$ & $2.34 \times 10^{6}$ \\
5-year & 136 & 1,165 & 747 & 726 & $1.17 \times 10^{6}$ & $3.43 \times 10^{6}$ \\
10-year & 216 & 1,535 & 747 & 726 & $1.70 \times 10^{6}$ & $4.45 \times 10^{6}$ \\
25-year & 308 & 1,932 & 747 & 726 & $2.29 \times 10^{6}$ & $5.53 \times 10^{6}$ \\
50-year & 356 & 2,131 & 747 & 726 & $2.60 \times 10^{6}$ & $6.07 \times 10^{6}$ \\
100-year & 439 & 2,466 & 747 & 726 & $3.13 \times 10^{6}$ & $6.98 \times 10^{6}$ \\
500-year & 625 & 3,209 & 744 & 726 & $4.32 \times 10^{6}$ & $8.98 \times 10^{6}$ \\
\hline
\end{tabular}

Under long-term ( $>5$ years), post-mining conditions the detention pond design produced lower peak discharges, lower runoff volumes, and higher time of peak values when compared to the original topography (Table 34). Peak discharge values were on average 93\% lower, time of peak values were on average 5\% higher, and total runoff volume values were on average $74 \%$ lower than the values generated by the original topography (Table 38). 
Table 34: Comparison between the hydrologic response of the designed watershed (CN = 60) and original topography for long-term, post-mining conditions

\begin{tabular}{|c|c|c|c|c|c|c|}
\hline \multirow{2}{*}{$\begin{array}{l}\text { Storm } \\
\text { Event } \\
\text { Return } \\
\text { Period }\end{array}$} & \multicolumn{2}{|c|}{$\begin{array}{c}\text { Peak Discharge } \\
\text { (cfs) }\end{array}$} & \multicolumn{2}{|c|}{$\begin{array}{c}\text { Time of Peak } \\
\text { (min) }\end{array}$} & \multicolumn{2}{|c|}{ Volume $\left(\mathrm{ft}^{3}\right)$} \\
\hline & $\begin{array}{c}\text { Detention } \\
\text { Pond }\end{array}$ & Original & $\begin{array}{c}\text { Detention } \\
\text { Pond }\end{array}$ & Original & $\begin{array}{c}\text { Detention } \\
\text { Pond }\end{array}$ & Original \\
\hline 1-year & 9 & 588 & 777 & 726 & $2.35 \times 10^{5}$ & $1.82 \times 10^{6}$ \\
\hline 2-year & 20 & 772 & 762 & 726 & $3.77 \times 10^{5}$ & $2.34 \times 10^{6}$ \\
\hline 5-year & 59 & 1,165 & 759 & 726 & $7.43 \times 10^{5}$ & $3.43 \times 10^{6}$ \\
\hline 10-year & 109 & 1,535 & 756 & 726 & $1.15 \times 10^{6}$ & $4.45 \times 10^{6}$ \\
\hline 25-year & 173 & 1,932 & 756 & 726 & $1.63 \times 10^{6}$ & $5.53 \times 10^{6}$ \\
\hline 50-year & 207 & 2,131 & 756 & 726 & $1.88 \times 10^{6}$ & $6.07 \times 10^{6}$ \\
\hline 100-year & 269 & 2,466 & 753 & 726 & $2.33 \times 10^{6}$ & $6.98 \times 10^{6}$ \\
\hline 500-year & 412 & 3,209 & 753 & 726 & $3.37 \times 10^{6}$ & $8.98 \times 10^{6}$ \\
\hline
\end{tabular}

The retrofit design under during-mining conditions generated lower peak discharge, time of peak, and total runoff volume values for all storm event return periods when compared to the original topography (Table 35). Average peak discharge and runoff volume values were 55\% and 34\% lower respectively when compared to the original watershed values (Table 38). Time of peak values were $3 \%$ higher than the original watershed values for all return periods (Table 38). 
Table 35: Comparison between the hydrologic response of $2 \mathrm{~B}$ of the retrofit watershed $(\mathrm{CN}=84)$ and original topography for during mining conditions

\begin{tabular}{ccccccc}
\hline $\begin{array}{c}\text { Storm } \\
\text { Event }\end{array}$ & \multicolumn{2}{c}{$\begin{array}{c}\text { Peak Discharge } \\
(\mathbf{c f s})\end{array}$} & Time of Peak (min) & \multicolumn{2}{c}{ Volume (ft $\left.\mathbf{3}^{\mathbf{3}}\right)$} \\
Return & Retrofit & Original & Retrofit & Original & Retrofit & Original \\
Period & & & & & & \\
\hline 1-year & 262 & 588 & 744 & 726 & $1.20 \times 10^{6}$ & $1.82 \times 10^{6}$ \\
2-year & 345 & 772 & 744 & 726 & $1.55 \times 10^{6}$ & $2.34 \times 10^{6}$ \\
5-year & 521 & 1,165 & 744 & 726 & $2.27 \times 10^{6}$ & $3.43 \times 10^{6}$ \\
10-year & 688 & 1,535 & 744 & 726 & $2.94 \times 10^{6}$ & $4.45 \times 10^{6}$ \\
25-year & 867 & 1,932 & 744 & 726 & $3.66 \times 10^{6}$ & $5.53 \times 10^{6}$ \\
50-year & 957 & 2,131 & 744 & 726 & $4.02 \times 10^{6}$ & $6.07 \times 10^{6}$ \\
100-year & 1,108 & 2,466 & 744 & 726 & $4.62 \times 10^{6}$ & $6.98 \times 10^{6}$ \\
500-year & 1,434 & 3,209 & 744 & 726 & $5.91 \times 10^{6}$ & $8.98 \times 10^{6}$ \\
\hline
\end{tabular}

Under short-term ( $<5$ years), post-mining conditions the retrofit design generated peak discharge and total runoff volume values that were lower than the values generated by the original watershed for all return periods (Table 36). Time of peak values for the retrofit design were higher than the values generated by the original watershed for all return periods (Table 36). Average peak discharge values and total runoff volume values were $87 \%$ and $68 \%$ lower respectively than the values generated by the original topography (Table 38). Average time of peak values were 6\% higher than the values for the original topography (Table 38). 
Table 36: Comparison between the hydrologic response of $2 B$ of the retrofit watershed $(\mathrm{CN}=67)$ and original topography for post-mining, short-term conditions

\begin{tabular}{ccccccc}
\hline $\begin{array}{c}\text { Storm } \\
\text { Event }\end{array}$ & \multicolumn{2}{c}{$\begin{array}{c}\text { Peak Discharge } \\
\text { (cfs) }\end{array}$} & Time of Peak (min) & Volume $\left(\mathbf{f t}^{3}\right)$ \\
Return & Retrofit & Original & Retrofit & Original & Retrofit & Original \\
Period & & & & & & \\
\hline 1-year & 33.9 & 588 & 780 & 726 & $3.40 \times 10^{5}$ & $1.82 \times 10^{6}$ \\
2-year & 61.7 & 772 & 768 & 726 & $5.25 \times 10^{5}$ & $2.34 \times 10^{6}$ \\
5-year & 141 & 1,165 & 768 & 726 & $9.69 \times 10^{5}$ & $3.43 \times 10^{6}$ \\
10-year & 214 & 1,535 & 768 & 726 & $1.42 \times 10^{6}$ & $4.45 \times 10^{6}$ \\
25-year & 300 & 1,932 & 768 & 726 & $1.94 \times 10^{6}$ & $5.53 \times 10^{6}$ \\
50-year & 346 & 2,131 & 768 & 726 & $2.22 \times 10^{6}$ & $6.07 \times 10^{6}$ \\
100-year & 425 & 2,466 & 768 & 726 & $2.68 \times 10^{6}$ & $6.98 \times 10^{6}$ \\
500-year & 620 & 3,209 & 762 & 726 & $3.74 \times 10^{6}$ & $8.98 \times 10^{6}$ \\
\hline
\end{tabular}

Under long-term (> 5 years), post-mining conditions the retrofit design generated peak discharge and total runoff values that were lower than those generated by the original watershed for all return periods (Table 37). The retrofit design generated time of peak values that were higher than those generated by the original topography for all return periods (Table 37). Average peak discharge and runoff volume values were 93\% and 79\% lower respectively than values generated by the original topography (Table 38). Time of peak values were on average 7\% higher than time of peak values generated by the original topography (Table 38). 
Table 37: Comparison between the hydrologic response of $2 B$ of the retrofit watershed $(\mathrm{CN}=60)$ and original topography for post-mining, long-term conditions

\begin{tabular}{ccccccc}
\hline $\begin{array}{c}\text { Storm } \\
\text { Event }\end{array}$ & \multicolumn{2}{c}{$\begin{array}{c}\text { Peak Discharge } \\
\text { (cfs) }\end{array}$} & Time of Peak (min) & Volume & $\left(\mathbf{f t}^{3}\right)$ \\
Return & Retrofit & Original & Retrofit & Original & Retrofit & Original \\
Period & & & & & & \\
\hline 1-year & 8.35 & 588 & 792 & 726 & $1.48 \times 10^{5}$ & $1.82 \times 10^{6}$ \\
2-year & 19.1 & 772 & 780 & 726 & $2.69 \times 10^{5}$ & $2.34 \times 10^{6}$ \\
5-year & 59.6 & 1,165 & 780 & 726 & $5.90 \times 10^{5}$ & $3.43 \times 10^{6}$ \\
10-year & 112 & 1,535 & 780 & 726 & $9.50 \times 10^{5}$ & $4.45 \times 10^{6}$ \\
25-year & 177 & 1,932 & 780 & 726 & $1.38 \times 10^{6}$ & $5.53 \times 10^{6}$ \\
50-year & 207 & 2,131 & 780 & 726 & $1.60 \times 10^{6}$ & $6.07 \times 10^{6}$ \\
100-year & 261 & 2,466 & 780 & 726 & $2.00 \times 10^{6}$ & $6.98 \times 10^{6}$ \\
500-year & 404 & 3,209 & 768 & 726 & $2.93 \times 10^{6}$ & $8.98 \times 10^{6}$ \\
\hline
\end{tabular}

Exact percent difference values between each reclamation design and the original watershed at $\mathrm{CN}=66$ for individual storm event return periods can be found in Appendix B. 
Table 38: Average percent difference between original topography at $\mathrm{CN}=84$ and various reclamation designs for peak discharge, time of peak, and total runoff averaged over all rainfall return periods

\begin{tabular}{|c|c|c|c|c|}
\hline & Condition & GLD & Detention Pond & Retrofit* \\
\hline \multirow{2}{*}{\multicolumn{5}{|c|}{ Average Peak }} \\
\hline & & & & \\
\hline \multirow{4}{*}{$\begin{array}{l}\text { Discharge } \\
\text { Difference }\end{array}$} & SR & $-75 \%$ & $-86 \%$ & $-87 \%$ \\
\hline & & & & \\
\hline & LR & $-75 \%$ & $-93 \%$ & $-93 \%$ \\
\hline & $\mathrm{DM}$ & $1 \%$ & $0 \%$ & $3 \%$ \\
\hline \multirow{3}{*}{$\begin{array}{l}\text { Average Time of } \\
\text { Peak Difference }\end{array}$} & SR & $2 \%$ & $3 \%$ & $6 \%$ \\
\hline & LR & $2 \%$ & $5 \%$ & $7 \%$ \\
\hline & $\mathrm{DM}$ & $0 \%$ & $3 \%$ & $-34 \%$ \\
\hline \multirow{2}{*}{$\begin{array}{c}\text { Average Total } \\
\text { Runoff Difference }\end{array}$} & SR & $-52 \%$ & $-62 \%$ & $-68 \%$ \\
\hline & LR & $-52 \%$ & $-74 \%$ & $-79 \%$ \\
\hline
\end{tabular}

Note: DM=during mining; SR = short-term reclaimed $(<5$ years $) ; \mathrm{LR}=$ long-term reclaimed $(>5$ years)

These results indicate that if the $\mathrm{CN}$ value of 84 were applicable to the original watershed the GLD would still be the most appropriate reclamation design choice. Caution should be taken when interpreting these results as these comparisons may not be an accurate portrayal of the effectiveness of the reclamation designs. The CN used to generate the peak discharge, time of peak, and total runoff volume for the original watershed was calculated for only two forested, undisturbed watersheds in central West Virginia and may not accurately predict the hydrologic response of an undisturbed watershed in southern West Virginia. 


\subsubsection{Comparison of GLD reclamation to conventional reclamation}

The during-mining peak discharge values of every reclamation design were much higher than the peak discharge values generated by the AOC design. The GLD generated peak discharge values as much as 3,240\% higher than the discharge values generated by the AOC design (Table 39). The retrofit and detention pond designs yielded similar results with peak discharge values 1,579\% and 2,721\% respectively higher at the 1-year return period (Table 39). The during-mining peak discharge values generated by the alternative reclamation designs more closely resembled the values generated by the AOC design as the rainfall return period increased. Post-mining peak discharge values were closer to the AOC peak discharge values for each reclamation design. The GLD generated peak discharge values larger than the AOC design for the 1-, 2-, and 5-year return period rainfall event, but at the 10-year and greater return period the GLD generated lower peak discharge values (Table 39). The retrofit and detention pond designs followed similar patterns for the short-term reclamation though they generated lower peak discharge values than the GLD reclamation design (Table 39). Long-term peak discharge values for the retrofit and detention pond design were lower than the AOC peak discharges for all return periods (Table 39).

The time of peak values for the GLD were all within 3\% of the values generated by the AOC design for all return periods (Table 40). The retrofit design generated time of peak values within 3\% for the during-mining conditions, time of peak values within $6 \%$ for the short-term reclamation, and within 8\% for the long-term reclamation conditions (Table 40). The detention pond design generated time of peak values within 4\% for during-mining conditions, within 3\% for short-term reclamation conditions, and within $4 \%$ for long-term reclamation conditions (Table 40). 
Table 39: Percent difference of peak discharge in comparison with the conventional reclamation

\begin{tabular}{|c|c|c|c|c|}
\hline $\begin{array}{c}\text { Return } \\
\text { period } \\
\text { (yrs) }\end{array}$ & $\begin{array}{c}\text { Time of } \\
\text { Reclamation }\end{array}$ & $\begin{array}{l}\text { GLD } \\
(\%)\end{array}$ & $\begin{array}{c}\text { Retrofit } \\
\text { (\%) }\end{array}$ & $\begin{array}{c}\text { Detention } \\
\text { (\%) }\end{array}$ \\
\hline \multirow{3}{*}{1} & $\mathrm{DM}$ & 3,240 & 1,579 & 2,721 \\
\hline & SR & 263 & 117 & 131 \\
\hline & LR & 263 & -46 & -42 \\
\hline \multirow{3}{*}{2} & $\mathrm{DM}$ & 2,274 & 1,094 & 1,879 \\
\hline & SR & 263 & 113 & 118 \\
\hline & LR & 263 & -34 & -31 \\
\hline \multirow{3}{*}{5} & $\mathrm{DM}$ & 810 & 357 & 646 \\
\hline & SR & 109 & 24 & 19 \\
\hline & LR & 109 & -48 & -48 \\
\hline \multirow{3}{*}{10} & $\mathrm{DM}$ & 220 & 61 & 158 \\
\hline & SR & -13 & -50 & -50 \\
\hline & LR & -13 & -74 & -75 \\
\hline \multirow{3}{*}{25} & $\mathrm{DM}$ & 119 & 10 & 74 \\
\hline & SR & -31 & -62 & -61 \\
\hline & LR & -31 & -78 & -78 \\
\hline \multirow{3}{*}{50} & DM & 103 & 2 & 59 \\
\hline & SR & -33 & -63 & -62 \\
\hline & LR & -33 & -78 & -78 \\
\hline \multirow{3}{*}{100} & $\mathrm{DM}$ & 89 & -5 & 48 \\
\hline & SR & -32 & -64 & -62 \\
\hline & LR & -32 & -78 & -77 \\
\hline \multirow{3}{*}{500} & $\mathrm{DM}$ & 98 & -12 & 34 \\
\hline & SR & -15 & -62 & -62 \\
\hline & LR & -15 & -75 & -75 \\
\hline
\end{tabular}


Table 40: Percent difference of time of peak in comparison with the conventional reclamation

\begin{tabular}{|c|c|c|c|c|}
\hline $\begin{array}{c}\text { Return } \\
\text { period } \\
(y r s)\end{array}$ & $\begin{array}{c}\text { Time of } \\
\text { Reclamation }\end{array}$ & $\begin{array}{l}\text { GLD } \\
(\%)\end{array}$ & $\begin{array}{c}\text { Retrofit } \\
\text { (\%) }\end{array}$ & $\begin{array}{c}\text { Detention } \\
\text { (\%) }\end{array}$ \\
\hline \multirow{3}{*}{1} & $\mathrm{DM}$ & -3 & -2 & -4 \\
\hline & SR & -1 & 3 & 0 \\
\hline & LR & -1 & 4 & 3 \\
\hline \multirow{3}{*}{2} & $\mathrm{DM}$ & -3 & -2 & -4 \\
\hline & SR & -2 & 1 & -1 \\
\hline & LR & -2 & 3 & 1 \\
\hline \multirow{3}{*}{5} & $\mathrm{DM}$ & -3 & -1 & -4 \\
\hline & SR & -1 & 2 & -1 \\
\hline & LR & -1 & 3 & 1 \\
\hline \multirow{3}{*}{10} & $\mathrm{DM}$ & 0 & 2 & -1 \\
\hline & SR & 2 & 5 & 2 \\
\hline & LR & 2 & 6 & 3 \\
\hline \multirow{3}{*}{25} & $\mathrm{DM}$ & 1 & 2 & 0 \\
\hline & SR & 2 & 6 & 3 \\
\hline & LR & 2 & 7 & 4 \\
\hline \multirow{3}{*}{50} & $\mathrm{DM}$ & 1 & 2 & 0 \\
\hline & SR & 2 & 6 & 3 \\
\hline & LR & 2 & 7 & 4 \\
\hline \multirow{3}{*}{100} & $\mathrm{DM}$ & 1 & 3 & 0 \\
\hline & SR & 2 & 6 & 3 \\
\hline & LR & 2 & 8 & 4 \\
\hline \multirow{3}{*}{500} & $\mathrm{DM}$ & 1 & 3 & 0 \\
\hline & SR & 1 & 6 & 3 \\
\hline & LR & 1 & 6 & 4 \\
\hline
\end{tabular}




\section{Conclusions}

The hydrologic responses of three alternative surface mining reclamation designs were modeled for a MTM in southern West Virginia. The hydrologic models were created using TR20 and TR-55 and were modeled for storm events ranging from 1- to 500-year events of Type-II distribution. The hydrologic response of each of the three designs was compared to the original, undisturbed watershed to evaluate the effectiveness of the alternative reclamation designs.

- The curve number (CN) calculated for the mined watersheds in southern WV were within the range of published values for the Central Appalachian region (e.g. (Hoomehr 2012, McCormick and Eshleman 2011, Ritter and Gardner 1991). The lack of published CNs for West Virginia mine sites resulted in the selection of $\mathrm{CN}$ values calculated for mining sites outside of the state. More research is needed to calculate CNs for MTM sites within West Virginia so that accurate CN values can be applied to MTM sites in West Virginia. This can be achieved through field monitoring of mined watersheds in southern West Virginia. Hourly streamflow and precipitation data would be required for CN calculations for watersheds impacted by MTM (McCormick et al. 2009). Land use documentation would provide mining and reclamation dates that would allow for the calculation of during-mining, short-term or long-term CNs.

- The hydrologic modeling results indicated that the hydrologic response from the first GLD alternative reclamation design most closely resembled the response of the original, undisturbed topography. Therefore GLD reclamation of watersheds affected by MTM in West Virginia can successfully generate surface water runoff conditions similar to the surrounding topography in Central Appalachia.

- The detention pond design lowered the peak discharge and total runoff volume below the values generated by the original, undisturbed topography. The storage within the detention ponds allows the potential to allow stream flow in excess of ephemeral conditions. However, the detention ponds need to be properly sized to allow greater storage of runoff if intermittent or perennial stream flow is desired which will require additional research.

- The effectiveness of the retrofit reclamation design was difficult to determine due to the changes in watershed area and drainage pattern. The alterations to the watershed resulted 
in reduced total runoff volume and peak discharge values in comparison to the original design, but these reductions can be attributed to the reduction in total watershed area.

\subsection{Study Limitations and Future Research}

Limitations of the study were attributed to the following:

- The selection of curve number values for reclaimed mine sites in southern West Virginia was made difficult by the lack of calculated CNs for MTM sites in WV. Appropriate curve number selection is crucial to generating accurate hydrologic models. Future research focused upon calculating CN values for reclaimed mine sites in West Virginia would allow for more accurate models and more effective reclamation designs.

- Research pertaining to the size and placement of detention ponds within the reclaimed watershed may allow for more effective intermittent stream generation within the watershed.

- Research investigating the watershed properties of undisturbed watersheds in the southern WV area would allow for the design of more accurate GLD reclamation sites. 


\section{References}

Bedient, Philip B., Huber, Wayne C., Vieux, Baxter E. (2013). "Hydrology and Floodplain Analysis.”Hydrologic Principles, Pearson Education, Inc., Upper Saddle River, NJ.

Bonta JV, Amerman CR, Harlukowicz TJ, Dick WA. (1997). "Impact of coal surface mining on three Ohio watersheds-Surface water hydrology.” JAWRA 33(4), 907-917.

Bugosh N. (2009). "A summary of some land surface and water quality monitoring results for constructed GeoFluv landforms.” Revitalizing the Environment: Proven Solutions and Innovative Approaches, National Meeting of the American Society of Mining and Reclamation, Billings, MT, May 3-June 5, 153-175.

Cronshey, R., McCuen, R.H., Miller, N., Rawls, W., Robbins, S., and Woodward, D. (1986). "Urban Hydrology for Small Watersheds TR-55." United States Department of Agriculture, Natural Resources Conservation Service, Conservation Engineering Division.

Decota Consutling Company, Inc. (2009). "Surface Water Runoff Analysis (SWORA)." Executive SUMMARY, Coal-Mac, Inc.

EPA. (2013). “Mid-Atlantic Mountaintop Mining.” U.S. Environmental Protection Agency. $<$ http://www.epa.gov/region3/mtntop/> (Oct. 4, 2013).

EPA. (2011). "The effects of mountaintop mines and valley fills on aquatic ecosystems of the central Appalachian coalfield.” Tech. Rep. EPA/600/R-09/138F. US Environmental Protection Agency.

Fang, Xing; Thompson, D.B.; Cleveland, T.G.; Pradhan, P.; Malla, R. (2008). “Time of Concentration Estimated Using Watershed Parameters Determined by Automated and Manual Methods.” Journal of Irrigation and Drainage Engineering, 134(2), 202-211.

Federal Emergency Management Agency _FEMA_._2004_. "Recommendations for using future conditions hydrology for the National Flood Insurance Program.” Final Rep., _http://www.fema.gov/fhm/ft-hydro.shtm_, Washington, D.C.

Fennessey, L.A.J., and Hawkins, R.H. (2001). “The NRCS Curve Number, a New Look at an Old Tool.” Pennsylvania Stormwater Management Symposium Villanova, PA.

Ferrari, J.R.; Lookingbill, T.R.; McCormick, B.C.; Townsend, P.A.; Eshleman, K.N. (2009). "Surface mining and reclamation effects on flood response of watersheds in the central Appalachian Plateau region.” Water Resources Research. 45.

Fritz K.M., Fulton S., Johnson B.R., Barton C.D., Jack J.D., Word D.A., Burke, R.A. 2010. "Structural and functional characteristics of natural and constructed channels draining a reclaimed mountaintop removal and valley fill coal mine." The North American Benthological Society, 29(2), 673-689. 
Hawkins, R. H. (1993). “Asymptotic determination of runoff curve numbers from data.” J. Irrig. and Drain. Div., 119(2), 334-345.

Hawkins, R.H., Woodward, D.E., and Jiang, R. (2002). "Runoff curve number method: Examination of the initial abstraction ratio.” Proc., Second Federal Interagency Hydrologic Modeling Conference, USGS, Las Vegas, NV., 40-51.

Hoomehr, S., Schwartz, J., Yoder, D., Drumm, E., and Wright, W. (2012). "Curve Numbers for Low-Compaction Steep-Sloped Reclaimed Mine Lands in the Southern Appalachians." J. Hydrol. Eng., 10.1061/(ASCE)HE.1943-5584.0000746 (Nov. 12, 2012).

Kirpich, Z.P. (1940). “Time of concentration of small agricultural watersheds.” Civil Engineering, 10(6), 362.

Maidment, D.R. (1992). “Handbook of Hydrology.” Flood Runoff, McGraw-Hill Professional, New York City, NY.

Martin-Duque JF, Sanz MA, Bodoque JM, Lucia A, Martin-Moreno C. (2009). "Restoring earth surface processes through landform design. A 13-year monitoring of a geomorphic reclamation model for quarries on slopes.” Earth Surface Processes and Landforms, 35, 531-548.

Martin-Moreno C, Martin-Duque JF, Nicolau JM, Sanchez L, Ruiz R, Sanz MA, Lucia A, Zapico I. (2008). “A geomorphic approach for the ecological restoration of kaolin mines at the Upper Tagus Natural Park (Spain).” $6^{\text {th }}$ European Conference on Ecological Restoration, Ghent, Belgium, August 8-12.

McCormick, B.C., and Eshleman, K.N. (2011). “Assessing hydrologic change in surface-mined watersheds using the curve number method.” Journal of Hydrological Engineering, 16(7), 575-584.

McCormick, B.C., Eshleman, K.N., Griffith, J.L., Townsend, P.A. (2009). “Detection of flooding responses at the river basin scale enhanced by land use change.” Water Resources Research, 45(8), W08401.

McCutcheon, S.C. (2003). "Hydrologic Evaluation of the Curve Number Method for Forest Management in West Virginia.” West Virginia Division of Forestry, Charleston, West Virginia.

McGarvey, Daniel J., Johnston, John M. 2012. “'Fishing’ for Alternatives to Mountaintop Mining in Southern West Virginia.” AMBIO, 42, 298-308.

Measles D, Bugosh N. 2007. "Making and building a fluvial geomorphic reclamation design at an active dragline mine using the GeoFluv ${ }^{\mathrm{TM}}$ design method.” 30 Years of SMCRA and Beyond, National Meeting of the American Society of Mining and Reclamation, Gillette, WY, June 2-7, 2007, 449-456. 
Merkel, W.H. (2002). "Muskingum-Cunge Flood Routing Procedures in NRCS Hydrologic Models.” Second Federal Interagency Hydrologic Modeling Conference, July 2002.

Michael, Peter R.; Superfesky, Michael J.; Uranowski, Louis J. (2010). “Challenges to Applying Geomorphic and Stream Reclamation Methodologies to Mountaintop Mining and Excess Spoil Fill Construction in Steep-Slope Topography (E.G. Central Appalachia).” Bridging Reclamation, Science and Community, National Meeting of the American Society of Mining and Reclamation, Lexington, KY, June 5-11, 2010, 610-634.

Mockus, V., (1965). “Design Hydrograph.” National Engineering Handbook, McKeever, V., Owen, W., and Rallison, R., eds.

National Oceanic and Atmospheric Administration (2013). "Index of /precip/p_download_new." Advanced Hydrologic Prediction Service, $<$ http://water.weather.gov/precip/p_download_new/> (Jun. 21, 2013).

Natural Resource Conservation Service (NRCS). (1972). "Hydrology.” National Engineering Handbook, Sec 4. U.S. Department of Agriculture, Washington, D.C.

Natural Resources Conservation Service (NRCS). (1986). "Urban Hydrology for Small Watersheds.” Technical Release-55, U.S. Department of Agriculture, Washington, DC.

Negley, T.L.; Eshleman, K.N. (2006). "Comparison of stormflow responses of surface-mined and forested watersheds in the Appalachian Mountains, USA.” Hydrological Processes. 20 (16), 3467-3483.

Negussie H. Tedela, Steven C. McCutcheon, P.E., M.ASCE, John L. Campbell; Wayne T. Swank, Mary Beth Adams, and Todd C. Rasmussen. (2012). "Curve Numbers for Nine Mountainous Eastern United States Watersheds: Sesonal Variation and Forest Cutting.” J. Hydrol. Eng. 17, 1199-1203.

Negussie H. Tedela, Steven C. McCutcheon, P.E., M.ASCE, Todd C. Rasmussen, Richard H. Hawkins, P.E., F.ASCE, Wayne T. Swank, John L. Campbell, Mary Beth Adams, C. Rhett Jackson, and Ernest W. Tollner, P.E.. (2012). "Runoff Curve Numbers for 10 Small Forested Watersheds in the Mountains of the Eastern United States”. J. Hydrol. Eng., 17, 1188-1198.

Office of Surface Mining Reclamation and Enforcement (OSMRE), Albuquerque Area Office (2009). “Topic-Specific Evaluation Report.” Albuquerque, NM, 9-10.

Palmer, M.A., Bernhardt, E.S., Schlesinger, W.H., Eshleman, K.N., Foufoula-Georgiou, E., Hendryx, M.S., Lemly, A.D., Likens, G.E., Loucks, O.L., Power, M.E., White, P.S. \& Wilcock, P.R. (2010). “Mountaintop mining consequences.” Science. 327, 148-149.

Phillips, J.D., (2003). "Impacts of surface mine valley fills on headwater floods in eastern Kentucky.” Environmental Geology 45, 367-380 
Ponce, V. and Hawkins, R. (1996). "Runoff Curve Number: Has It Reached Maturity?.” J. Hydrol. Eng., 1(1), 11-19.

Ritter, J. and Gardner, T. (1991). "Runoff Curve Numbers for Reclaimed Surface Mines in Pennsylvania.” J. Irrig. Drain Eng., 117(5), 656-666.

Sears, A., C. Bise, J. Quaranta, and L. Hopkinson. (2013). "Methodology for geomorphic landform design of valley-fills in Appalachia surface mine reclamation.” In Environmental Considerations in Energy Production, J.R. Craynon, ed. Society for Mining, Metallurgy, and Exploration (SME), Englewood, CO, 397-404.

Sears, A.E. (2012). "The Integration of Geomorphic Design into West Virginia Surface Mine Reclamation.” M.S. thesis, West Virginia Univ., Morgantown, W.V.

Shank, Michael (2010-11). “TAGIS Mapping Apps.” DEP Technical Applications \& GIS Unit. $<$ http://tagis.dep.wv.gov/mining/> (Feb. 19, 2013).

Taylor, T.J., Agouridis, C. T., Warner, R. C., and Barton, C. D. (2008). "Runoff curve numbers for loose-dumped spoil in the Cumberland Plateau of eastern Kentucky.” International Journal of Mining, eclamation and Environment, 23(2), 103-120

U.S. Department of Agriculture (2013). "Web Soil Survey.” Web Soil Survey, < http://websoilsurvey.nrcs.usda.gov/app/WebSoilSurvey.aspx> (Jun. 21, 2013).

U.S. Department of Agriculture ( 2009). Small Watershed Hydrology, WinTR-55 User Guide. U.S. Department of Agriculture. ftp://ftp.wcc.nrcs.usda.gov/wntsc/H\&H/WinTR55/WinTR55UserGuide.pdf

U.S. Department of Agriculture (2004). WinTR-20 User Guide. U.S. Department of Agriculture http://www.deldot.gov/information/business/drc/pd_files/plan_development/win_tr20_us er_guide.pdf

U.S. Geological Survey (2013). "Map of real-time streamflow compared to historical streamflow for the day of the year (West Virginia)." Water Watch, $<$ http://waterwatch.usgs.gov/?m=real\&r=wv> (Jun. 21, 2013).

U.S. Geological Survey (2013). “ArcGIS Explorer Online.” ArcGIS Explorer Online, $<$ http://www.arcgis.com/explorer/?services=4b53dfcd2e124f96a26c40bdeb738093> (Sept. 14, 2013).

U.S. Soil Conservation Service. (1985). National Engineering Handbook, Section 4, Hydrology. U.S. Government Print. Office, Washington, DC.

Warner, Richard C., Agouridis, Carmen T., Vingralek, Page T., Fogle, Alex W., (2010). "Reclaimed Mineland Curve Number Response to Temporal Distribution of Rainfall." JAWRA 46(4), 724-732

Walker, S.E., K. Banasik, W.J. Northcott, N. Jiang, Y. Yuan, and J.K. Mitchell. 1998. "Application of the SCS Curve Number Method to Mildly-Sloped Watersheds." 
American Society of Agricultural Engineers Annual International Meeting, American Society of Agricultural Engineers, St. Joseph, MI

West Virginia Department of Environmental Protection, Division of Mining and Reclamation. (1999). Permit Handbook: AOC and excess spoil disposal.

Woodward, D.E.; Hawkins, R.H.; Jian, R.; Hjelmfelt, A.T.; Van Mullem, J.A.; Quan, Q.D. (2003). "Runoff Curve Number Method: Examination of the Initial Abstraction Ratio." World Water \& Environmental Resources Congress 2003, Philadelphia, PA, June 23-26, $1-10$. 


\section{Appendix}

\section{Appendix A: Storm Response Hydrographs}

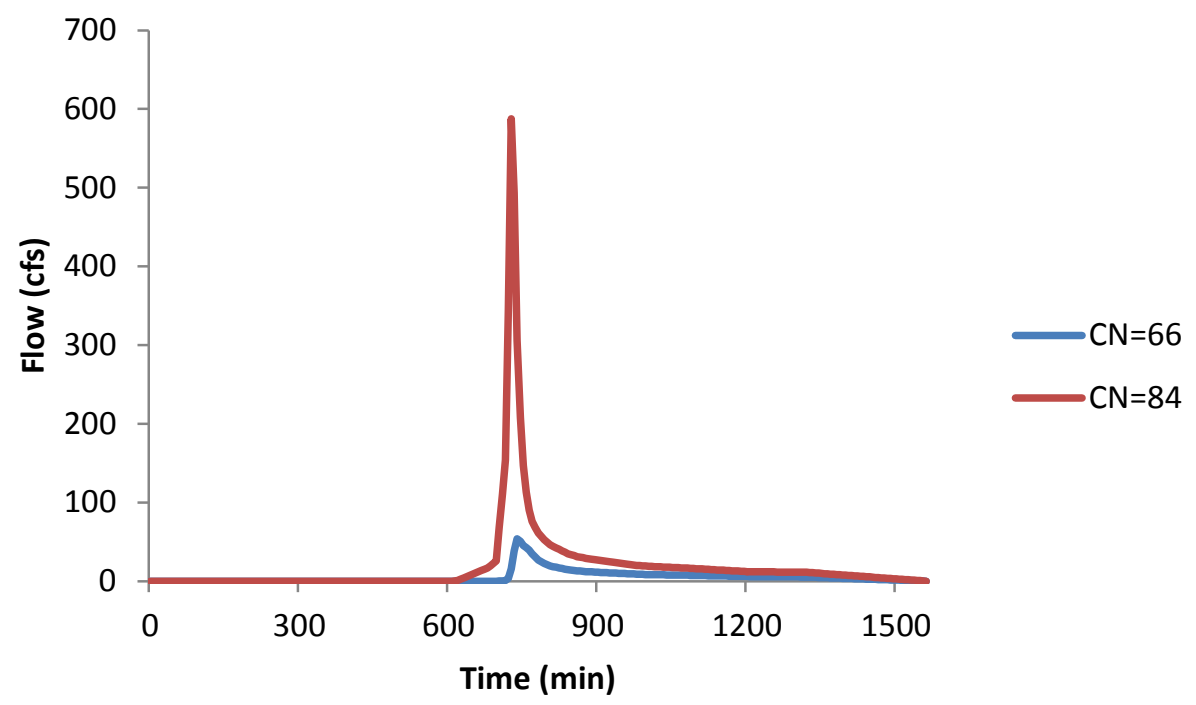

Figure 17: Storm response hydrograph for a 1-year storm at outlet $1 \mathrm{C}$ of original topography for varying $\mathrm{CN}$

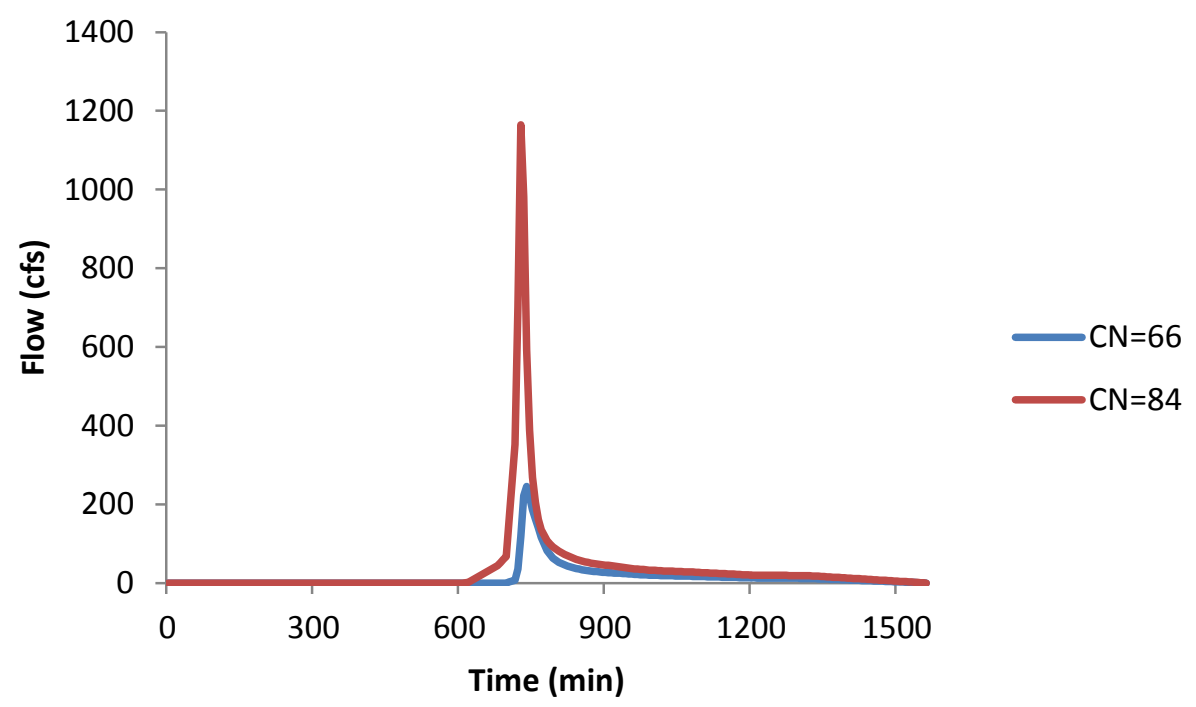

Figure 18: Storm response hydrograph for a 5-year storm at outlet $1 \mathrm{C}$ of original topography for varying $\mathrm{CN}$ 


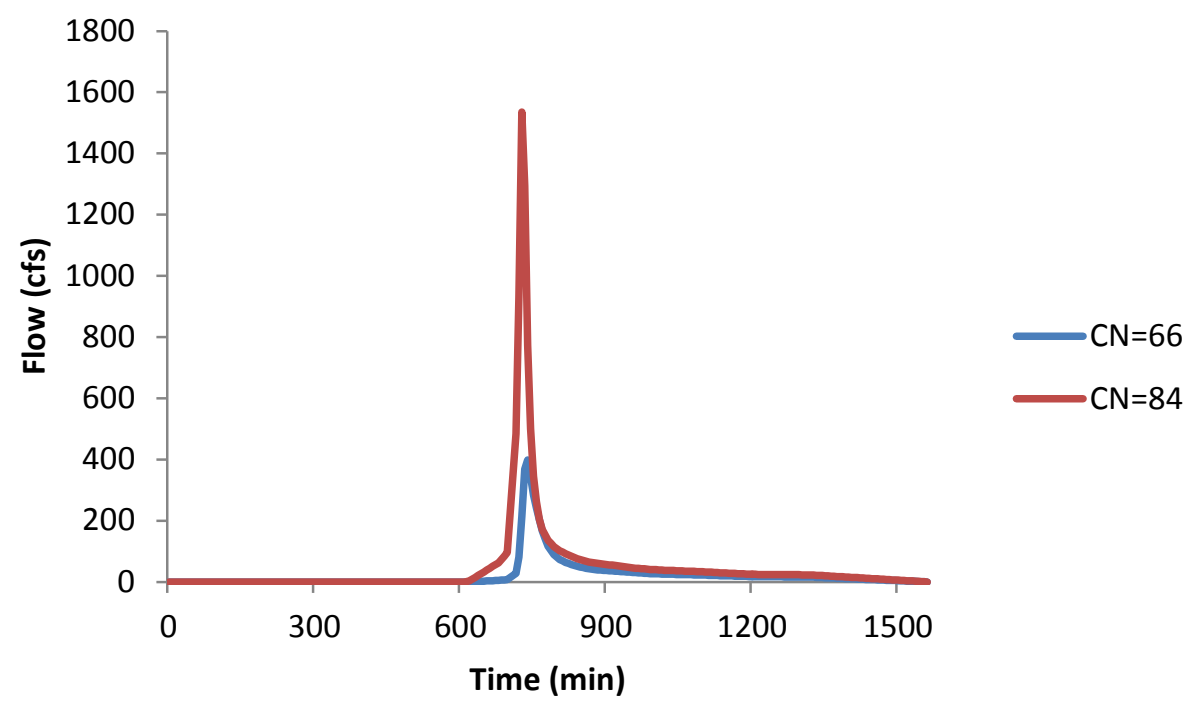

Figure 19: Storm response hydrograph for a 10-year storm at outlet $1 \mathrm{C}$ of original topography for varying $\mathrm{CN}$

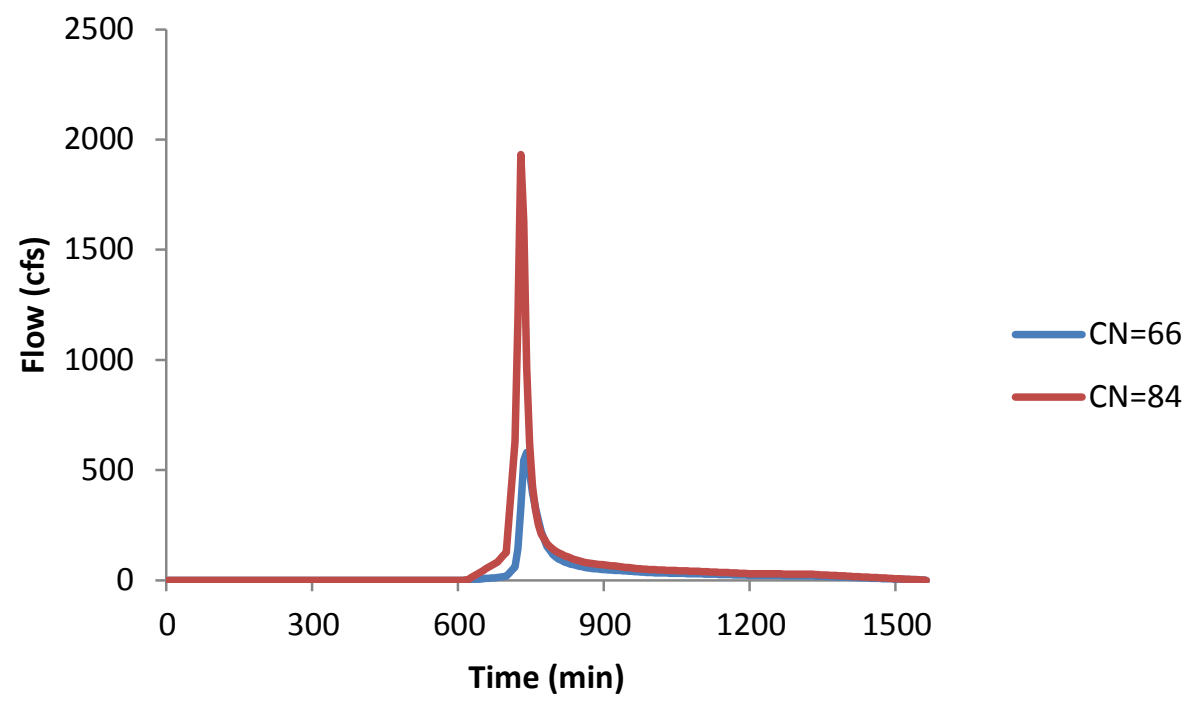

Figure 20: Storm response hydrograph for a 25-year storm at outlet $1 \mathrm{C}$ of original topography for varying $\mathrm{CN}$ 


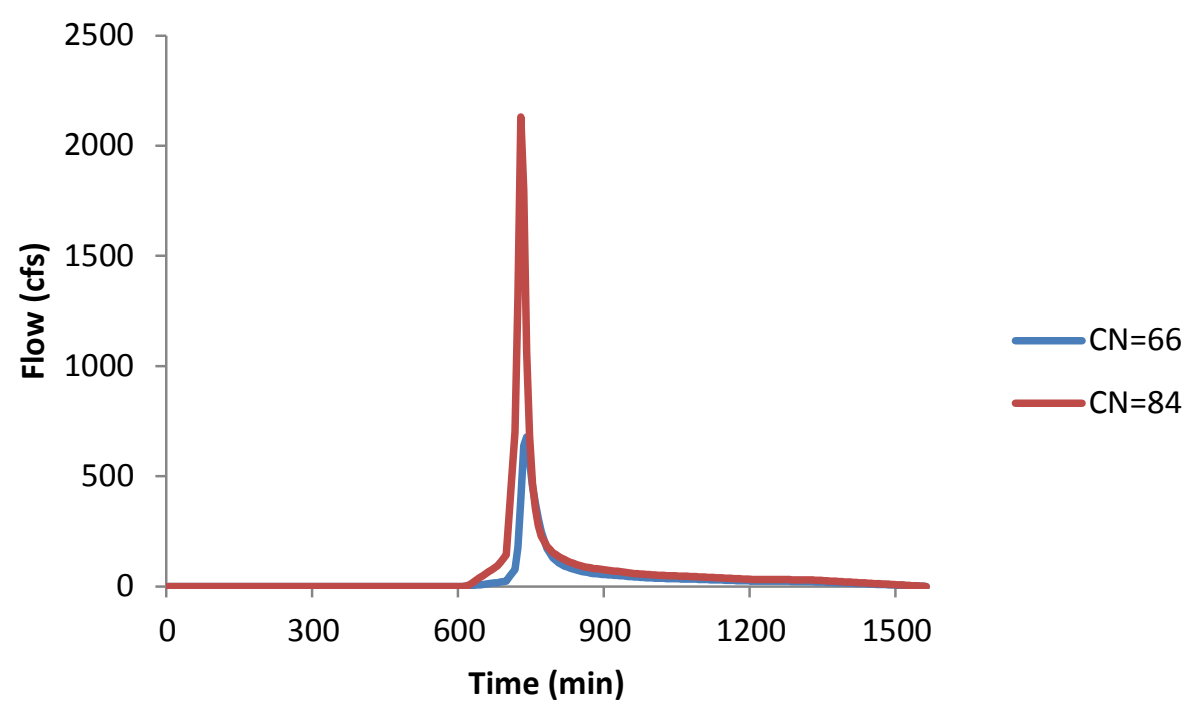

Figure 21: Storm response hydrograph for a 50-year storm at outlet $1 \mathrm{C}$ of original topography for varying $\mathrm{CN}$

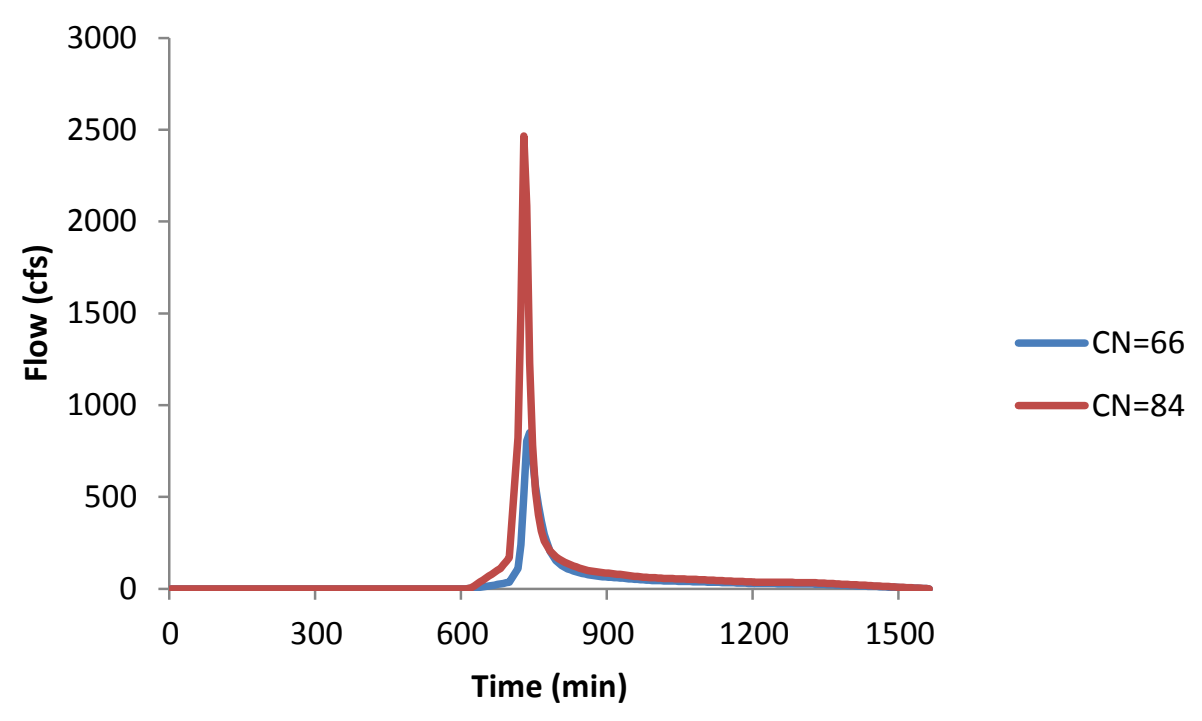

Figure 22: Storm response hydrograph for a 100-year storm at outlet $1 \mathrm{C}$ of original topography for varying $\mathrm{CN}$ 


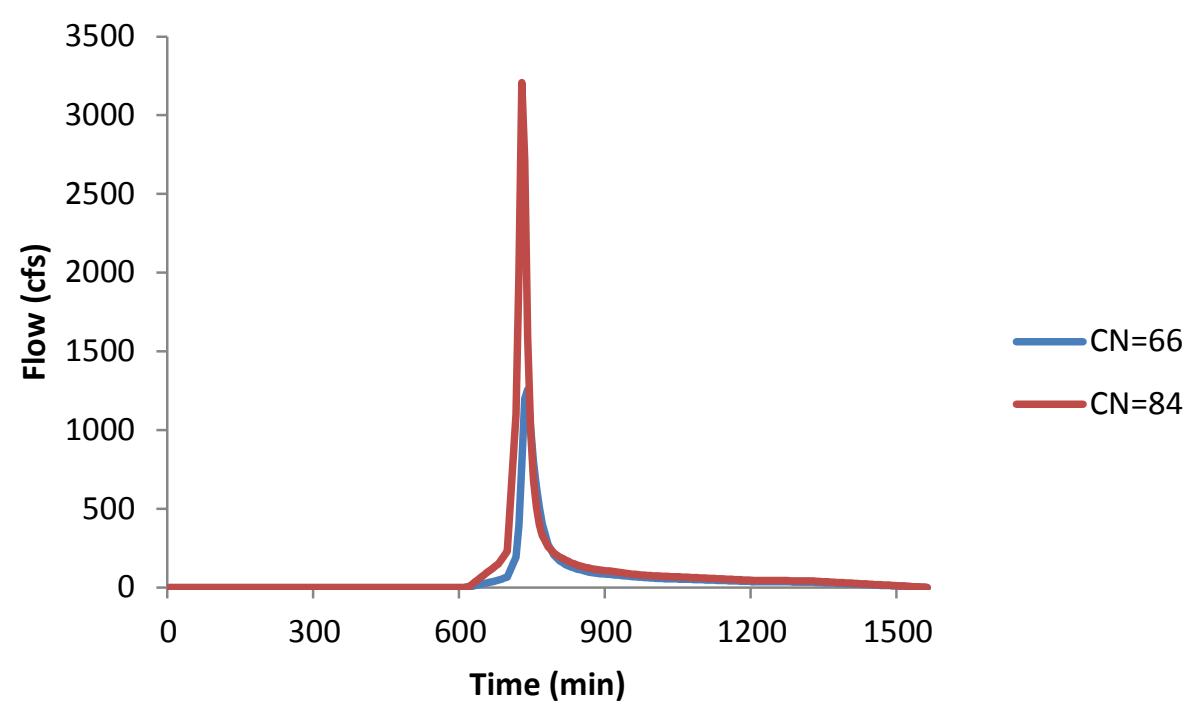

Figure 23: Storm response hydrograph for a 500-year storm at outlet $1 \mathrm{C}$ of original topography for varying $\mathrm{CN}$

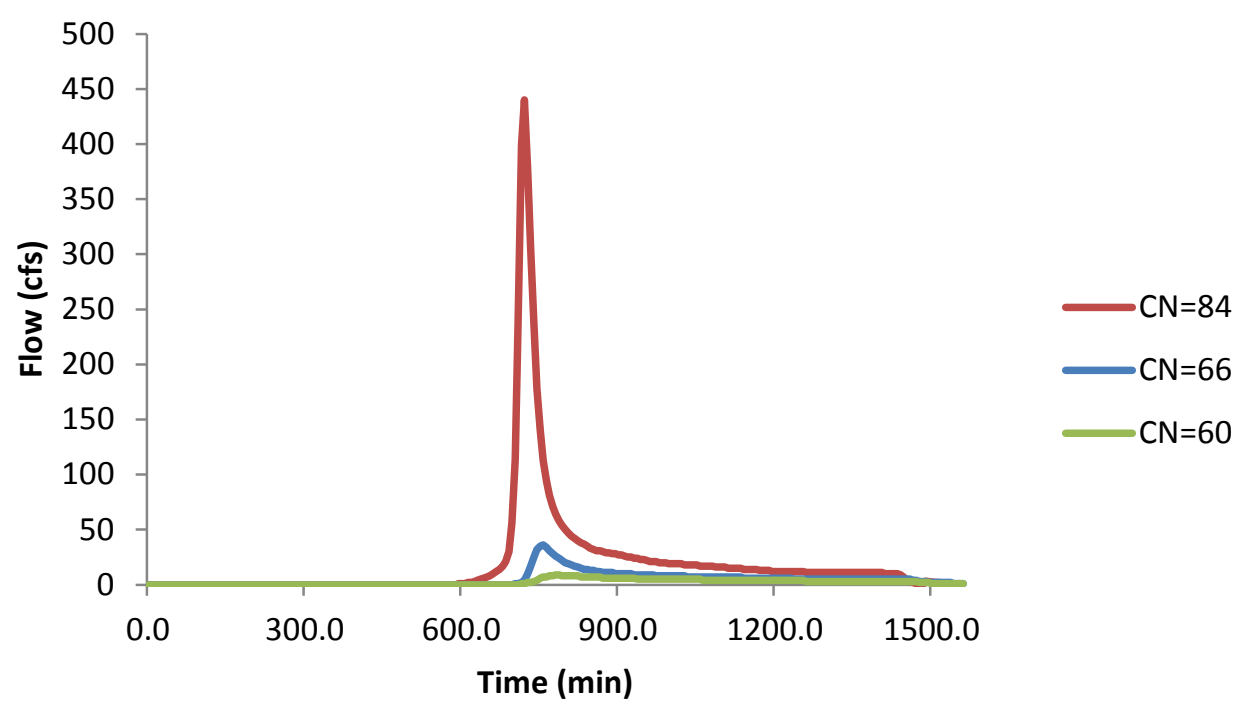

Figure 24: Storm response hydrograph for a 1-year storm at outlet $1 \mathrm{C}$ of detention pond design for varying $\mathrm{CN}$ 


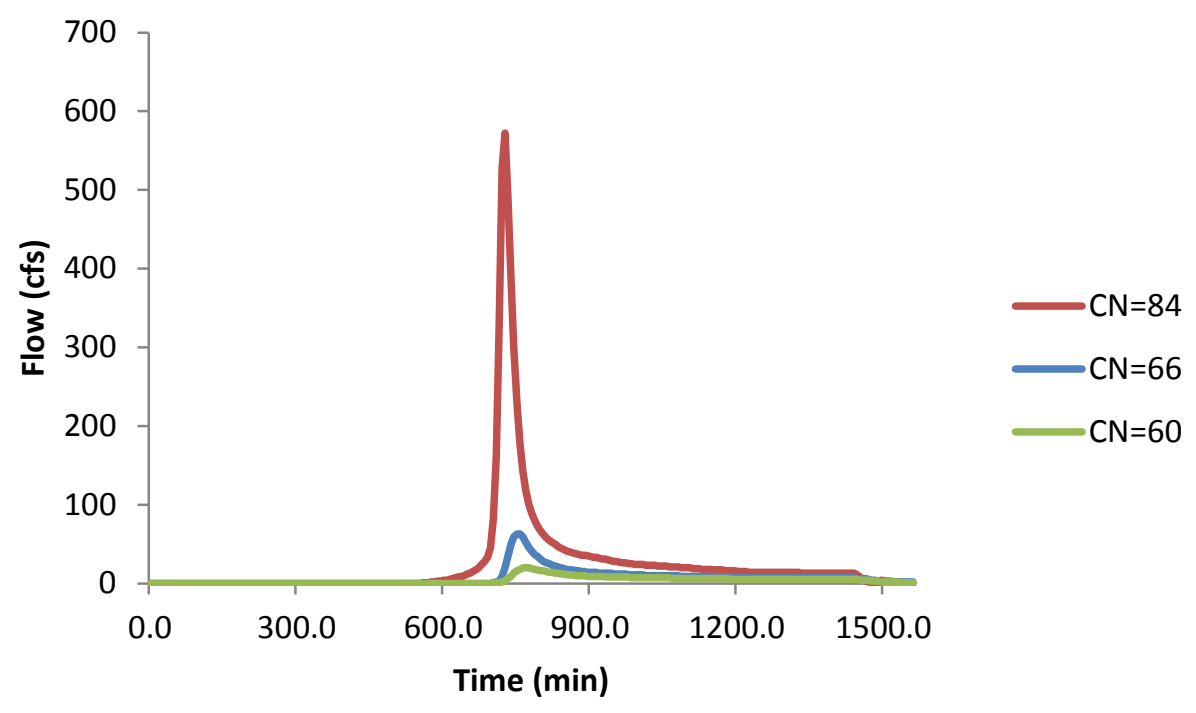

Figure 25: Storm response hydrograph for a 2-year storm at outlet $1 \mathrm{C}$ of detention pond design for varying $\mathrm{CN}$

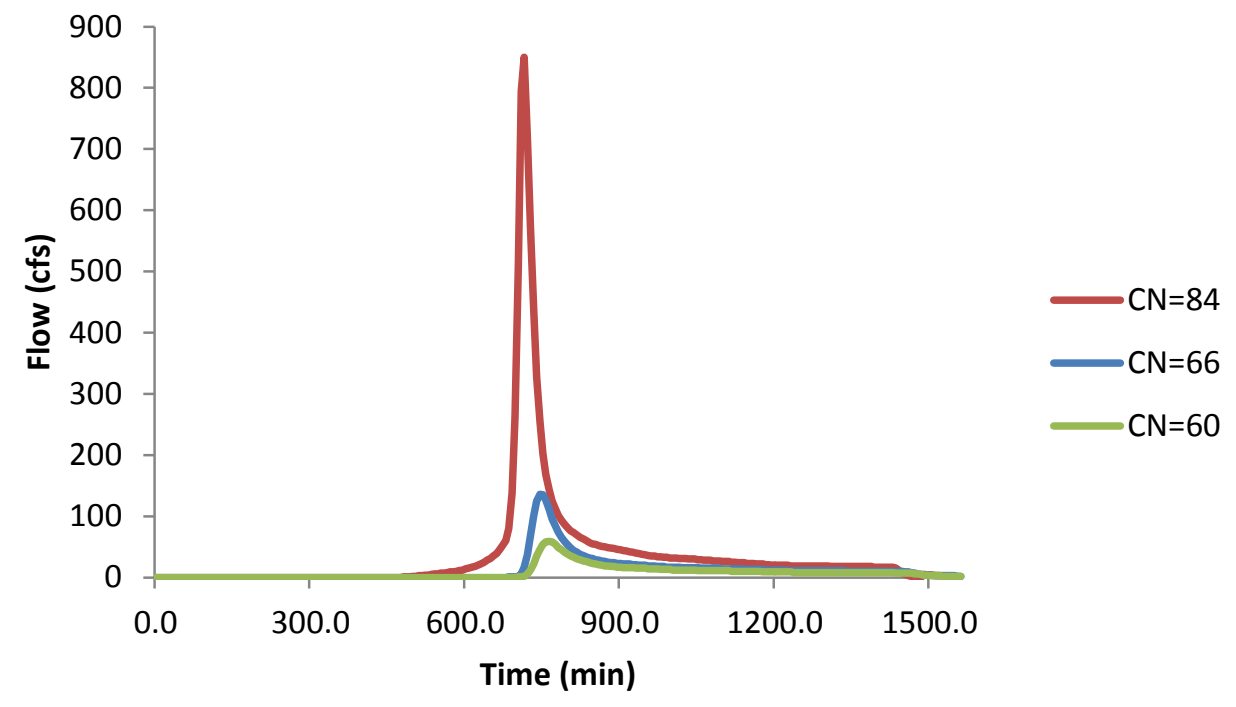

Figure 26: Storm response hydrograph for a 5-year storm at outlet $1 \mathrm{C}$ of detention pond design for varying $\mathrm{CN}$ 


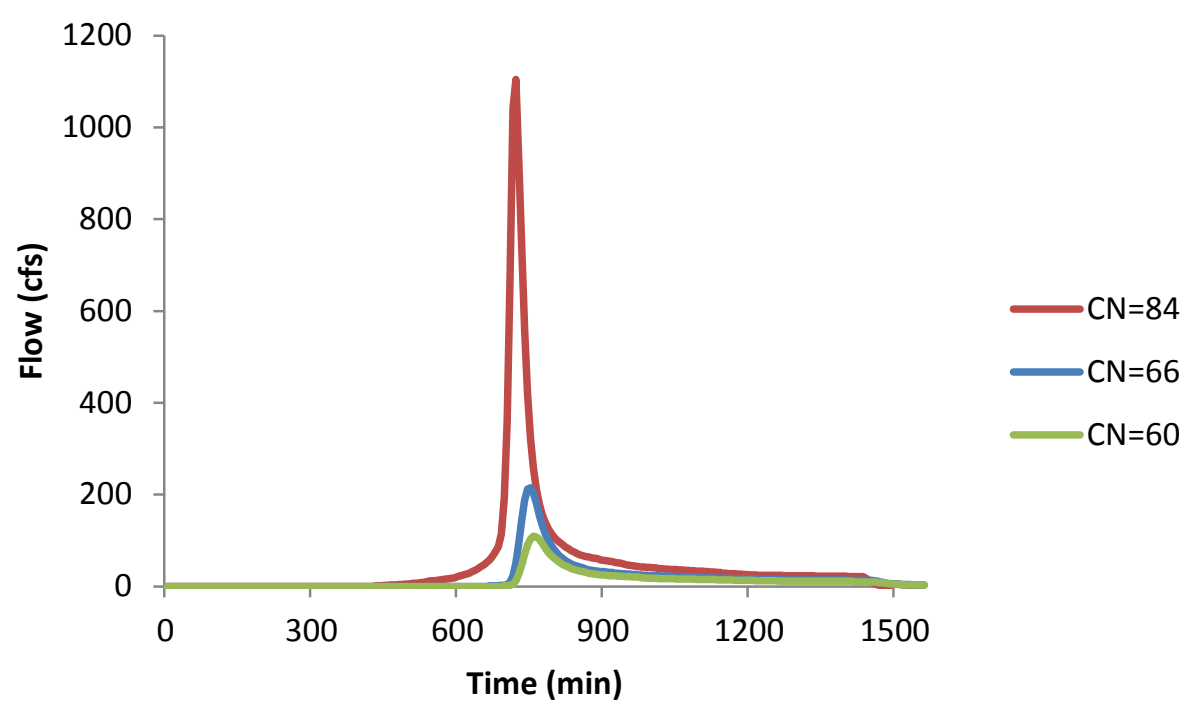

Figure 27: Storm response hydrograph for a 10-year storm at outlet 1C of detention pond design for varying $\mathrm{CN}$

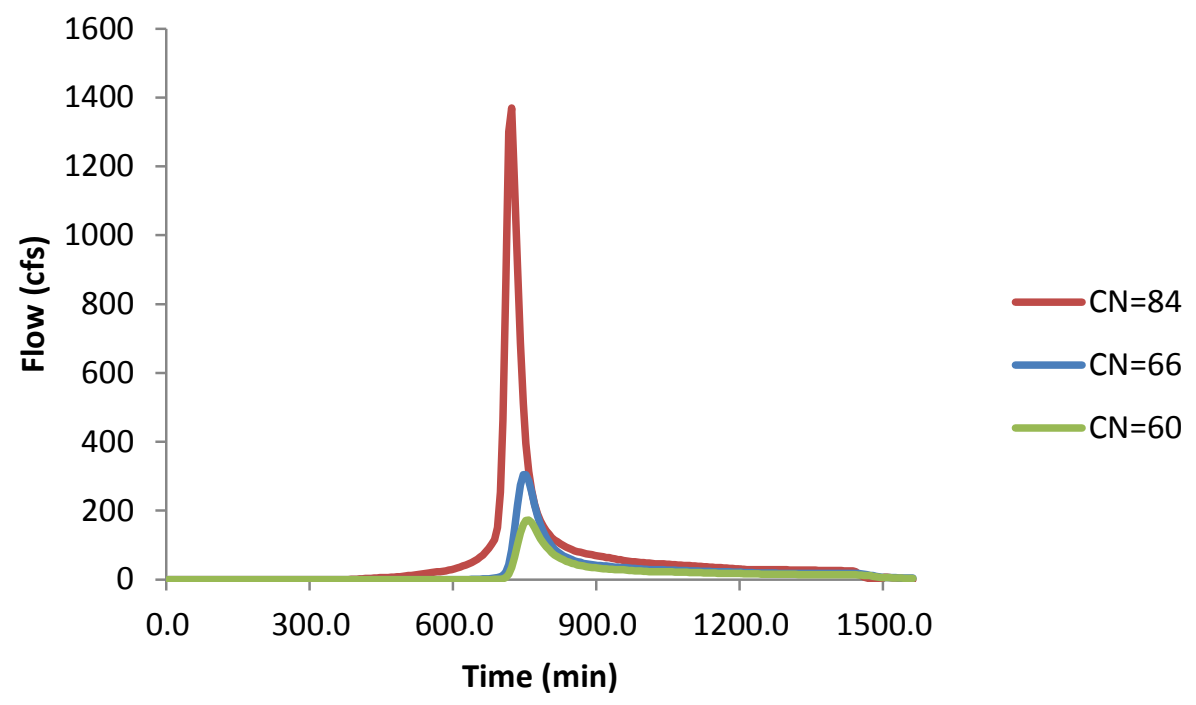

Figure 28: Storm response hydrograph for a 25-year storm at outlet 1C of detention pond design for varying $\mathrm{CN}$ 


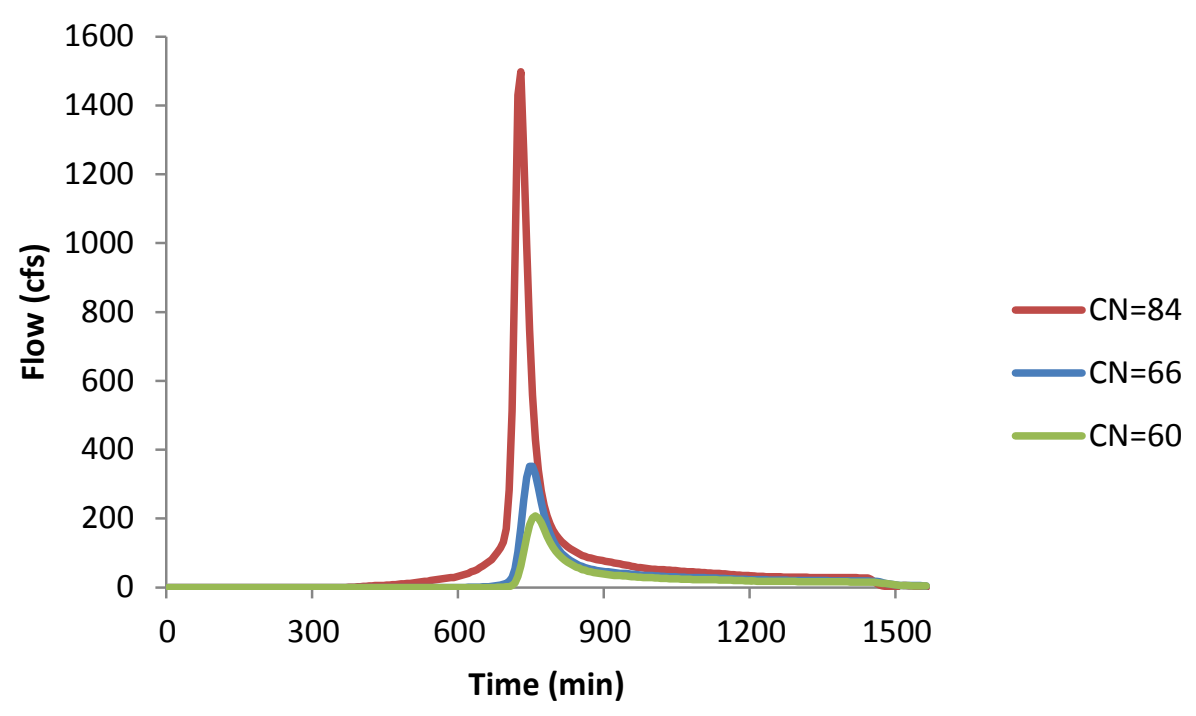

Figure 29: Storm response hydrograph for a 50-year storm at outlet $1 \mathrm{C}$ of detention pond design for varying $\mathrm{CN}$

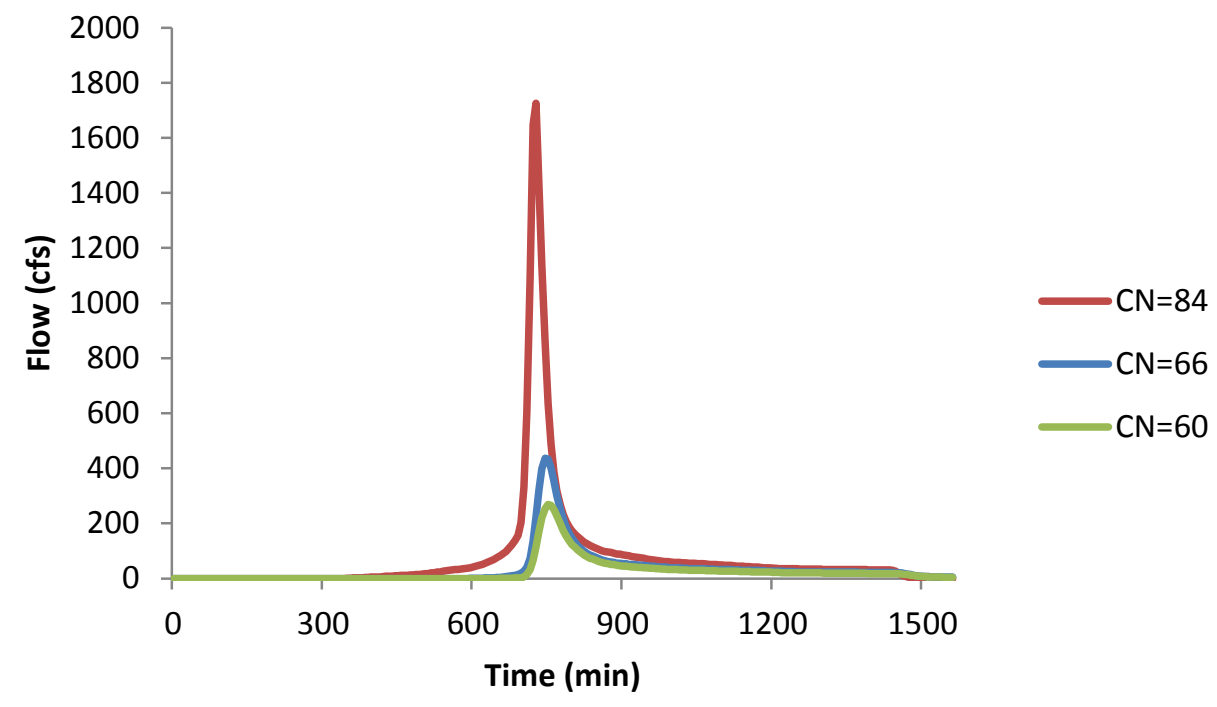

Figure 30: Storm response hydrograph for a 100-year storm at outlet $1 \mathrm{C}$ of detention pond design for varying $\mathrm{CN}$ 


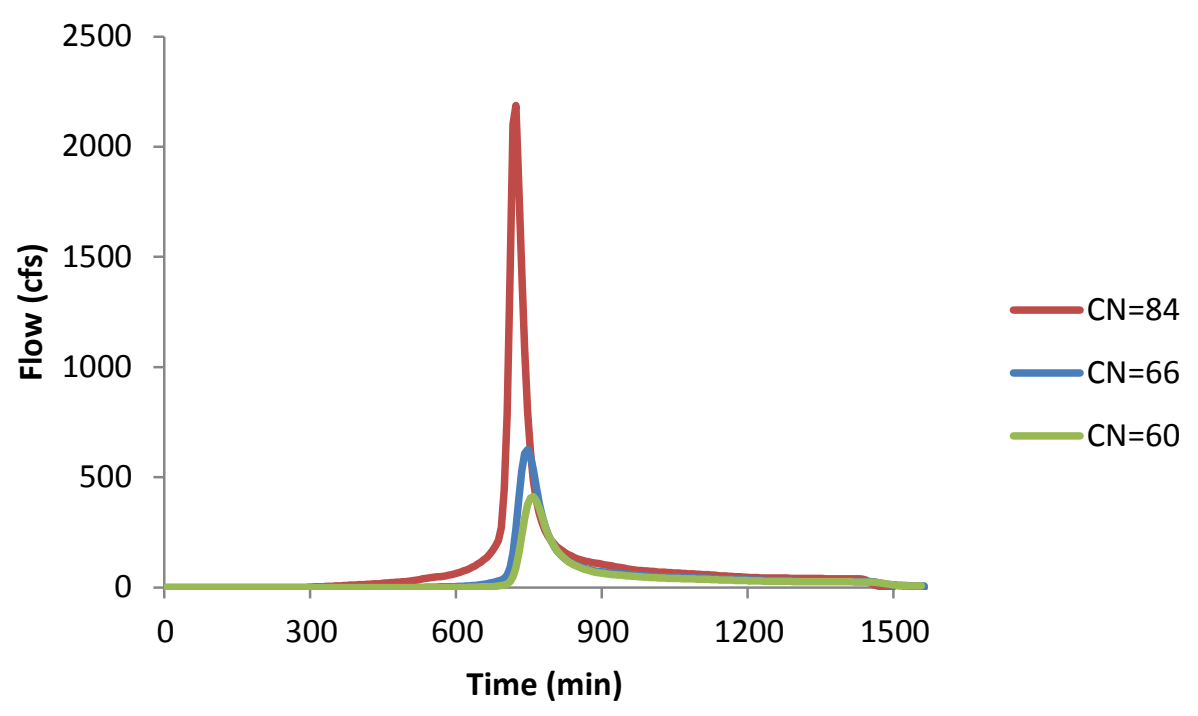

Figure 31: Storm response hydrograph for a 500-year storm at outlet 1C of detention pond design for varying $\mathrm{CN}$

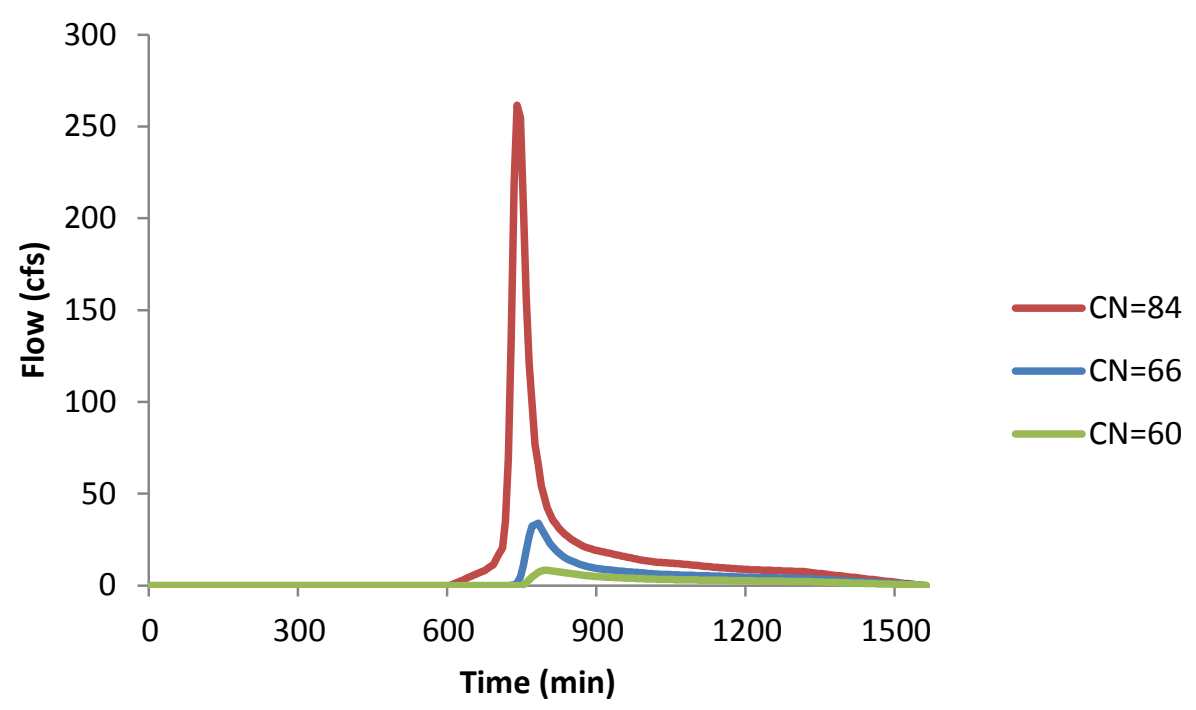

Figure 32: Storm response hydrograph for a 1-year storm at outlet $1 \mathrm{C}$ of retrofit design for varying $\mathbf{C N}$ 


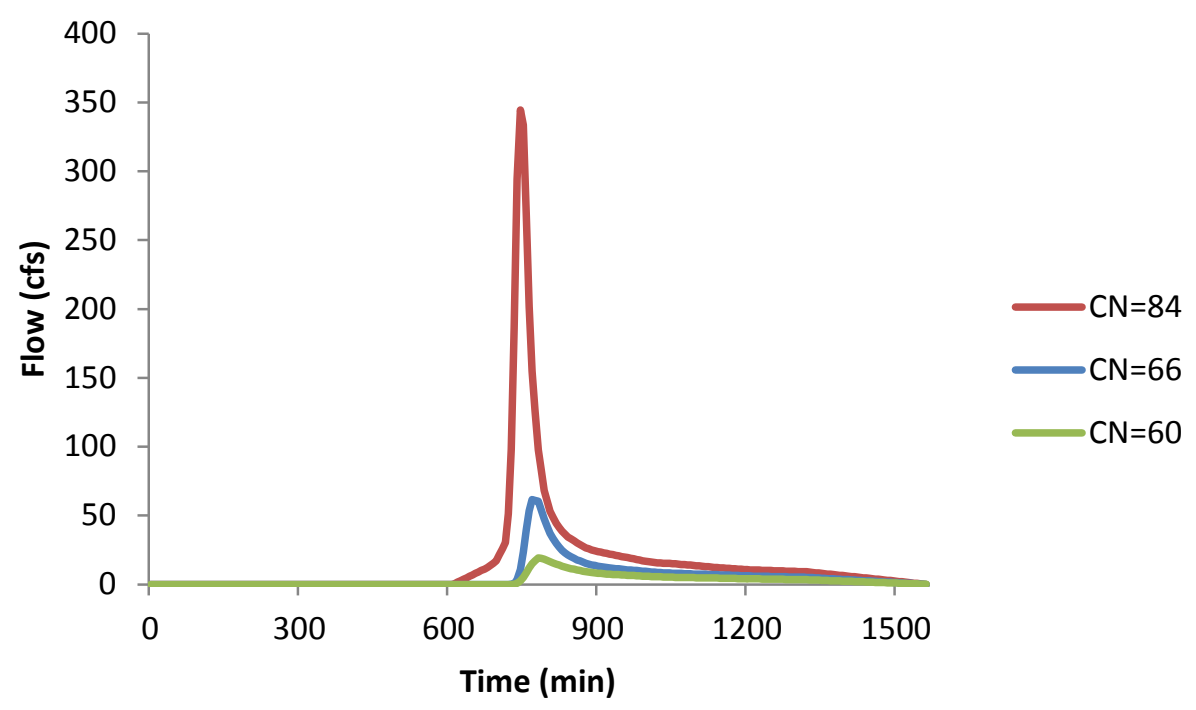

Figure 33: Storm response hydrograph for a 2-year storm at outlet $1 \mathrm{C}$ of retrofit design for varying $\mathbf{C N}$

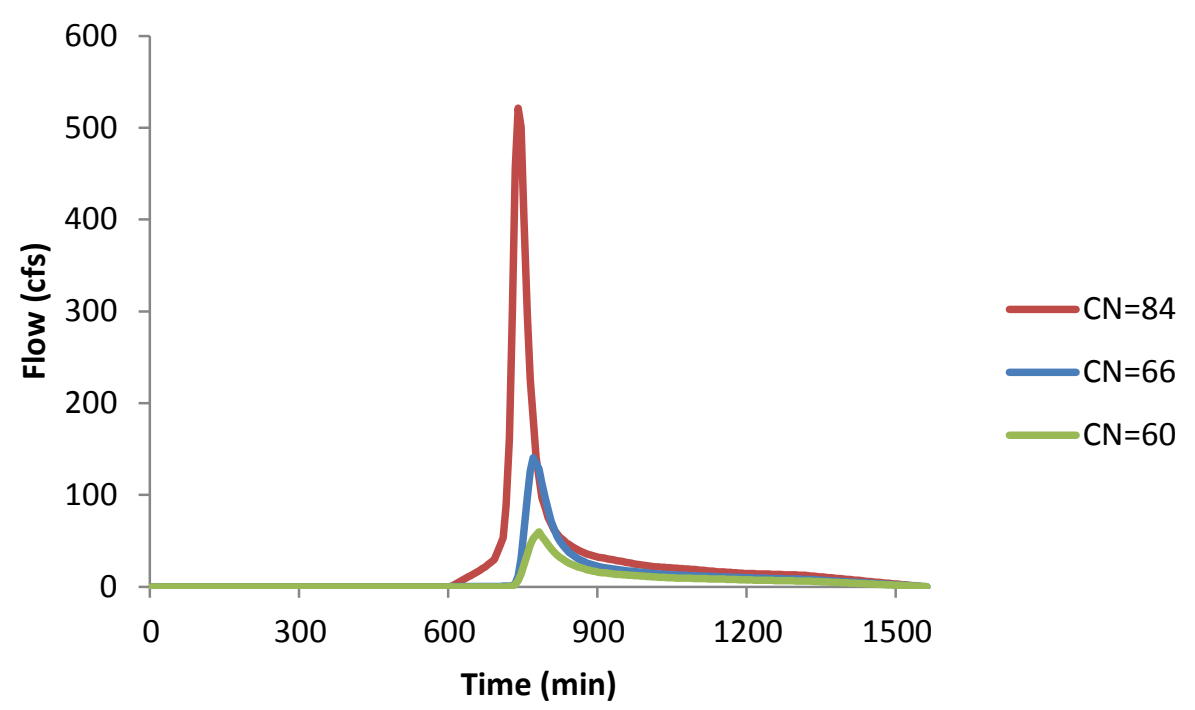

Figure 34: Storm response hydrograph for a 5-year storm at outlet $1 \mathrm{C}$ of retrofit design for varying $\mathbf{C N}$ 


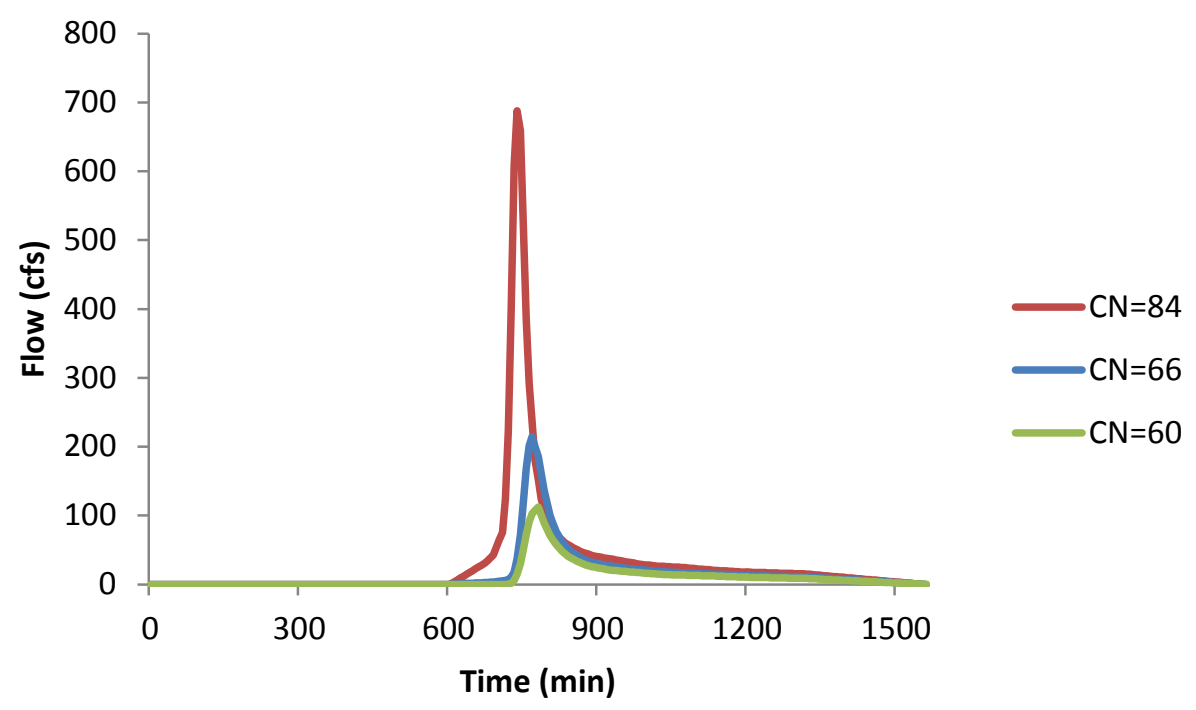

Figure 35: Storm response hydrograph for a 10-year storm at outlet 1C of retrofit design for varying $\mathrm{CN}$

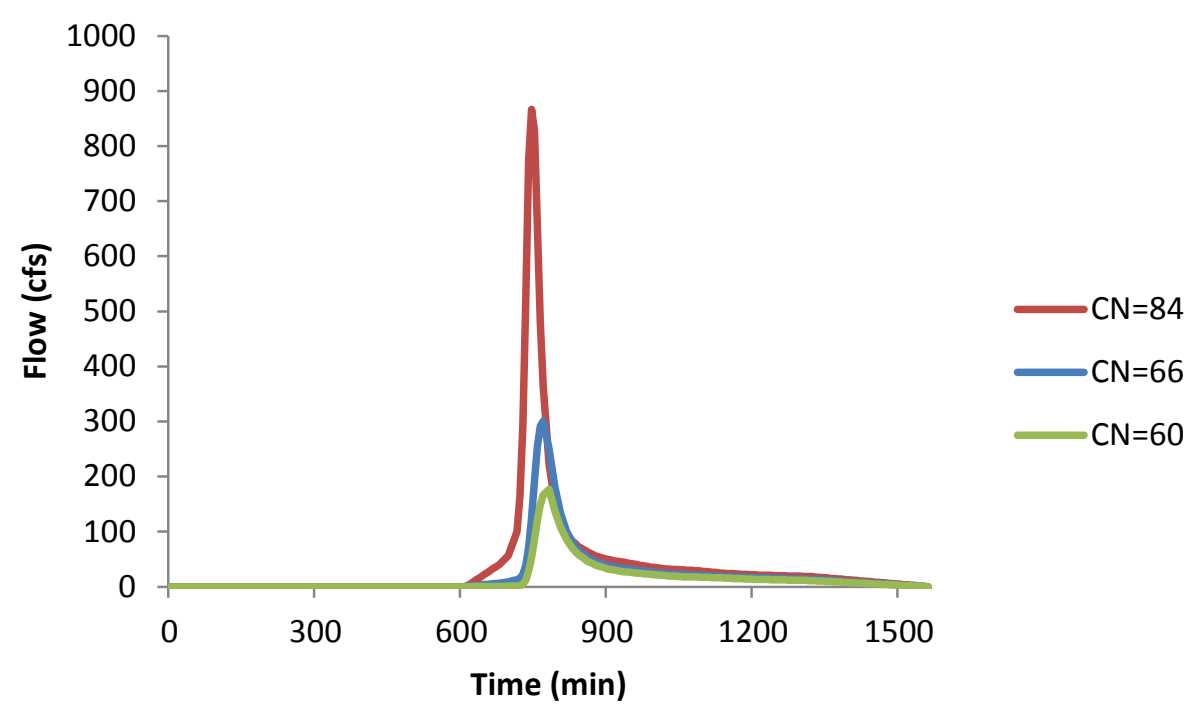

Figure 36: Storm response hydrograph for a 25-year storm at outlet 1C of retrofit design for varying $\mathrm{CN}$ 


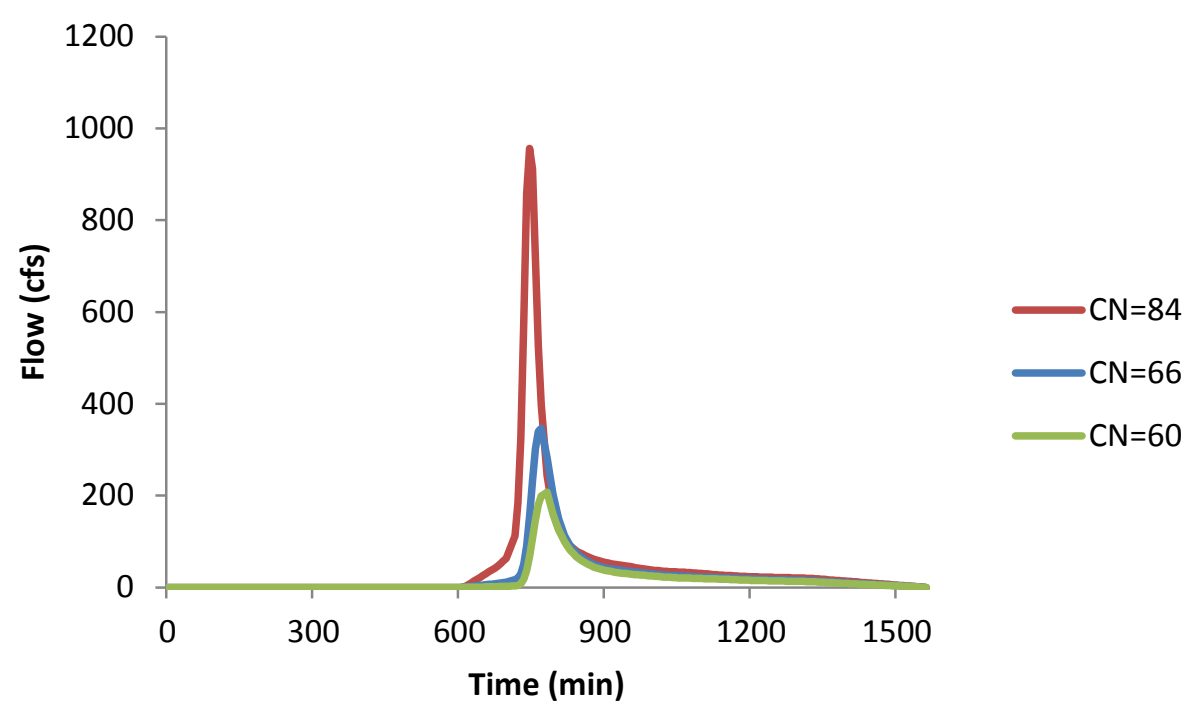

Figure 37: Storm response hydrograph for a 50-year storm at outlet 1C of retrofit design for varying $\mathrm{CN}$

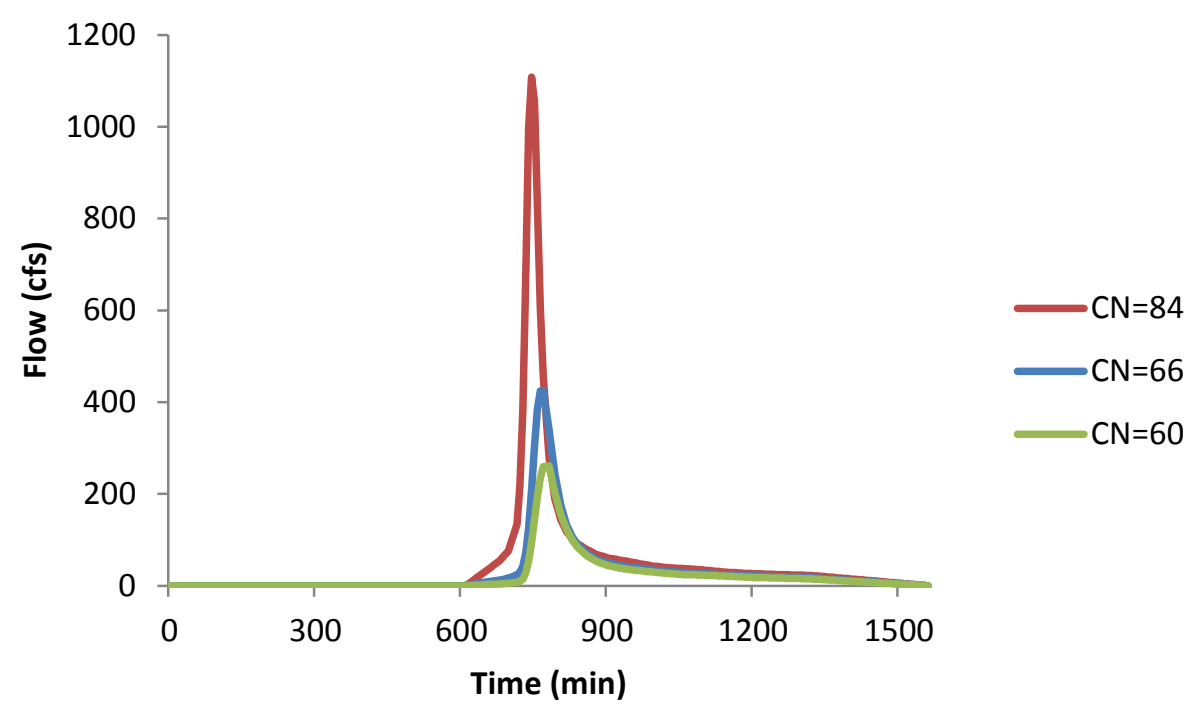

Figure 38: Storm response hydrograph for a 100 -year storm at outlet $1 \mathrm{C}$ of retrofit design for varying $\mathbf{C N}$ 


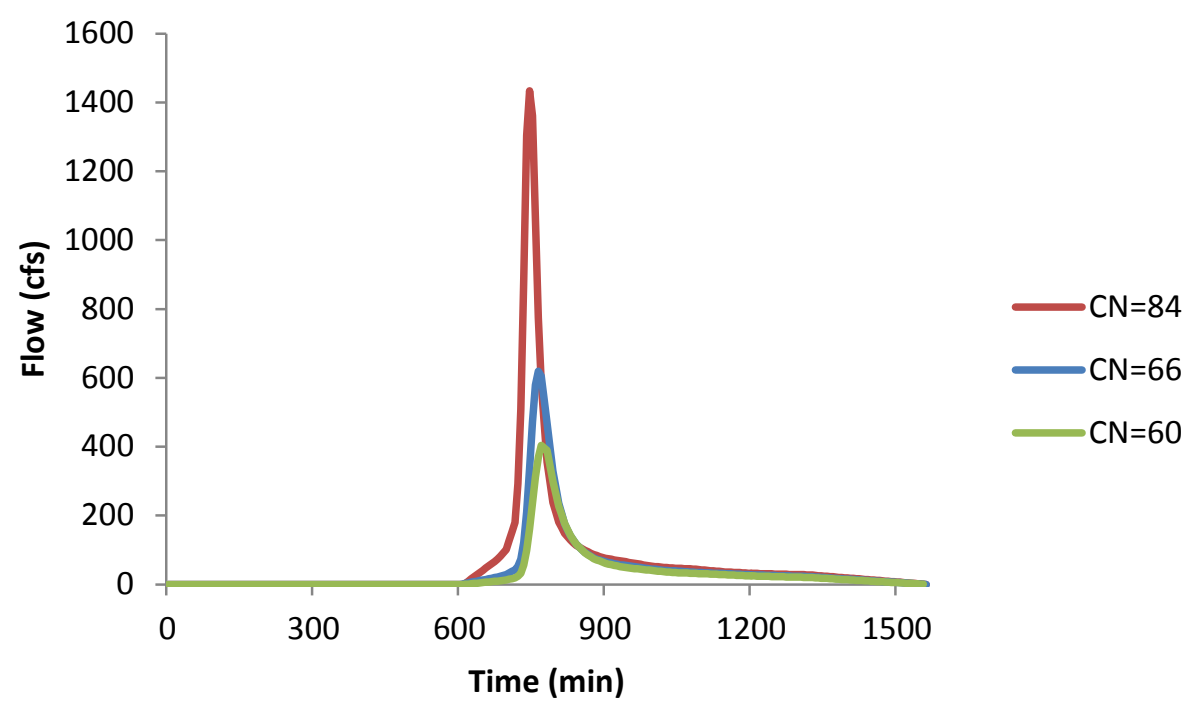

Figure 39: Storm response hydrograph for a 500-year storm at outlet $1 \mathrm{C}$ of retrofit design for varying $\mathrm{CN}$ 


\section{Appendix B: Percent Difference Between Reclamation Designs and Original Topography for 1 through 500-year Return Periods}

Table 41: Percent difference of peak discharge in comparison with the original topography at $\mathrm{CN}=66$

\begin{tabular}{|c|c|c|c|c|}
\hline $\begin{array}{c}\text { Return } \\
\text { period } \\
\text { (yrs) }\end{array}$ & $\begin{array}{c}\text { Time of } \\
\text { Reclamation }\end{array}$ & $\begin{array}{l}\text { GLD } \\
(\%)\end{array}$ & $\begin{array}{c}\text { Detention } \\
\text { (\%) }\end{array}$ & $\begin{array}{c}\text { Retrofit } \\
\text { (\%) }\end{array}$ \\
\hline \multirow{3}{*}{1} & $\mathrm{DM}$ & 870 & 720 & 390 \\
\hline & SR & 5 & -33 & -37 \\
\hline & LR & 5 & -83 & -85 \\
\hline \multirow{3}{*}{2} & $\mathrm{DM}$ & 560 & 450 & 230 \\
\hline & SR & 1 & -39 & -41 \\
\hline & LR & 1 & -81 & -82 \\
\hline \multirow{3}{*}{5} & $\mathrm{DM}$ & 320 & 246 & 112 \\
\hline & SR & -3 & -45 & -43 \\
\hline & LR & -3 & -76 & -76 \\
\hline \multirow{3}{*}{10} & $\mathrm{DM}$ & 240 & 180 & 73 \\
\hline & SR & -7 & -47 & -46 \\
\hline & LR & -7 & -73 & -72 \\
\hline \multirow{3}{*}{25} & $\overline{\mathrm{DM}}$ & 200 & 140 & 50 \\
\hline & SR & -7 & -47 & -48 \\
\hline & LR & -7 & -70 & -70 \\
\hline \multirow{3}{*}{50} & $\mathrm{DM}$ & 180 & 120 & 41 \\
\hline & SR & -7 & -48 & -49 \\
\hline & LR & -7 & -70 & -70 \\
\hline \multirow{3}{*}{100} & $\mathrm{DM}$ & 160 & 100 & 31 \\
\hline & SR & -6 & -48 & -50 \\
\hline & LR & -6 & -68 & -69 \\
\hline \multirow{3}{*}{500} & $\mathrm{DM}$ & 160 & 74 & 14 \\
\hline & SR & 10 & -50 & -51 \\
\hline & LR & 10 & -67 & -68 \\
\hline
\end{tabular}

Note: DM=during mining; $\mathrm{SR}=$ short-term reclaimed $(<5$ years $) ; \mathrm{LR}=$ long-term reclaimed $(>5$ years) 
Table 42: Percent difference of time of peak in comparison with the original topography at $\mathrm{CN}=66$

\begin{tabular}{|c|c|c|c|c|}
\hline $\begin{array}{c}\text { Return } \\
\text { period } \\
(y r s)\end{array}$ & $\begin{array}{c}\text { Time of } \\
\text { Reclamation }\end{array}$ & $\begin{array}{l}\text { GLD } \\
(\%)\end{array}$ & $\begin{array}{c}\text { Detention } \\
(\%)\end{array}$ & $\begin{array}{c}\text { Retrofit } \\
(\%)\end{array}$ \\
\hline \multirow{3}{*}{1} & $\mathrm{DM}$ & -1 & -2 & 1 \\
\hline & SR & 2 & 2 & 6 \\
\hline & LR & 2 & 5 & 7 \\
\hline \multirow{3}{*}{2} & $\mathrm{DM}$ & -1 & -2 & 1 \\
\hline & SR & 1 & 2 & 6 \\
\hline & LR & 1 & 3 & 4 \\
\hline \multirow{3}{*}{5} & $\mathrm{DM}$ & -1 & -2 & 1 \\
\hline & SR & 1 & 1 & 4 \\
\hline & $\mathrm{LR}$ & 1 & 3 & 6 \\
\hline \multirow{3}{*}{10} & $\mathrm{DM}$ & -1 & -2 & 1 \\
\hline & SR & 1 & 1 & 4 \\
\hline & LR & 1 & 2 & 6 \\
\hline \multirow{3}{*}{25} & $\mathrm{DM}$ & -1 & -2 & 1 \\
\hline & SR & 0 & 1 & 5 \\
\hline & LR & 0 & 2 & 6 \\
\hline \multirow{3}{*}{50} & $\mathrm{DM}$ & -1 & -2 & 1 \\
\hline & SR & 0 & 1 & 5 \\
\hline & LR & 0 & 2 & 6 \\
\hline \multirow{3}{*}{100} & $\mathrm{DM}$ & -1 & -2 & 1 \\
\hline & SR & 0 & 1 & 5 \\
\hline & LR & 0 & 2 & 6 \\
\hline \multirow{3}{*}{500} & $\mathrm{DM}$ & -2 & -2 & 1 \\
\hline & SR & -1 & 1 & 4 \\
\hline & LR & -1 & 2 & 4 \\
\hline
\end{tabular}


Table 43: Percent difference of total runoff volume in comparison with the original topography at $\mathrm{CN}=66$

\begin{tabular}{|c|c|c|c|c|}
\hline $\begin{array}{l}\text { Return } \\
\text { period } \\
(\mathrm{yrs})\end{array}$ & $\begin{array}{c}\text { Time of } \\
\text { Reclamation }\end{array}$ & GLD & Detention & Retrofit \\
\hline \multirow{3}{*}{1} & $\mathrm{DM}$ & 0 & 2 & 160 \\
\hline & SR & 11 & -3 & -28 \\
\hline & LR & 11 & -50 & -68 \\
\hline \multirow{3}{*}{2} & $\mathrm{DM}$ & 0 & 2 & 110 \\
\hline & SR & 9 & -8 & -29 \\
\hline & LR & 9 & -49 & -63 \\
\hline \multirow{3}{*}{5} & $\mathrm{DM}$ & 0 & 3 & 65 \\
\hline & SR & 7 & -15 & -30 \\
\hline & LR & 7 & -46 & -57 \\
\hline \multirow{3}{*}{10} & $\mathrm{DM}$ & 0 & 3 & 44 \\
\hline & SR & 6 & -17 & -30 \\
\hline & LR & 6 & -44 & -53 \\
\hline \multirow{3}{*}{25} & DM & 0 & 3 & 31 \\
\hline & SR & 5 & -18 & -31 \\
\hline & LR & 5 & -42 & -51 \\
\hline \multirow{3}{*}{50} & $\mathrm{DM}$ & 0 & 3 & 26 \\
\hline & SR & 5 & -19 & -30 \\
\hline & LR & 5 & -41 & -50 \\
\hline \multirow{3}{*}{100} & $\mathrm{DM}$ & 0 & 3 & 19 \\
\hline & SR & 5 & -19 & -31 \\
\hline & LR & 5 & -40 & -48 \\
\hline \multirow{3}{*}{500} & $\mathrm{DM}$ & 1 & 3 & 8 \\
\hline & SR & 5 & -21 & -31 \\
\hline & LR & 5 & -38 & -46 \\
\hline
\end{tabular}

Note: DM=during mining; SR = short-term reclaimed ( $<5$ years); LR = long-term reclaimed $(>5$ years) 
Table 44: Percent difference of peak discharge in comparison with the original topography at $\mathbf{C N}=\mathbf{8 4}$

\begin{tabular}{|c|c|c|c|c|}
\hline $\begin{array}{c}\text { Return } \\
\text { period } \\
\text { (yrs) }\end{array}$ & $\begin{array}{c}\text { Time of } \\
\text { Reclamation }\end{array}$ & $\begin{array}{l}\text { GLD } \\
(\%)\end{array}$ & $\begin{array}{c}\text { Detention } \\
(\%)\end{array}$ & $\begin{array}{c}\text { Retrofit } \\
\text { (\%) }\end{array}$ \\
\hline \multirow{3}{*}{1} & $\mathrm{DM}$ & -11 & -25 & -55 \\
\hline & SR & -90 & -94 & -94 \\
\hline & LR & -90 & -99 & -99 \\
\hline \multirow{3}{*}{2} & $\mathrm{DM}$ & -11 & -26 & -55 \\
\hline & SR & -86 & -92 & -92 \\
\hline & LR & -86 & -97 & -98 \\
\hline \multirow{3}{*}{5} & $\mathrm{DM}$ & -11 & -27 & -55 \\
\hline & SR & -80 & -88 & -88 \\
\hline & LR & -80 & -95 & -95 \\
\hline \multirow{3}{*}{10} & $\mathrm{DM}$ & -11 & -28 & -55 \\
\hline & SR & -76 & -86 & -86 \\
\hline & LR & -76 & -93 & -93 \\
\hline \multirow{3}{*}{25} & DM & -11 & -29 & -55 \\
\hline & SR & -72 & -84 & -85 \\
\hline & LR & -72 & -91 & -91 \\
\hline \multirow{3}{*}{50} & $\mathrm{DM}$ & -11 & -30 & -55 \\
\hline & SR & -70 & -83 & -84 \\
\hline & LR & -70 & -90 & -90 \\
\hline \multirow{3}{*}{100} & $\mathrm{DM}$ & -11 & -30 & -55 \\
\hline & SR & -68 & -82 & -83 \\
\hline & LR & -68 & -89 & -89 \\
\hline \multirow{3}{*}{500} & $\mathrm{DM}$ & 1 & -32 & -55 \\
\hline & SR & -57 & -81 & -81 \\
\hline & LR & -57 & -87 & -87 \\
\hline
\end{tabular}

Note: DM=during mining; $\mathrm{SR}=$ short-term reclaimed $(<5$ years $)$; $\mathrm{LR}=$ long-term reclaimed $(>5$ years) 
Table 45: Percent difference of time of peak in comparison with the original topography at $\mathrm{CN}=\mathbf{8 4}$

\begin{tabular}{|c|c|c|c|c|}
\hline $\begin{array}{c}\text { Return } \\
\text { period } \\
\text { (yrs) }\end{array}$ & $\begin{array}{c}\text { Time of } \\
\text { Reclamation }\end{array}$ & $\begin{array}{l}\text { GLD } \\
(\%)\end{array}$ & $\begin{array}{c}\text { Detention } \\
(\%)\end{array}$ & $\begin{array}{c}\text { Retrofit } \\
\text { (\%) }\end{array}$ \\
\hline \multirow{3}{*}{1} & $\mathrm{DM}$ & 1 & 0 & 2 \\
\hline & SR & 3 & 4 & 7 \\
\hline & LR & 3 & 7 & 9 \\
\hline \multirow{3}{*}{2} & DM & 1 & 0 & 2 \\
\hline & SR & 2 & 3 & 6 \\
\hline & LR & 2 & 5 & 7 \\
\hline \multirow{3}{*}{5} & $\mathrm{DM}$ & 1 & 0 & 2 \\
\hline & SR & 2 & 3 & 6 \\
\hline & LR & 2 & 5 & 7 \\
\hline \multirow{3}{*}{10} & DM & 1 & 0 & 2 \\
\hline & SR & 2 & 3 & 6 \\
\hline & LR & 2 & 4 & 7 \\
\hline \multirow{3}{*}{25} & $\mathrm{DM}$ & 1 & 0 & 2 \\
\hline & SR & 2 & 3 & 6 \\
\hline & LR & 2 & 4 & 7 \\
\hline \multirow{3}{*}{50} & $\mathrm{DM}$ & 1 & 0 & 2 \\
\hline & SR & 2 & 3 & 6 \\
\hline & LR & 2 & 4 & 7 \\
\hline \multirow{3}{*}{100} & $\mathrm{DM}$ & 1 & 0 & 2 \\
\hline & SR & 2 & 3 & 6 \\
\hline & LR & 2 & 4 & 7 \\
\hline \multirow{3}{*}{500} & $\mathrm{DM}$ & 0 & -1 & 3 \\
\hline & SR & 1 & 2 & 5 \\
\hline & LR & 1 & 4 & 6 \\
\hline
\end{tabular}

Note: DM=during mining; $\mathrm{SR}=$ short-term reclaimed $(<5$ years $) ; \mathrm{LR}=$ long-term reclaimed $(>5$ years) 
Table 46: Percent difference of total runoff volume in comparison with the original topography at $\mathrm{CN}=84$

\begin{tabular}{|c|c|c|c|c|}
\hline $\begin{array}{l}\text { Return } \\
\text { period } \\
(\mathrm{yrs})\end{array}$ & $\begin{array}{c}\text { Time of } \\
\text { Reclamation }\end{array}$ & GLD & Detention & Retrofit \\
\hline \multirow{3}{*}{1} & $\mathrm{DM}$ & 0 & 2 & -34 \\
\hline & SR & -71 & -75 & -81 \\
\hline & LR & -71 & -87 & -92 \\
\hline \multirow{3}{*}{2} & DM & 0 & 2 & -34 \\
\hline & SR & -66 & -71 & -78 \\
\hline & LR & -66 & -84 & -89 \\
\hline \multirow{3}{*}{5} & $\mathrm{DM}$ & 0 & 3 & -34 \\
\hline & SR & -57 & -66 & -72 \\
\hline & LR & -57 & -78 & -83 \\
\hline \multirow{3}{*}{10} & $\mathrm{DM}$ & 0 & 3 & -34 \\
\hline & SR & -52 & -62 & -68 \\
\hline & LR & -52 & -75 & -79 \\
\hline \multirow{3}{*}{25} & DM & 0 & 3 & -34 \\
\hline & SR & -47 & -59 & -65 \\
\hline & LR & -47 & -71 & -75 \\
\hline \multirow{3}{*}{50} & $\mathrm{DM}$ & 0 & 3 & -34 \\
\hline & SR & -45 & -57 & -63 \\
\hline & LR & -45 & -69 & -74 \\
\hline \multirow{3}{*}{100} & $\mathrm{DM}$ & 0 & 3 & -34 \\
\hline & SR & -42 & -55 & -62 \\
\hline & LR & -42 & -67 & -71 \\
\hline \multirow{3}{*}{500} & $\mathrm{DM}$ & 1 & 3 & -34 \\
\hline & SR & -36 & -52 & -58 \\
\hline & LR & -36 & -63 & -67 \\
\hline
\end{tabular}

Note: DM=during mining; SR = short-term reclaimed ( $<5$ years); LR = long-term reclaimed $(>5$ years) 